\title{
DE CHARADAS E ADIVINHAS: O CONTINUUM do CONTAR EM ANGELA LAGO
}




\section{DE CHARADAS E ADIVINHAS: o CONTINUUM DO CONTAR \\ $\mathrm{DE}$ ANGELA LAGO}

Dissertação de Mestrado apresentada ao Departamento de Letras Clássicas e Vernáculas da Faculdade de Filosofia, Letras e Ciências Humanas da Universidade de São Paulo. Área: Estudos Comparados de Literaturas de Língua Portuguesa. Orientadora: Prof. $^{a}$ Dr. ${ }^{a}$ Maria dos Prazeres Santos Mendes. 
Pág.

$\begin{array}{ll}\text { INTRODUÇÃO } & 01\end{array}$

CAPÍTULO 1 - O OLHAR E O CONTAR - UM EXERCÍCIO LÚDICO 06 EM CHARADAS MACABRAS

1.1. O caminho inverso - do atual ao primordial 06

1.2. Tradição oral em presença $\quad 16$

1.3. A importância do jogar 20

1.4. Na esfera da ação $\quad 22$

1.5. O tradicional em fusão com o atual 24

1.6. O embrenhar entre texto verbal e texto visual 28

Relação de Pranchas $\quad 47$

CAPÍTULO 2 - DA ORALIDADE AO RECONTAR DOS TEMPOS 48 MODERNOS EM SUA ALTEZA A DIVINHA

2.1. Uma aventura no tempo $\quad 48$

2.2. O lúdico no adivinhar $\quad 54$

2.3. Oralidade como linguagem $\quad 58$

$\begin{array}{ll}\text { 2.4. Os olhos que vêem } & 70\end{array}$

2.5. Formas manifestas do riso

2.6. A improvisação como recurso: de tolo a herói 82

2.7. Pelos veios da cultura medieval $\quad 85$

Relação de Pranchas 102

CAPÍTULO 3 - A PRAÇA, O PALCO, A ARTE NO ENREDAR DE 10103 ADIVINHAS PICANTES

3.1. A expressão em texto verbal 103

3.2. Pegadas do tempo 105

3.3. Praça-palco-livro 106

3.4. O recontar pela ilustração 109

$\begin{array}{ll}\text { Relação de Pranchas } & 118\end{array}$ 

AONDE BUSCAR NÃO SEI O QUÊ

4.1. O continuum do contar

4.2. Nas trilhas da cultura medieval

4.3. Brincando de imaginar

123

4.4. Dos meandros do conto popular ao sabor da expectativa às avessas

124

4.5. O visual e a estória

129

4.6. Final Feliz ?

135

Relação de Pranchas

CONCLUSÃO

139

BIBLIOGRAFIA

146 


\section{AGRADECIMENTOS}

À Maria dos Prazeres Santos Mendes, pelo olhar sempre carinhoso e atento, conduzindo-nos a valiosas descobertas

À Angela Lago, sensibilidade à flor da pele : compreensão e incentivo, desde os primeiros passos.

À Maria Lúcia P. S. Góes pelo nortear de caminhos.

À Maria José Palo pelas sugestões recebidas no Exame de Qualificação.

À Capes, pela bolsa de estudos que possibilitou o desenvolvimento dessa pesquisa.

A Pedro e Helena, nossos pais : amor e dedicação desde sempre.

À Margarete, nossa irmã, pela colaboração espontânea.

A Vergilio: companheiro incansável de muitas jornadas.

À Bruna e Camila: nossa fonte de inocência e inspiração.

À Rita, amiga-irmã de tantos caminhos cruzados.

À Vida: por nos presentear com a História. 
"A verdadeira viagem de descoberta consiste não em procurar novas paragens, mas em ter novos olhos."

Marcel Proust

"Toda obra de arte é filha de seu tempo e, muitas vezes, mãe de nossos sentimentos."

Wassily Kandinsky 


\section{Para nossas filhas, Bruna e Camila}

De perguntas "sem pé nem cabeça" a palavras inventadas - a construção de um mundo de verdade. 
e

stabelecemos como objetivo de nossa pesquisa: o descortinar do olhar para obras de Literatura Infanto-Juvenil, viabilizado por meio do entrelaçamento de aspectos referentes ao imaginário medieval ao fazer literário de Angela Lago.

Destacamos em Charadas Macabras, a presença do elemento capeta como veiculador de informação e ou transformação através do uso da palavra.

Em Sua Alteza A Divinha, o resgate da oralidade, enfocada sob a luz da teoria bakhtiniana, concedeu a ampliação de recursos como a comicidade, a ludicidade, a brincadeira, encapsulada na obra através do jogo, do desafio oral englobados na esfera da antítese social - o popular contrapondo-se à aristocracia, o forte contra o fraco - o elemento feminino em oposição ao masculino, fatores que concorreram para o dimensionar da análise.

Caminhar nas trilhas da cultura oral possibilitou, ainda, a descoberta do riso espontâneo pelos veios da improvisação, pelo evidenciar da praça pública com suas práticas, identificadas em 10 Adivinhas Picantes, além de contribuir para o despertar da literatura paródica, presente em Indo Não Sei Aonde Buscar Não Sei O Quê.

A busca de releituras do conto da princesa “expert” em adivinhações, compiladas por pesquisadores como Adolpho Coelho e Câmara Cascudo consolidaram, sobremaneira, o propósito inicial de pesquisa - a comprovação, nos contos de Angela Lago, da influência da cultura medieval que chega, através de Portugal e Brasil.

Na conclusão, retomamos os elementos pertinentes à cada obra permeados ao âmbito do leitor, e palmilhados, particularmente, ao universo da criança - quintal da casa do faz-de-conta, lugar onde a magia, a alegria e o sonho, são. 
We have widely discussed, in this written work, about different understanding points of Literature books for children, pointing out the influence of medieval imaginary in Angela Lago’s masterpiece.

In the book Charadas Macabras, we have elicited the presence of the Devil, by the transformation of his spoken words.

The oral exercise, in the narrative Sua Alteza A Divinha, was focused under the lights of Bakhtin's concepts. The aspects of theses concepts took into consideration the amplifying of the comic and the children's entertainment points, which were encapsulated in the tale by the game, (the oral contest). All these points should be understood as a social anthitesis - the popular level put in front of the aristocracy, strong people against weak people - the feminine element against masculine element. All these factors contributed toward the dimensional views of the this book.

In researching, "the study of oral culture" we discovered it contained espontaneous humor cause by the improvise performances, present in the public square. The public square was a popular place for people to hold their artistic performance. These aspects can be identified in the books Indo Não Sei Aonde Buscar Não Sei O Quê and 10 Adivinhas Picantes.

Upon examining the "tales of a princess" we found they contain many expertly written riddles. This subject was widely studied by researchers like Adolpho Coelho and Câmara Cascudo, who also empathized the initial purpose of this project - the 
corroboration of the influence of medieval culture, by Portugal and Brazil, in Angela Lago’s tales.

In conclusion, we have taken the elements that belong to each narrative and inserted them into the sphere of the reader, and particulary, the child reader. The mind of child is known to be most criative and imaginative. It's a world where invention, dreams, magic, hapiness and sadness exists. 
“Designa-se pela palavra Litteratura, no sentido lato, todo o complexo de manifestações do espírito humano, tendo por orgão a palavra (e especialmente a palavra fixada pela escripta), cujo fim não é meramente utilitário e individual.”

Adolpho F. Coelho

\section{g}

ostaríamos de demonstrar, nessa pesquisa, que literatura se faz, como argumenta Coelho, com a palavra, com a voz do povo que pode sonhar através do contar, não somente pelo ato da escrita, estando a criação literária alicerçada em outros códigos de linguagem. Ao lado da computação gráfica, que não será, nesta oportunidade estudada, do jogo cromático, do próprio livro como canal de comunicação, está o recurso visual que pode complementar ou extrapolar o verbal ou ainda estabelecer uma relação imagem-texto, instrumento que permite ao leitor e mais especificamente ao leitor infantil, interagir com a obra “... via criatividade e imaginação ...”1 Palo e Oliveira apud Mendes salientam que:

\footnotetext{
${ }^{1}$ MENDES, Maria dos Prazeres S. Monteiro Lobato, Clarice Lispector, Lygia Bojunga Nunes: O Estético em Diálogo Na Literatura Infanto-Juvenil. Tese apresentada à Comissão Julgadora da Pontifícia Universidade Católica de São Paulo. São Paulo, 1994, p.7.
} 
“O pensamento infantil é aquele que está sintonizado com esse pulsar pelas vias do imaginário. E é justamente nisso que os projetos mais arrojados de literatura infantil investem, não escamoteando o literário, nem o facilitando, mas enfren-tando sua qualidade artística e oferecendo os melhores produtos possíveis ao repertório infantil, que tem a competência necessária para traduzí-lo pelo desempenho de uma leitura múltipla e diversificada. Leitura que segue trilhas, lança hipóteses, experimenta, duvida, num exercício contínuo de experiementação e descoberta. Como a vida., ${ }^{2}$

O aventurar, pelas vias do imaginário medieval, e o reconhecer, na ficção de Angela Lago, notadamente nas obras Charadas Macabras, Sua Alteza A Divinha, 10 Adivinhas Picantes e Indo Não Sei Aonde Buscar Não Sei $O$ Quê, as influências que a tradição oral exerce sobre as obras, implica descoberta prazerosa de raízes - ampliação de horizontes, identificação e exploração de elementos relacionados à figura simbólica do Demônio, contextualizado em seu grau de interpretabilidade - do âmbito do medieval à modernidade. Ainda nesse segmento, a exploração, em cotejamento, dos significados relacionados ao demônio, presentes na narrativa $O$ Gênio e a Garrafa e a representação do capeta em Charadas Macabras, faz-se importante como ponto de enriquecimento da análise.

A analogia entre as enigmáticas danças macabras, prática medieval realizada em cemitérios, que objetivava o ludibriar da morte, e as charadas, denominadas macabras, que deslizam pelas páginas de Charadas Macabras a partir da sala escura do necrotério... será igualmente abordada

\footnotetext{
${ }^{2}$ MENDES, Maria dos Prazeres S. O Estético em Diálogo na Literatura Infanto-Juvenil. Tese apresentada à Comissão Julgadora da Pontifícia Universidade Católica de São Paulo. São Paulo, 1994, p.8.
} 
com o intuito de enfatizar a presença do medievalismo na vida do homem moderno.

Dentro da cultura cômica popular destacaremos a figura representativa do homem simplório, vulgarmente adjetivado de tolo, bobo ou pícaro (este último em Portugal e Espanha no século XV), e seu humorismo irreverente, elementos que caracterizam Sua Alteza A Divinha, Indo Não Sei Aonde Buscar Não Sei O Quê e 10 Adivinhas Picantes e Charadas Macabras (esta última na figura do Capeta), fatores que despertam o interesse do leitor que, em cumplicidade com as personagens, interconecta-se com este conteúdo informativo-lúdico. Pelo elo da literatura paródica, o narrador introjeta o tolo na esfera do leitor e este adentra ao universo do tolo, rindo de suas peripécias, apoiando a personagem no seu propósito e quando, pela incorporação da forma do tolo, desperta para a importância do espírito popular na obra e, aqui fazemos parênteses - a importância da obra para a Literatura Infanto-Juvenil, através do resgate da linguagem oral, do reavivar das adivinhas que põe em jogo as forças do conhecimento, a vida do interrogado, dos costumes e brincadeiras que são facilmente identificadas pelo leitor, que as reconhece como elementos inseridos dentro de seu tempo.

Jolles afirma: “ Não poder resolver uma adivinha é morrer; apresentar uma adivinha que ninguém resolve é viver.”3 Este será o fio da tessitura narrativa em Sua Alteza A Divinha e Charadas Macabras - decifrar a charada significa viver, ou melhor, encontrar a saída do cemitério e livrar-se da influência do capeta. A resolução das adivinhas representa a ascensão - de tolo a herói - e implica isenção da forca.

\footnotetext{
${ }^{3}$ JOLLES, André. Formas Simples. Trad. Álvaro Cabral. São Paulo, Cultrix, 1976, p.114.
} 
A presença do jogo, permeado pelo desafio proposto pelos contos analisados, convida o leitor a participar ativamente do enredo, ora tomando parte como decifrador de charadas no cemitério, ora ovacionando Louva-adeus pela inventividade, em Sua Alteza Adivinha, ou ainda apostando no sucesso de Seinão, na sua aventura até o inferno.

Nesse cruzamento, porém, entre o contexto medieval, permeado pelo riso, e as releituras de Angela Lago utilizaremos, como instrumental teórico, os conceitos de Bergson sobre a classificatória elaborada por Propp sobre a ação das personagens no conto maravilhoso, mais acentuadamente em Sua Alteza A Divinha e Indo Não Sei Aonde Buscar Não Sei O Quê, quando traçaremos o perfil da personagem protagonista e seu trajeto dentro da narrativa, aspecto que o qualifica como herói.

Apoiados em Todorov, no tocante à teoria sobre o gênero fantástico e o maravilhoso, iremos analisar Charadas Macabras e inseri-la em um dos gêneros apresentados. Para a análise do texto visual, ainda na mesma obra, servir-nos-emos dos estudos a respeito de metalinguagem elaborados por Jackbson.

Elucidaremos, por fim, a presença de um perfil histórico em nosso projeto, principalmente de elementos relacionados à cultura popular na Idade Média, aspecto que propiciará uma maior compreensão das obras a serem analisadas. Servirão de ferramenta, para esse intento, obras de autores tais como: Gilson, Eliade, Ariés, Delumeau, Franco Júnior, Boucier, Goff.

Dos conceitos sobre a cultura cômica popular, referente ao período medieval, esmiuçados por Bakhtin, iremos subtrair a importância da praça pública como referencial de interação do povo - valorização do contar, do improvisar, do parodiar, do riso que, 
“... ocupou significativo espaço nos ritos, festividades, espetáculos, formas literárias e expressões provenientes de esferas não-oficiais, proporcionando visão de mundo, dos homens e das relações humanas diferentes daquelas propostas pela Igreja e pelo Estado (......”,

características que podem ser constatadas, particularmente em Sua Alteza A Divinha, 10 Adivinhas Picantes e Indo Não Sei Aonde Buscar Não Sei O Quê.

Essa pesquisa também estará estruturada na proposta de Jolles no que se refere ao conto na sua forma simples, ou seja, produção coletiva, popular, sem especificação espaço-temporal; aquela que pertence ao universo do contador de estórias que, seguidamente, leva a sua experiência, o seu conhecimento, a diferentes paragens. Ao inserirmos em nosso trabalho, os conceitos de Jolles visamos à comprovação da fusão entre a forma simples, marcada pela oralidade, e a forma artística, reelaborada por Angela Lago, acrescida de inventividade e modernidade.

Os conceitos semióticos peirceanos que apontam caminhos e dilatam o olhar para tantas descobertas, serão utilizados neste estudo, especificamente no que se refere ao diagrama e aos interpretantes, quando se fizer necessário exemplificar a importância da tessitura sígnica na obra.

Como procedimento final, iremos examinar como se dá a função do tolo em algumas variantes do conto da princesa que gostava de fazer adivinhas, dentre elas, aquelas cujo resgate pertence à cultura portuguesa, compiladas graças à extensa pesquisa de folcloristas como Cascudo, Romero, Coelho e Braga, fonte de onde pudemos subtrair as releituras.

\footnotetext{
${ }^{4}$ MACEDO, José Rivair. Riso, Cultura e Sociedade na Idade Média. São Paulo, Unesp, 2000, p.100.
} 


\section{Capítulo 1 O OLHAR E O CONTAR - UM EXERCÍCIO \\ LÚDICO EM CHARADAS MACABRAS}

“O homem aprende através dos sentidos. A capacidade de ver, sentir, ouvir, cheirar e provar proporciona os meios pelos quais se realiza uma interação do homem com seu meio.”

Lowenfeld e Brittain

\subsection{Caminho Inverso: do atual ao primordial}

\section{A exploração de elementos que justifiquem a presença de uma} perceptível articulação entre a narrativa, no ato de contar e recontar, buscando, no escavar dos tempos sombrios da Idade Média, rituais e práticas popularmente denominadas macabras, pode tornar esta análise fecunda no sentido de enfatizar a contribuição de Charadas Macabras de Angela Lago para a Literatura Infanto-juvenil.

O tipo de sociedade predominante na Idade Média, sobretudo entre os séculos XI e XV, era a feudo-clerical. Composta pela aristocracia e legitimada pela Igreja, responsável pelo modelo ideológico do sistema vigente na época, liderava uma comunidade socialmente desigual, formada pela 
preponderância masculina - homens guerreiros, de um lado, e mulheres marginalizadas, de outro, cabendo-lhes a submissão servil. A proposta ideológica formulada pelo bispo Adalberon de Laon, aproximadamente entre 1025 e 1027 pregava:

“a cidade de Deus, que parece una, é tripla. Alguns rezam, outros combatem e outros trabalham. Os três vivem juntos e não se separam: os serviços de um permitem os trabalhos de outras duas e cada qual, por sua vez, presta apoio às outras”. 1

Claramente expressa pelo fragmento acima, a defesa dos interesses econômicos e sociais, ditada pelo Feudo-Clericalismo, entendida como prioridade, visava ao equilíbrio e à prosperidade do Estado. Para tanto, estabeleciam-se funções,

“... uma divisão social do trabalho: os oratores eram os responsáveis pela salvação espiritual de toda a sociedade, protegendo-a com as armas da fé dos poderes malignos do Além; os bellatores com armas materiais estavam encarregados de defender a sociedade de seus inimigos terrenos; os laboratores, vistos pelos pensadores eclesiásticos naquele mundo essencialmente agrário como camponeses, estavam incumbidos da produção e portanto do sustento das demais camadas sociais, como forma de resgatar o pecado original."2

\footnotetext{
${ }^{1}$ ADALBERTO DE LAON apud FRANCO, Hilário Júnior in Peregrinos, Monges e Guerreiros. Feudo - Clericalismo e Religiosidade em Castela Medieval. São Paulo, Hucitec, 1990, p.28.

${ }^{2}$ FRANCO, Hilário Júnior. Peregrinos, Monges e Guerreiros. Feudo-Clericalismo e Religiosidade em Castela Medieval. São Paulo, Hucitec, 1990, p.29.
} 
Existia, portanto, uma articulação entre os três pólos que margeava a mentalidade medieval.

\begin{abstract}
"De um lado, a belicosidade era uma atitude mental básica naquela sociedade militar, fosse pela participação humana (clero) no conflito cósmico entre forças do Bem e do Mal, fosse para enfrentar (guerreiros) as invasões pagãs e muçulmanas, aliás expressões daquele mundo maléfico. Esse traço mental estava vinculado a outro, a contratualidade, que ligava homem-Deus (via clero) e homem-homem (via relação de doação-proteção).” ${ }^{3}$
\end{abstract}

Mas, apesar da relutância da Igreja, em projetar na sociedade os dogmas cristãos, impondo e reafirmando a existência de uma religiosidade, cultivaram-se na sociedade medieval, durante séculos e ainda hoje (século XXI), cultivam-se práticas de rituais sagrados, endereçados às bruxas, fadas, gnomos, etc, comportamento que atesta a presença da cultura milenar enfronhada na alma humana. É, então, modelar a citação de Gilson, ${ }^{4}$ quando se refere à posição psico-intelectiva do indivíduo socialmente inserido em dado grupo, independente da época em que se situa:

“... o universo em que estamos mergulhados desde o nosso nascimento não é apenas o da sensação; também é definido pela representação dele que nossa época e nosso

\footnotetext{
${ }^{3}$ FRANCO, Hilário Júnior. Peregrinos, Monges e Guerreiros. Feudo-clericalismo, Religiosidade em Castela Medieval. p.31.

${ }^{4}$ GILSON, Etienne. A Filosofia na Idade Média .Trad. Eduardo Brandão. São Paulo, Martins Fontes,1998, p. 942.
} 
meio tendem a nos impor. O homem do século $\mathrm{XX}$ não nasce no mesmo mundo que o homem do século XII, e nascer no século XII cristão ou no século XII hindu era nascer em dois universos diferentes. Por mais livre que possa ser um pensamento filosófico e por mais profunda que deva ser a marca por ele deixada na superfície das coisas, ele sempre começa, pois, por um ato de submissão; ele se move livremente, mas dentro de um mundo dado.”

O aspecto hierofânico igualmente traça o perfil da mentalidade medieval. Os fenômenos naturais de toda ordem - cerimônias e festas cujo tema principal era renovação (ciclo de semeadura, nascimento, vida e morte) eram entendidos como manifestação do sagrado. "O simbolismo era a linguagem mais adequada ao medievo em função de suas estruturas mentais e culturais." 5

Aproveitando-se dessa tendência do homem medieval, ao maravilhoso, à pré disposição inconsciente ao símbolo - viagens ao Além, sonhos, o Clero propunha o culto à Virgem, por exemplo, em substituição à devoção às divindades agrárias. A figura do anjo consistia em outro aliado do homem na luta contra as forças maléficas, assim como o emprego de palavras e gestos ( sinal-da-cruz e orações) considerados eficazes na proteção pessoal de cada um.

Dentro desse contexto, entendido como uma tentativa reiterada de suplantação das crenças pagãs pela Igreja, impondo uma forma dogmática ao cristianismo, não se obteve o êxito esperado, pelos menos no período entre o século XI ao XIII, quanto à “purificação das almas”, pois a mentalidade coletiva, atrelada a costumes de outros tempos, não conseguia se libertar de

\footnotetext{
${ }^{5}$ GILSON, Etienne. A Filosofia na Idade Média. p.44.
} 
conceitos que norteavam suas mentes, principalmente os relacionados às questões da vida e da morte. "Na mentalidade coletiva, muitas vezes a vida e a morte não apareciam separadas por um corte nítido.”6

Acreditava-se, por exemplo, que os mortos compareciam, durante algum tempo, aos lugares de origem, habitavam suas antigas casas e mantinham a rotina anteriormente rompida. Segundo Jensen, o morto por afogamento, queda de árvores, atacado por animais selvagens ou vítima do parto mal sucedido, seria considerado o verdadeiro fantasma - “... se trata de un individuo marcado por el destino, del que la comunidad se aparta con horror y al que le esta denegado la entrada en el reino de los muertos."7 Havia, contudo, uma escala hierárquica que classificava os defuntos segundo suas obras. De acordo com a herança que o defunto deixava, este tinha direitos e poderes sobre os vivos. "O morto agarra o vivo", , dizia o ditado popular.

\begin{abstract}
"Mas o morto podia agarrar o vivo de uma outra maneira. As danças macabras punham em cena o invencível esqueleto que arrasta à força para sua ronda fúnebre pessoas de qualquer idade e qualquer condição.” 9
\end{abstract}

A dança, compondo o arsenal de práticas, vinculada à religiosidade popular, transcende ao tempo. Presente nas diferentes comunidades, a dança, com a devida referência à sua importância, caracteriza-se como um substrato

\footnotetext{
${ }^{6}$ DELUMEAU, Jean. História do Medo no Ocidente. Trad. Maria L. Machado. São Paulo, Companhia das Letras, 1993, p.84.

${ }^{7}$ JENSEN, Ad. E. Mito y culto entre pueblos primitivos. Trad. Carlos Gerhart. 3.ed. México, Fundo de Cultura Economica, 1986, p.366.

${ }^{8}$ DELUMEAU, Jean, op. cit., p.85.

${ }^{9}$ DELUMEAU, Jean, loc. cit.
} 
resgatado pela narrativa, entendido como manifestação artístico-religiosa, pertinente à Idade Média Central.

Na visão grega, os movimentos corporais ritmados eram de essência religiosa e “... um meio excelente de ser agradável aos deuses e de honrá-los."10 Em diversos momentos, considerados importantes, a dança também intervinha na sociedade grega: nascimento, pós-parto, núpcias, banquetes e morte.

O hábito da dança, na Idade Média, mais notadamente o de cunho religioso, consiste em herança popular pagã que persistiu até o século XV, embora a pouca disposição das autoridades eclesiásticas, em tolerar essa prática, já que a intenção era trazer os fiéis para o seio do Cristianismo puro, desprezando tudo que fosse contrário às bases fundamentais da Igreja. Dançavase a "chorea" ou a carola, durante as missas - uma dança de roda em que os participantes davam-se as mãos e, juntos, faziam passos ligeiros e saltitantes, sem contudo desmanchar a roda. Este tipo de dança circular, praticado inicialmente pela classe minoritária, foi posteriormente adotado pela nobreza, como fonte de espetáculo, por feiticeiras, em rituais iniciáticos, por tribos indígenas, em ocasiões solenes, etc.

Em Charadas Macabras, não ocorre propriamente uma dança de roda, mas uma interligação entre leitor, narrador e personagens. A proposição e tentativa de decifração das charadas pode ser classificada como circular, do ponto de vista do fluxo narrativo, mas também propõe a dança de roda. Constata-se, através de fragmentos do texto: "Tome fôlego. Pense mais um pouco (...) você sabe que tem algo a ser decifrado nesta porta?"11, o apelo contínuo do narrador, açulando o leitor a decifrar as charadas.

\footnotetext{
${ }^{10}$ PLATÃO apud BOUCIER, Paul. A História da Dança no Ocidente. São Paulo, Martins Fontes, 1987, p.22.

${ }^{11}$ LAGO, Angela. Charadas Macabras. Belo Horizonte, Formato, 1994, p.5.
} 
A partir do século XIV, desencadeia-se, na sociedade feudal, uma série de crises: econômica, militar e a perda de domínio da Igreja sobre o Estado. A Guerra dos Cem Anos tem início em 1337 e representa um período de flagelo para a povo, de maioria camponesa. Associada à guerra e à fome já existentes, a peste, identificada segundo a crença popular, “... como uma nuvem devoradora vinda do estrangeiro ...”12 chega a dizimar um terço da população. A morte, então, passa a figurar em rostos marcados pela dor. Neste cenário, as transformações são igualmente de ordem intelectual e artística. A dança segue suas tendências: do refinamento das formas, para consumo da nobreza, ao sentido do realismo insistente do povo. A prática da carola, nessa época, reflete o sofrimento da classe minoritária, pois já não retrata uma manifestação de alegria mas expressa “... o sentido da morte em sua realidade mais brutal.”13, tornando-se uma “dança macabra.”

Pesquisadores do assunto acreditam que essa denominação macabra, seja proveniente do vocábulo árabe "makhbar" que significa cemitério, local onde eram realizadas as danças de roda.

O hábito de se dançar em cemitério difundiu-se para demonstrar que a vida é uma roda, ou uma carola gerenciada pela morte. Dançava-se a “chorea” para reverenciar a morte, como fim primeiro de todo ser. Dançando-se à morte, preservar-se-ia a vida. Acrescenta-se, neste particular, o temor da população em percorrer necrotérios e principalmente cemitérios durante a noite. A noite representava, para as sociedades antigas, o perigo, a suspeita, o desconhecido. Acreditava-se que a noite pactuava com os assassinos, ladrões, fantasmas e demônios. Mais propriamente durante os períodos epidêmicos de peste, quando os cemitérios recebiam um número considerável de

\footnotetext{
${ }^{12}$ DELUMEAU, Jean. História do Medo no Ocidente. p.112.

${ }^{13}$ BOURCIER, Paul. A História da Dança no Ocidente. São Paulo, Martins Fontes,1987, p.56.
} 
sepultamentos, ouviam-se, com freqüência, ruídos partindo de dentro dos túmulos, devido aos gases provenientes da decomposição dos corpos. Para os supersticiosos da época, tais ruídos eram interpretados como avisos sobrenaturais de mais sofrimento e morte ou na evidência da força do demônio como causador dos ruídos.

“... na verdade, entre o cemitério e a epidemia (...) existem (...) o demônio e suas feiticeiras. Estas tiram dos mortos os elementos de que precisam para suas misturas e poções (...). Em tempo de peste, de fato, o demônio amplia o seu poder (...). De modo geral, tem delegação de poderes sobre os mortos: uma espécie de parentesco estabelece-se entre o demônio e os mortos. O cemitério faz parte do domínio dele, um vestíbulo do Inferno.»14

O cenário da ação é o necrotério e mais acentuadamente o cemitério. Como na carola, quando os habitantes firmavam uma espécie de pacto com a morte, o leitor também faz o mesmo com o capeta, neste ambiente considerado místico, uma relação amistosa, que não atinge a reverência, mas insinua uma permuta. A prática da carola ludibriava a morte, a decifração da charada preserva a vida. Nota-se que o conceito de capeta transmitido, especificamente, pela obra, refere-se àquela figura popular humanizada, suscetível de adulação, menos temível do que supunha a Igreja e passível de engano.

O desaparecimento súbito e o aparecimento inesperado das personagens, em cena, rememora as noites ofuscadas pela névoa, quando

\footnotetext{
${ }^{14}$ ARIÉS, Philippe. O homem diante da morte. Trad. Luiza Ribeiro. 2.ed. vol.II, Rio de Janeiro, Francisco Alves Editora, 1977, p.520-21.
} 
sombras humanas caricaturais, imensas e deformadas, volitavam pelo ar ou eram projetadas sobre um fundo incandescente de um recinto, aterrorizando os presentes.

Este bailado da personagem, nos cortes sucessivos das cenas, leva a outro pensamento. Apresentando características idênticas às sombras atemorizantes, a personagem pode, igualmente, ser adjetivada de macabra, uma vez que tenciona assustar o leitor. E macabra são as suas múltiplas representações - o vigia, o narrador e o leitor . Inseridas dentro da mesma classificação, estão as intenções do leitor quando, pelo ato de declinar as charadas para um receptor, este se reveste de sarcasmo e deboche.

A luminosidade, em contraste com a opacidade, favorece a criação de um ambiente, no qual a reprodução de sombras supõe o estranhamento, dada a pouca definição de formas.

A imagem desfocada das sombras, tal qual, evoca o jogo de espelhos, tão apreciado pela criança pequena, e traz, nas entrelinhas da memória, a brincadeira realizada num recinto escuro, cujo foco de luz centraliza-se numa vela. A penumbra possibilita a deformação da imagem dos participantes que, através da gesticulação e o movimento dos cabelos, insinua figuras de aspecto diabólico. Análoga a esse exercício lúdico, a manipulação dos dedos das mãos, na mesma proporção, favorece a criação de outras formas, como meio de recreação.

A composição ilustra, na penúltima página, o possível vigianarrador-leitor tentando descobrir algo através do orifício da fechadura, aspecto que o desqualifica como tolo, pois ele sabe que existe algo do outro lado da porta que pode lhe interessar. Trata-se de um jogo de sedução entre o leitor e as personagens, particularmente o capeta, que exerce fascínio porque conduz ao 
prazer que o desconhecido proporciona. O leitor, por sua vez, igualmente possui atributos que seduzem o capeta.

Eliade, sobre a questão da transposição de portas, passagens secretas, pontes perigosas recorrentes nos contos, argumenta que:

\begin{abstract}
"Convém precisar que todos estes rituais e simbolismos da 'passagem' exprimem uma concepção específica da existência humana: uma vez nascido, o homem ainda não está acabado; deve nascer uma segunda vez, espiritualmente; torna-se homem completo passando de um estado imperfeito, embrionário, a um estado perfeito, de adulto. Numa palavra, pode dizer-se que a existência humana chega à plenitude por uma série de ritos de passagem, em suma, por iniciações sucessivas." ${ }^{15}$
\end{abstract}

A pauta sobre a vida e a morte, a definição entre o bem e o mal, elementos imbricados na sua concepção, mas ainda pouco clarificados devido à imaturidade da mente humana, podem estar representados na narrativa, pelo homem e pelo demônio. O caminho amplo da vida, margeado pelo limiar estreito da morte, é uma questão que pode ser equiparada a uma charada, cuja decifração pertence a cada um.

Na seqüência final, o verbal assegura: “Quer saber de uma coisa? Estou de verdade no seu sofá ... no seu colo ... na sua mão ... Virgem! Que horror!! Estou nas suas mãos !!!! É mesmo o fim.”16

O depoimento frágil e despojado do narrador concede autonomia ao leitor. O estar no sofá, ou no colo do leitor não retrata a posição real daquele que

\footnotetext{
${ }^{15}$ ELIADE, Mircea. O Sagrado e o Profano. Trad. Rogério Fernandes. Lisboa, Livros do Brasil, 1956, p.188.

${ }^{16}$ LAGO, Angela. Charadas Macabras. p.31.
} 
tem nas mãos o livro. Trata-se do leitor ficcional, aquele introjetado dentro da estória, tão ficcional quanto o próprio narrador. A bipolaridade existente entre a fragilidade e a autonomia, observada no fragmento anteriormente referido, consolida algo que excede ao poder do texto verbal-visual - a proximidade entre o artista e o espectador, a intimidade entre a Arte e aquele que não pode alcançá-la em sua completude.

\subsection{Tradição oral em presença}

$\mathrm{P}$

ara o artista, que procura novas formas de expressão, as apropriações de elementos estruturais de cunho científico-tecnológico representam oportunidades amplas de experiência e um meio eficaz na elaboração de idéias e futuras criações. Para Plaza" "a dimensão estética da ciência reside no modo" como é representado o objeto e não no "que" representa.

Enquanto a ciência cria métodos e altera padrões através de estruturas, a sensibilidade artística intertextualiza-se com outros códigos de caráter tecnológico gerando interpretantes. No entanto:

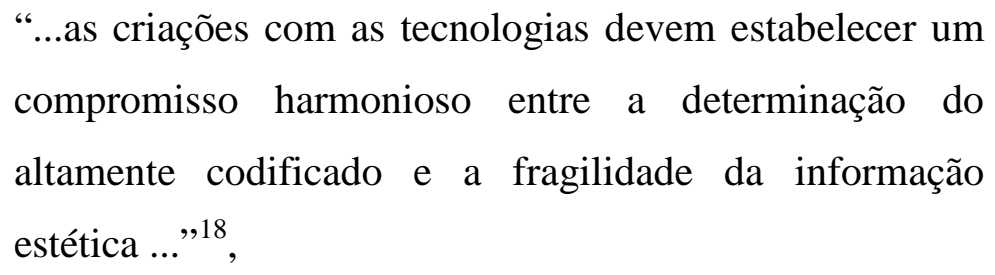

“...as criações com as tecnologias devem estabelecer um compromisso harmonioso entre a determinação do altamente codificado e a fragilidade da informação estética ...”,

\footnotetext{
${ }^{17}$ PLAZA, Júlio; TAVARES, Mônica. Processos Criativos Com os Meios Eletrônicos: Poéticas Digitais. São Paulo, Hucitec,1998, p.8.

${ }^{18}$ Idem, ibidem, p.11
} 
e nesse sentido, Charadas Macabras assegura o compromisso de deixar transparecer a interação existente nos meandros da arte, através da estética e o suporte tecnológico que vai corporificar a obra.

Arquitetada pelas malhas da "produção infográfica” (p.xiii) ${ }^{19}$, cujas particularidades não serão nesse segmento exploradas, a obra fundamenta-se em aspectos da cultura popular, primeiramente apoiando-se nas charadas denominadas tiburcianas ${ }^{20}$. A narrativa igualmente espelha-se em recolhas feitas por Angela Lago, acrescidas de sua criatividade, no que se refere à formulação de novas charadas.

Margeando este arsenal histórico, está a decifração de enigmas e charadas, no texto de Angela Lago, ora tomando parte em espetáculos visando ao entretenimento, ora ditando regras em rituais sinistros, como forma de salvação e preservação da vida. A postura sedutora do narrador convida, ou melhor, arrasta o leitor pelo caminho do desconhecido.

Este percurso proposto pelo narrador pode ser caracterizado como um desafio, um mergulho em águas profundas, como trilhas que vão desembocar nas narrativas do imaginário medieval.

Este imaginário configura-se, de acordo com a proposta de estudo de Todorov na obra Introdução à Literatura Fantástica, como gênero maravilhoso, por tratar-se de uma narrativa que aponta a existência de fenômenos sobrenaturais incontestáveis e que não podem ser explicados pelas leis naturais tais quais são conhecidas. Não se constata, por parte das personagens, hesitação perante a figura do diabo, aspecto que transportaria a

\footnotetext{
${ }^{19}$ Produção Infográfica refere-se a trabalhos artísticos, cujos resultados são obtidos pela intervenção do computador, conforme PLAZA, Júlio; TAVARES, Mônica em Processos Criativos com os Meios Eletrônicos: Poéticas Digitais.

${ }^{20}$ As charadas denominadas tiburcianas, cujo mérito pela invenção, caberia ao oficial brasileiro Antônio Tibúrcio de Souza, teriam sido declinadas por ocasião da Guerra do Paraguai, como forma de comunicação entre os oficiais, conforme LAGO, Angela. Charadas Macabras. p.3.
} 
obra para o universo do fantástico. Segundo Todorov, a noção de capeta faz-se a partir,

\begin{abstract}
“...de uma ilusão dos sentidos, de um produto da imaginação e nesse caso as leis do mundo continuam a ser o que são; ou então o acontecimento realmente ocorreu, é parte integrante da realidade, mas nesse caso esta realidade é regida por leis desconhecidas para nós. Ou o diabo é uma ilusão, um ser imaginário; ou então existe realmente, exatamente como os outros seres vivos: com a ressalva de que raramente o encontramos.”21
\end{abstract}

Verifica-se que, com a aparição do capeta, após a resolução da primeira charada, cria-se uma atmosfera de medo, envolvendo o vigia e o leitor, que dura um lapso de tempo. O texto verbal registra: “- É isso - geme o vigia (...) - ele grita e corre apavorado pelo corredor afora; (...) Agora você está sozinho, caríssimo leitor, (...) Sozinho? (...) Sei não. Só sei que você sua frio.”22 Mas o vigia sai de cena e o leitor predispõe-se às orientações do capeta.

\begin{abstract}
"Você está tonto e não consegue ouvir direito o que o demônio lhe fala. Ele aponta para esta porta, ou melhor, página, e você sabe que tem que entrar por ela. Na verdade, você pode ficar no corredor, ou então voltar pela porta anterior."23
\end{abstract}

A citação elucida a postura do leitor perante o diabo. O impacto

\footnotetext{
${ }^{21}$ TODOROV, Tzvetan. Introdução à Literatura Fantástica. Trad. Maria Clara C. Castello. São Paulo, Perspectiva, 1975, p.30-31.

${ }_{22}^{22}$ LAGO, Angela. Charadas Macabras. p.5.

${ }^{23}$ Idem, ibidem, p.9.
} 
inicial causado por sua presença cede lugar ao comportamento lógico e ponderado de quem precisa optar entre o incerto e o desconhecido dentro de uma situação limite.

Não ocorre, portanto, hesitação quando da corporificação do demônio, mas uma reação de surpresa das personagens, mesclada ao medo, até certo ponto natural, levando-se em conta o local da transformação: o necrotério, um ambiente naturalmente sinistro e por vezes assustador, local onde, servindonos de um adágio da cultura popular, os mortos fariam um breve descanso antes de prosseguirem rumo à sua última morada.

O resgate de elementos relacionados ao imaginário medieval corporifica-se na obra. A introdução paulatina no enredo, de assombrações, esqueletos e fantasmas, feita pelo narrador, dá-se através de um clima de descontração e riso, descontração esta ligada às expressões da oralidade, não mais de forma impactante, considerando as vias de introdução de tais personagens: “- Minha admiradora está gaga de tanta bronquite, ô alma penada! Uma, uma e duas - uma voz não menos horrível comenta. Admiradora com uma sílaba, fã. Fã, tá, asma. Sacou?”24

Quando o discurso assinala: "Mas você é um leitor desnorteado (...) Vá em frente (...) Não?! (...) Está com raiva de mim?”25 ou mesmo “Eu, o picapau, um passarinho! Até você está rindo, meu amigo leitor. É que ainda não sabe o que o espera." 26 , evidencia-se o elo de ligação entre a narrativa e o misticismo supostamente incrustado no leitor. No texto essa tendência ao comportamento místico pode ser interpretado como o rememorar da prática das danças macabras, realizadas nas noites escuras da Idade Média, em que sombras

\footnotetext{
${ }^{24}$ LAGO, Angela. Charadas Macabras. p. 15.

${ }^{25}$ Idem, ibidem, p.13.

${ }^{26}$ LAGO, Ângela, op. cit., p.12.
} 
representando formas humanas, vindas do além, atraiam pessoas de todas as idades para o bailado da morte. Por meio das charadas o narrador igualmente vai aguçar, atrair o leitor a tomar parte no seu jogo, como elucidaremos a seguir. Esse elemento místico pode ser compreendido como a disposição natural de se crer naquilo que pertence ao domínio do desconhecido, do sobrenatural, herança trazida da Idade Média; um tempo, de onde subtraímos “... as nossas raízes, o nosso nascimento, a nossa infância mas que é também um sonho de vida primitiva e feliz de que ainda mal saímos.”27 Um mundo considerado perdido, “... mas do qual temos ainda uma memória nostálgica: o tempo dos nossos avós. Uma idade Média à qual ainda estamos ligados pelo fio, não cortado, da oralidade. ${ }^{28}$

\subsection{A importância do jogar}

Terifica-se, desde a sociedade primitiva, a questão da ludicidade expressando-se na forma de jogo. De modo geral o jogo vai em busca de, luta pela posse de alguma coisa ou apenas representa algo, visando à realização do competidor. $\mathrm{O}$ ato de jogar gera tensão e incerteza quanto ao resultado, por isso aguça, desperta no participante o sentimento de competitividade que lhe é nato, porque carrega consigo, no seu campo de ação, o conceito de perigo, temor, risco, sorte-azar, tornando-se atraente e fascinante.

Em Charadas Macabras o jogo é fomentado pela palavra, através da linguagem poética. As charadas, que são lançadas juntamente com as regras do jogo, pretensamente apontam para o leitor um caminho pré-estabelecido. O

\footnotetext{
${ }^{27}$ GOFF, Jacques Le. O Imaginário Medieval. Trad. Manuel Ruas. 3.ed. Portugal, Estampa, 1994, p.41.

${ }^{28}$ GOFF, Jacques Le, loc. cit.
} 
observador-jogador aceita o desafio, não o da finalização da leitura, mas o de ser conduzido porque sabe que possui um adversário - o narrador. A idéia de ganho ou perda está expressa no final da narrativa quando cumpre ao observador impor um destino à competição.

O efeito claro e escuro marca o cenário reservado à prática da atividade lúdica proposta. É dentro deste círculo que o leitor, pseudo-norteado pelo narrador, tem encontros inesperados com fantasmas, assombrações e esqueletos, personagens que, paulatinamente, vão sendo introduzidos na narrativa. "Pois é, digníssimo leitor, você está no coração do cemitério. Agora, sim, você vai ver quem são meus personagens."29

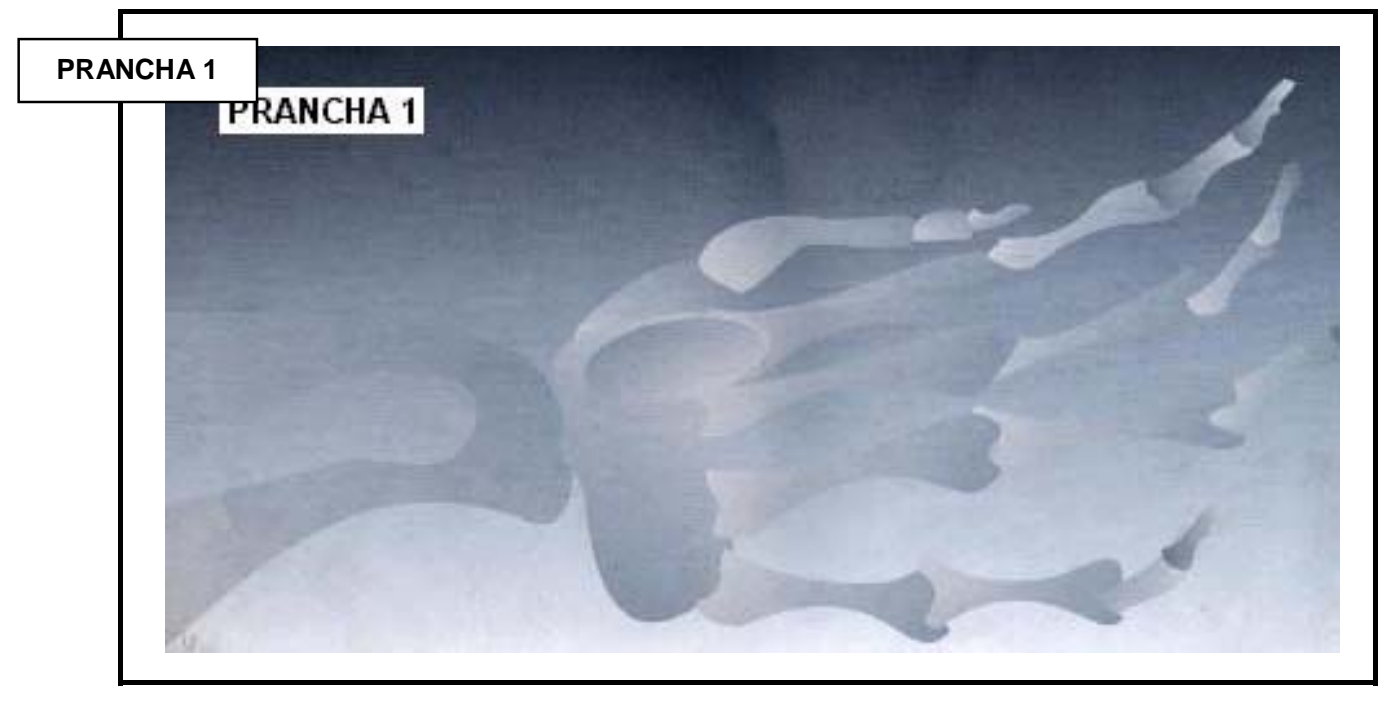

A opacidade dos desenhos, notadamente demarca o trajeto insinuado pelas sombras na névoa da noite. A imbricação entre sombra e névoa resulta numa mescla composta pelo estranhamento das formas e por mecanismos geradores de anseios, tendências e conflitos, embrenhados na mente humana, num jogo entremeado pelo real e imaginário.

\footnotetext{
${ }^{29}$ LAGO,Angela. Charadas Macabras. p.17.
} 
A ilustração, paralela ao verbal, não cumpre somente com a função do contar da estória, no que diz respeito ao campo de ação das personagens, mas entra no jogo ao desmembrar-se, perdendo contornos, tangenciando outras formas , abrindo espaço às infindáveis possibilidades de leitura.

\subsection{Na esfera da ação}

1 ação desenrola-se a partir da sala do necrotério. O vigia, que a princípio encontra-se junto ao leitor, segundo o texto verbal, subitamente foge, pois ele conhece a resposta da primeira charada - o Capeta, então, entra em cena. Ainda que a decifração das charadas não conte com a participação do espectador, o narrador o instiga a tomar parte neste lance que reclama paciência.

Pensamos neste segmento promover uma abordagem, ainda que desprovida de profundidade, embasada no estudo sobre os contos de magia, desenvolvido por Propp ${ }^{30}$, quando elenca as funções ou elementos invariantes que focalizam a ação das personagens no enredo.

Assim, teríamos enquanto situação inicial a meia e o pé do vigia que respondem pela metamorfose. Após esse momento, delineiam-se no enredo, as funções das personagens, com o afastamento do vigia: o capeta, no seu papel soberano de antagonista, não dialoga com o leitor, solicitando-lhe informações que possam ajudá-lo no seu intento, mas antes tenta ludibriá-lo através do ardil. O capeta utiliza-se da persuasão para induzir o leitor a fazer o seu jogo.

Decifrar as charadas implica transformação - a insegurança sentida inicialmente pelo vigia, causada pelo impacto, devido à aparição do capeta

\footnotetext{
${ }^{30}$ Vladímir Propp - teórico russo (1895 -1970), célebre pelo estudo pormenorizado, dentre outros, sobre os contos de magia procedentes do folclore russo.
} 
(comportamento sinalizado pela representação pictórica da personagem vigia) e o conseqüente enfrentamento do adversário, eleva-o à categoria de herói. Se o leitor não houvesse reagido, teria certamente morte súbita e o capeta passaria a triunfar diante do vencido. O leitor, agora herói, defronta-se com o antagonista, o inimigo. Dentro da proposta proppiana, este momento da ação narrativa é definido como o combate. A disputa opera-se em nível verbal. Ocorre o deslocamento espaço-temporal. Do necrotério as personagens atingem o cemitério, em constante competição. O capeta lança as charadas, introduzindo, na intriga, novas personagens, e o herói, pela esperteza, consegue chegar até à “derradeira porta” e reverter a situação. De vítima, aparentemente, dominada, o herói aceita o desafio e passa à posição de controlador da situação, pois o capeta que pode estar representado na figura do vigia ou do narrador, tem ciência do poder de discernimento do leitor. O leitor que não é tolo, exerce, desta vez, o poder e sabe que tudo não passa de uma brincadeira.

Uma vez mais, notifica-se o caráter dual da narrativa. O capeta, antagonista, transforma-se em doador e fornece as diretrizes adequadas ao sucesso do herói. O inimigo que, inicialmente, exercia o domínio absoluto sobre o leitor, termina em suas mãos. Consolida-se, assim, o confronto entre o herói e o falso herói, entre as forças do bem e do mal.

O meio ou o objeto mágico, aquele de que precisa o herói para vencer a prova, na narrativa, pode ser entendido como o uso correto da palavra que vai trazer o conhecimento e reverter uma situação.

Com a realização da tarefa, o herói não retorna de um reino distante depois de enfrentar o dragão, mas chega à porta do cemitério, aspecto que pode ser interpretado como o retorno ao real. A marca final da heroicidade também não recai sobre o casamento com a princesa ou na aclamação popular, mas no 
uso correto do poder mágico da palavra, responsável pelo ludíbrio do gênio do mal, aspecto que diverge em pormenores da classificatória elaborada por Propp.

\subsection{O tradicional em fusão com o atual}

1 relação intertextual com elementos das narrativas subtraídas da literatura clássica - O Pescador e o Gênio, ou O Gênio da Garrafa, conto compilado por Grimm ${ }^{31}$ convida o leitor a estabelecer uma analogia entre elementos dessas narrativas e aspectos presentes na obra em apreciação.

No conto popular, recolhido por Grimm, o pescador lança sua rede três vezes ao mar, sem sucesso. Na quarta investida a rede traz um jarro de cobre. De seu interior emerge uma figura gigantesca que ameaça de morte o pescador. Este porém, vence, pela astúcia, a fúria do gigante, mais freqüentemente denominado gênio.

Subestimando a capacidade do gênio em retornar ao interior do jarro ou garrafa, dadas as suas dimensões desproporcionais, em relação ao tamanho da vasilha, o hábil pescador induz o gênio a iniciar sua aventura de volta ao recipiente:

\footnotetext{
"Primeiro preciso saber se eras tu o prisioneiro da garrafa e se és mesmo o gênio que dizes. A garrafa é bem pequena, não sei se cabes de fato, dentro dela (...). O gênio, ofendido pela incredulidade (...), encolheu-se todo e foi minguando (...), até conseguir esgueirar pelo gargalho da garrafa.”32,
}

\footnotetext{
${ }^{31}$ Jakob Grimm e Wilhelm Grimm - filólogos e colecionadores de histórias populares (1785-1863)

${ }^{32}$ Contos de Grimm. Trad. Maria José U.A. Lima. São Paulo, Melhoramentos, 1968, p.235.
} 
fecha-o rapidamente e joga-o ao mar, ou, de acordo com outras versões, devolve-o “... novamente, entre as raízes do carvalho.”33

O elemento comum entre as duas narrativas incide no meio de salvação encontrado pelas personagens. Engenhosamente o pescador aprisiona o gênio pelo poder de persuasão, através da habilidade discursiva. Em outra vertente, o que se verifica é a força da palavra, na solução das proposições, como veículo libertador do poder do capeta. A descoberta das respostas certas norteia o leitor e o certifica sobre sua condição - onde e com quem está vivendo uma situação inusitada.

Em Charadas Macabras, não se constata, porém, o empreender de tentativas reiteradas do lançar da rede. $\mathrm{O}$ que realmente se busca, na primeira investida, é a resposta certa para a charada. A narrativa não cede lugar a tentames, não se "arrisca uma opinião." Enquanto o mar concede ao pescador quatro alternativas até que capture a garrafa, a narrativa oferece somente uma chance de decifração ao leitor, pois o narrador, em seguida à proposição, fornece a resposta - a aparição do capeta revela-se após a solução da primeira charada, sem direito a segunda chance. Na obra de Angela Lago, o leitor conta com um lance de acerto. Com o desenrolar do enredo, será disponibilizado a este leitor, inúmeras oportunidades de decifração de outras charadas, se realmente desejar livrar-se do capeta e sair do cemitério. Em $O$ Pescador e o Gênio, a personagem seguidamente aventura-se ao mar através da rede, porém conta somente com uma chance de salvação - ou aprisiona o inimigo na primeira tentativa ou é devorado por ele.

$\mathrm{O}$ aprisionamento do gênio, segundo o conto, durante quatro séculos: “- Sabes, gritou com voz tonitruante, qual será a tua recompensa por

${ }^{33}$ Contos de Grimm. p.236. 
me teres libertado? (...) vou quebrar-te o pescoço!”34, figura como a força maléfica reprimida; oculta, “engarrafada”35, não representa perigo, porém liberta, destrói, mata, não através da força física, como desejava o gênio, mas pela habilidade de convicção, trazida por meio da palavra, e pela manipulação dos desejos que seduzem. A palavra que escraviza o homem, também o liberta, porque aponta soluções e revela caminhos.

A figura malvada que se materializa diante do pescador ou do vigia, a princípio, representa uma ameaça. Instituído de conhecimento, o homem, na figura da personagem, não teme o mal porque conhece a verdade. Desembaraçando-se dos fios que o atam ao elemento pérfido, o homem torna-se livre. Assim, o assédio exercido pelo gênio-capeta, não se justifica, não há, portanto, razão para andar lado a lado com o homem, que, uma vez livre, segue o seu destino.

A transformação operada e o surgimento do capeta podem significar para o leitor (vigia) uma ocasião de ascensão. O aparecimento do demônio vai proporcionar oportunidade de reflexão quanto à presença do transcendental dentro do cotidiano, dentro do mundo dos possíveis, onde tudo é passível de transformação - a vida, em suas diferentes manifestações e até mesmo o desconhecido.

Particularmente, o conceito atribuído à figura do demônio tem sofrido severas transformações ao longo dos séculos. Para a Antiguidade, o demônio, amplamente denominado como Satanás, Satã, Lúcifer, Senhor das Trevas, significava o anjo perdido, “desgarrado do seio de Deus.” Na sociedade medieval, principalmente entre os séculos XI e XV, difunde-se a crença em um

\footnotetext{
${ }^{34}$ Contos de Grimm, p.236.

35 BETTELHEIN, Bruno. A Psicanálise dos Contos de Fadas. Trad. Arlene Caetano. 7.ed. São Paulo, Paz e Terra, 1988, p.39.
} 
ser mal e enganador, composto “... de uma substância sem corpo, que se apresenta sensivelmente aos homens contra a ordem da natureza e causa-lhes pavor."36 Caracterizado como uma figura de chifres, olhos e cabelos vermelhos, um enorme rabo e um sorriso sedutor, o diabo faz sua entrada triunfal no mundo ocidental. Temido pela sua autonomia exercida nos infernos, a figura do diabo esteve, durante um longo período, associada à chegada do Apocalipse e às conseqüências que o fim do mundo traria. A Idade Moderna, entretanto, nos seus primórdios, incumbiu-se da desmistificação do capeta. O conceito de demônio, no século XX, tornou-se tão descaracterizada dos atributos de outrora que as denominações “capeta”, “demônio”, “diabo”, “chifrudo”, “rabudo”, “demo” chegaram a um nível de vulgaridade tal que o seu uso tornou-se comum em praticamente todos as camadas sociais. São freqüentes expressões tais como: “É coisa do demo.” "Ele é um capeta em forma de gente." “Que diabos ele tem hoje?” não para exprimir a força que a figura do capeta representa dentro do pensamento social, mas como forma de exteriorização espontânea de idéias. O se percebe, então, é uma atualização, ao longo da História, das variadas interpretações atribuídas ao signo diabo.

\footnotetext{
${ }^{36}$ DELUMEAU, Jean. História do medo no Ocidente. p.87.
} 


\subsection{O embrenhar entre texto verbal e texto visual}

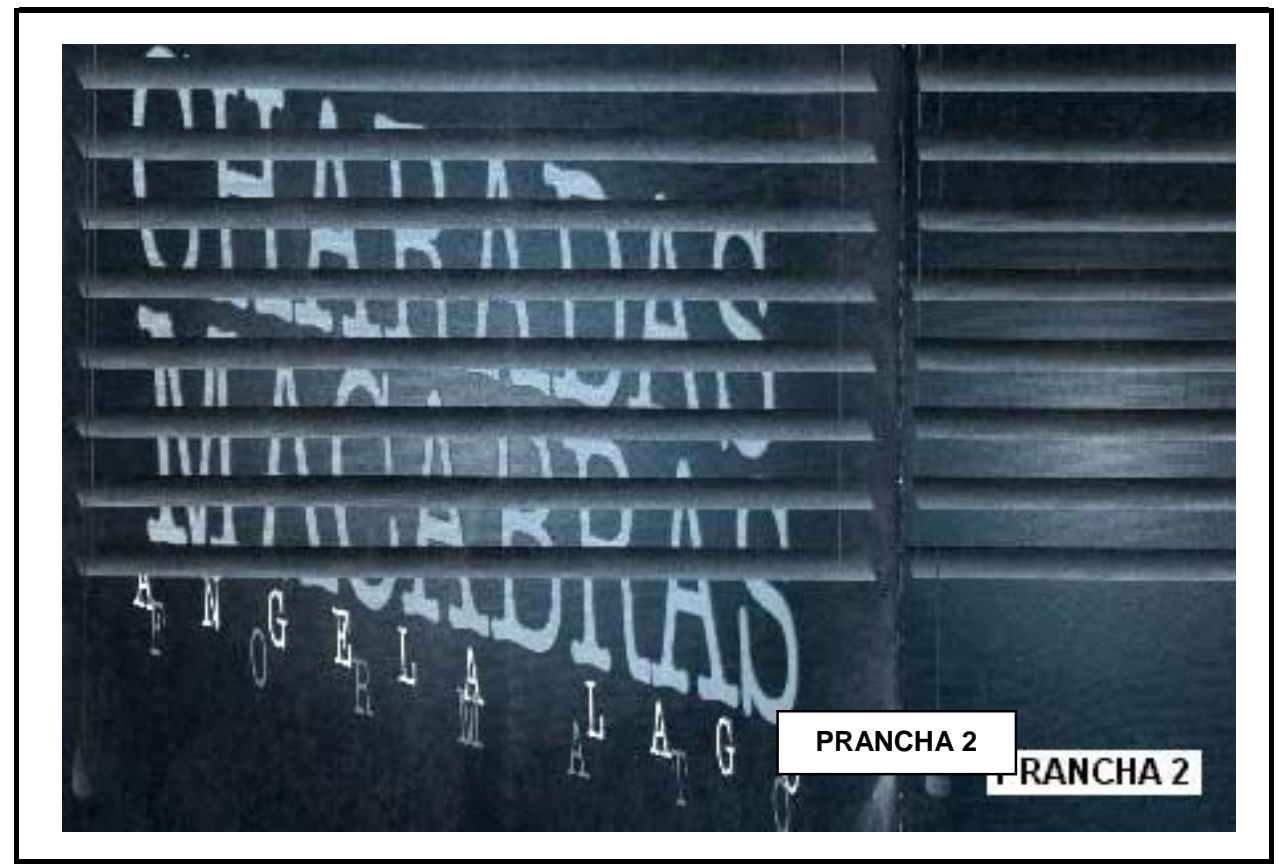

1 ilustração, de tonalidades variadas de azul, branco e cinza, principia a narrativa. Desprovida de moldura, a composição amplia-se em dimensão, a começar pela capa e contra capa, como mostra a prancha número 2. O traçado insinua uma sala contendo várias janelas, parcialmente veladas por cortinas. Em uma das janelas, tipos serifados sustentam, na diagonal, o título da obra - Charadas Macabras. Não se trata apenas de simples charadas, mas de charadas tétricas, macabras que lembram o sombrio e a morte.

O desalinho, tanto de vocábulos quanto de linhas, igualmente observado na página de rosto, é, segundo a ilustradora, um recurso proposital que visa salientar a tensão, a curiosidade, e conduzir o leitor "a entrar no clima da narrativa."37

\footnotetext{
${ }^{37}$ Informação obtida em entrevista a esta pesquisadora em 05 de Junho de 2000 em São Paulo.
} 


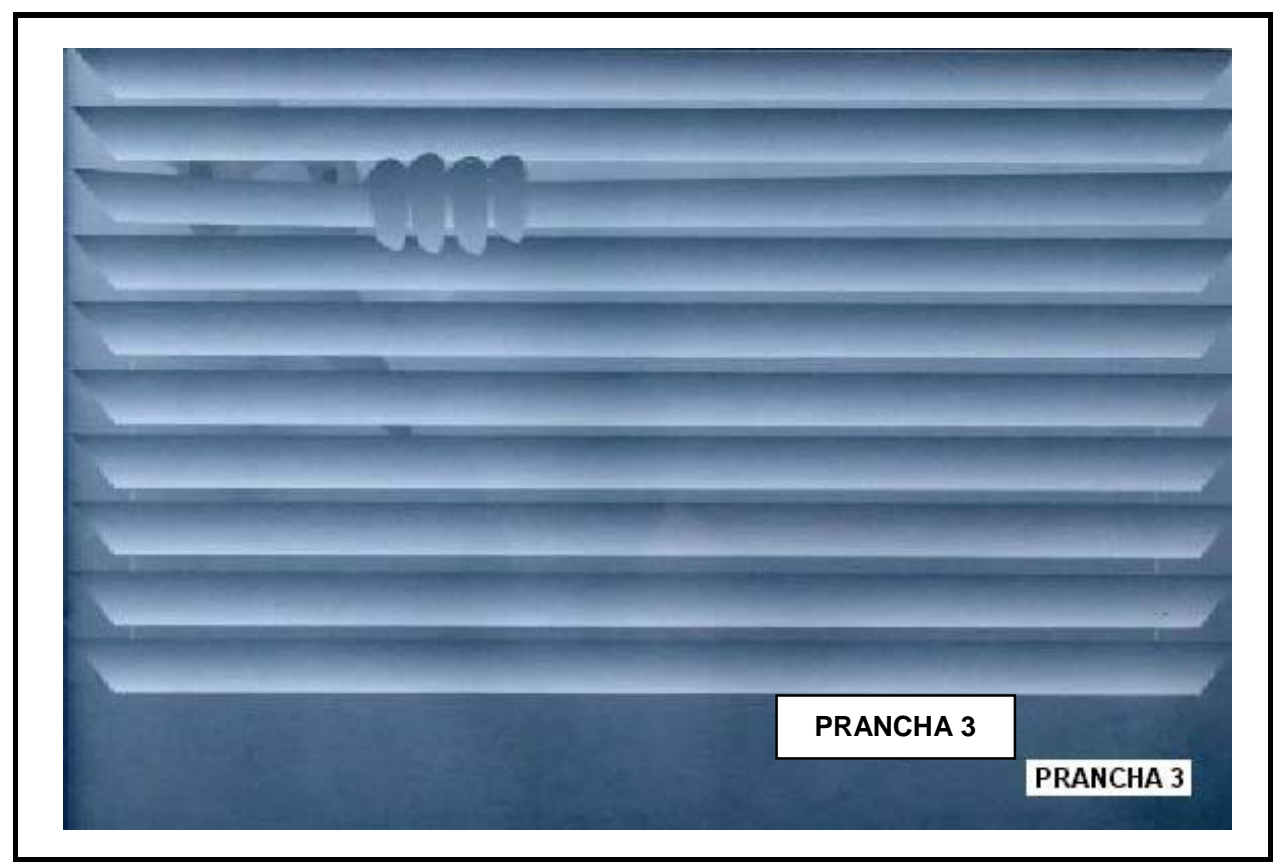

O primeiro quadro, de acordo com a prancha número 3, cientifica o leitor quanto ao grau de suspense da obra. Metonimicamente, a cena constrói-se a partir da caracterização de uma cortina, do tipo persiana. Uma de suas lâminas sustenta o traçado de uma mão que levemente a pressiona para baixo, deixando transparecer um par de olhos assustados que, misteriosamente observa o comportamento do espectador.

O leitor é o observador que capta os detalhes da cena, mais particularmente a expressão dos olhos da personagem. Porém, não se trata de uma observação à distância, alheia aos fatos em derredor. Registra-se uma simultaneidade comunicativa através do olhar, pois o olho que flagra é, ao mesmo tempo observado, de um outro ângulo. É o entrelaçamento entre o desenhar e o comunicar-identificar, que nasce nas entranhas da narrativa e frutifica, sincronicamente, na forma de decodificação da mensagem proposta.

Embora a ilustração, inicialmente, estabeleça comunicação com o leitor, não registra a sua inclusão no enredo, processo que se verifica através do 
texto verbal: "No momento em que o vigia apaga a luz da sala principal do necrotério, ele e você, caro leitor, escutam um sussurro..., „38

Uma observação criteriosa, porém, revela que os desenhos, digitalmente processados, começam a se organizar como formas apresentandose. O traçado, embora esmaecido, representa a relação de similaridade com as formas humanas. Os demais elementos que constituem a composição (estrutura cromática, textura, etc.), deixam de ter apenas similaridade na aparência quando atuam como coadjuvantes na geração de imagens que alicerçam a narrativa.

Dentro da construção temática, linhas e cores, associadas a elementos organizacionais, intercambiam-se para buscar outros signos, especificamente nesta oportunidade, através do delinear da aparência de uma tesoura aberta que, na seqüência ilustrativa, sugere o bico de um pica-pau, transformando-se na colher de sopa oferecida ao leitor, para em seguida insinuar as articulações de uma mão. ${ }^{39}$ É o processo contínuo de auto geração sígnica sendo, a todo instante, flagrado pelo olhar do observador que reconhece a mixagem, a sobreposição de formas que justificam não somente a presença da ilustração, mas possibilitam a ampliação do exercício perceptivo que capta, desde uma simples abstração mental, pura qualidade de sentimento, a um processo enredado de significados.

Ainda que os recursos enderecem à obra acentuado estranhamento, quanto à imagem, eles apresentam o real, mas um real visto pelo artista, aquele que possui a sua marca, o seu fazer poético. Quando o signo visual é utilizado pelo artista, ele, freqüentemente, supõe que haja um leitor capaz de imaginar,

\footnotetext{
${ }^{38}$ LAGO, Angela. Charadas Macabras. p.3.

${ }^{39}$ As pranchas referentes a esse segmento não puderam ser aqui reproduzidas devido ao nível de opacidade das mesmas.
} 
ainda que hipoteticamente, a sua idéia ou a sua intenção e interpretá-la de maneira coesa.

Nas formas ilustrativas, que se assemelham às personagens, predomina o aspecto caricatural. $\mathrm{O}$ esboço do vigia, esquematicamente posicionado no meio do livro - rosto afilado com nariz pontiagudo e orelhas de abano, óculos arredondados, supercílio em evidência, desencadeia no leitor, o riso, porque tornam perceptíveis, em tom exagerado, certas características negativas da personagem, que não se restringem ao desenho, mas referem-se à cena propriamente dita, entendidas como a falta de habilidade e conhecimento da personagem no trato com o capeta. O vigia, então, é apresentado como o tolo da estória, aquele que não entende nada, portanto, motivo de zombaria.

A cena aponta para o caráter referencial da personagem, quanto à forma, em semelhança com o objeto que se quer representar - um vigia apreensivo e contrariado com a presença do capeta no necrotério.

Demais aspectos, pertinentes ao processo de criação, são também veiculados através da linguagem verbal, quando, pela intercessão do narrador, uma nova personagem é introduzida no enredo. A singularidade na forma de abordagem, entretanto, denuncia a intimidade estabelecida entre narrador e leitor.

"Mas o que aquele cachorro está cavucando ecomendo?

Sei não. Até ovo podre, pra cachorro que não ladra, é doce (...). Por falar nisso, tem alma que acha cão febril uma delícia (...). Um rosto lambrecado com mel, um quitute (...). Você está com náusea? Não me diga que está imaginando coisas horríveis. Que cabeça a sua, leitor (...). Olha. Rebola a milionária comendo uma fruta (...). Mas 
cá pra nós, o que essa mulher está aprontando, comendo daquele jeito uma mexe-rica num cemitério? Virgem! Levantou a saia! Você viu? Eu enxerguei até a fruta da mulher de preto!

O recurso metalingüístico, igualmente, faz-se presente na narrativa. O narrador, na tentativa de enfatizar o canal de comunicação utilizado, emprega sentenças exclamativas, servindo-se da ironia, não para destratar o leitor, mas como forma de desmistificação do tema tratado. “... comportamento com duas, ação. Assombração. As dicas são perfeitas. É canja! Não tenho culpa se você é um tanto lerdo..." ${ }^{41} \mathrm{O}$ emprego deste recurso visa não somente atribuir à narrativa um caráter descontraído, mas afrontar o limite de raciocínio daquele que aceita o desafio.

Paralela à citação, a ilustração, de acordo com a prancha número 4, assinala a forma de uma mão sustentando uma colher, enfatizando assim, o meio utilizado na transmissão da mensagem.

\footnotetext{
${ }^{40}$ LAGO, Angela. Charadas Macabras. p.27.

${ }^{41}$ Idem, ibidem, p.14.
} 


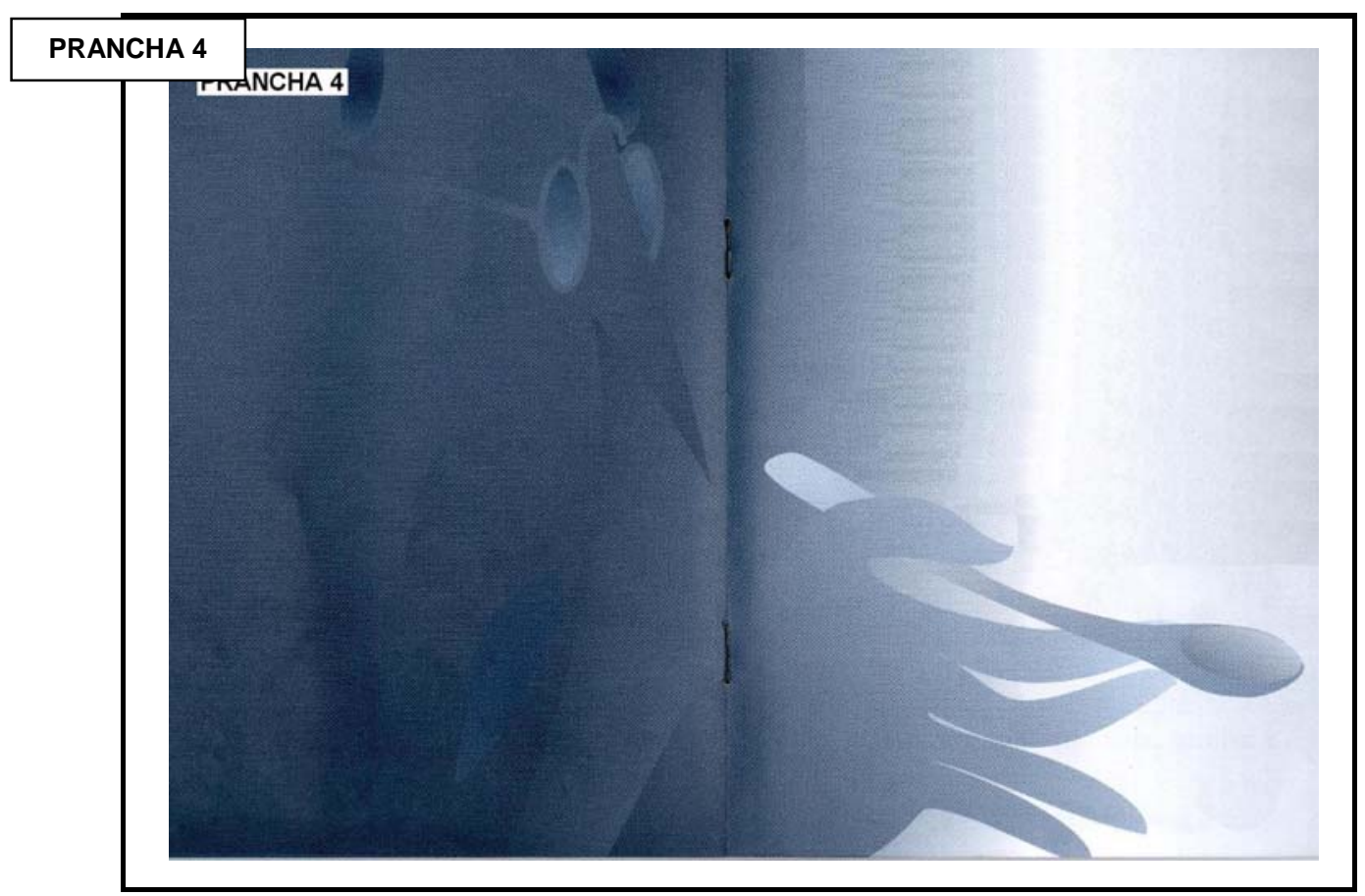

Segundo Jakobson: "Sempre que o remetente e/ou o destinatário têm necessidade de verificar se estão usando o mesmo código, o discurso focaliza o código..."42

O fragmento que sintetiza o assassinato da cantora Vilma é exemplar no tocante ao intercâmbio entre linguagens. O texto assegura:

“A Vil-má costuma ser fatal. Temperamental mais. Cantora. Foi morta pelo marido, um espanhol que toca violão. E foi por causa de uma nota que o cachorro lhe enfiou na goela a enorme faca." ${ }^{43}$

Correlativo imagético, pleno na transmissão da mensagem, e que antecede a decifração da charada, faz-se pela simulação de uma fenda, composta

\footnotetext{
${ }^{42}$ JAKOBSON, Roman. Lingüística e Comunicação. Trad. Izidoro Blikstein; José P. Paes. 8.ed. São Paulo, Cultrix, 1999, p.127.

${ }^{43}$ LAGO, Angela. Charadas Macabras. p.23.
} 
por linhas curvas paralelas, que se distanciam em certo segmento, as quais convergem para um único ponto de fuga, tornando-se referenciais, somente quando tomam a forma de punhal, assemelhando-se assim, ao objeto representado.

Presente na mesma composição, conforme prancha 5A, uma mão esquelética penetra o punhal na garganta da cantora, insinuando um ferimento profundo que transpassa o outro lado do pescoço da personagem. A seqüência ilustrativa é captada através do recurso da transparência de elementos, de um quadro a outro, como bem exemplifica a prancha número $5 \mathrm{~B}$, que indicia a ruptura da página. O esboço que sugere a incisão no pescoço da personagem, à parte a figura esquemática representacional, ajuda a decifrar a charada contida no texto verbal.
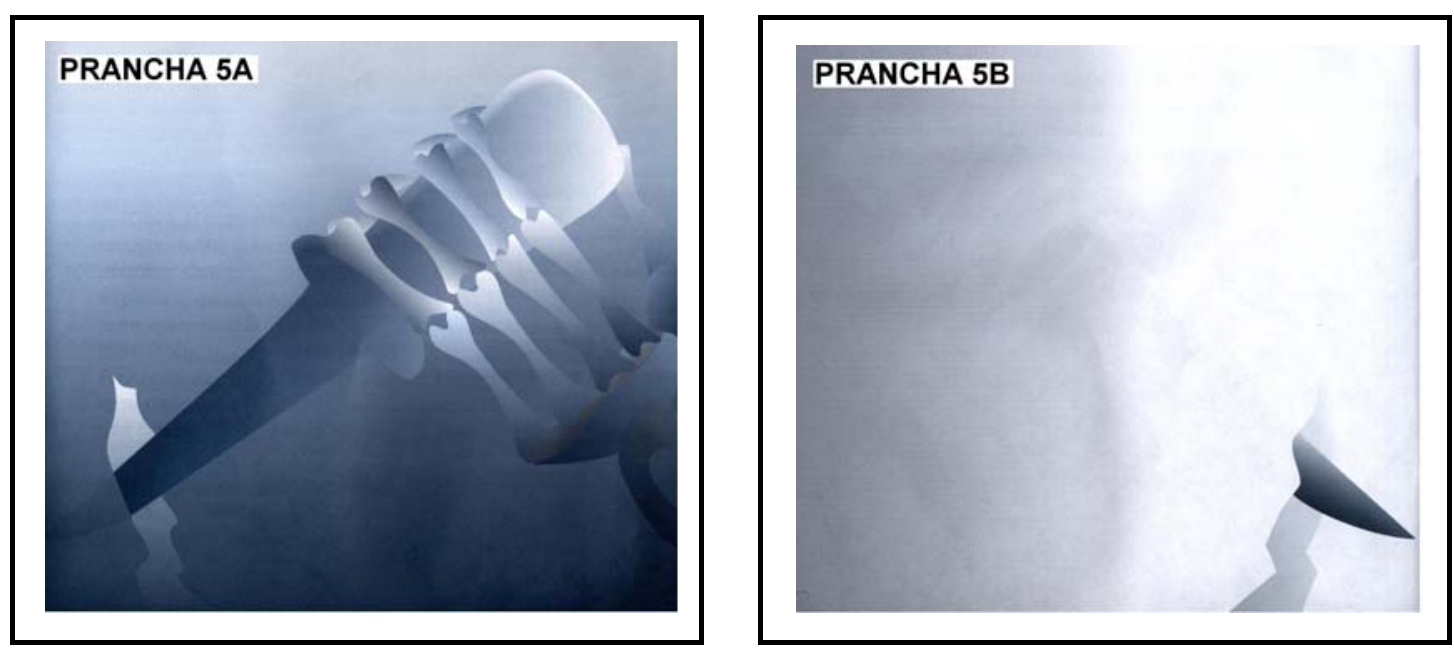
De acordo com a prancha número 6, os traços que marcam a gestualidade da personagem capeta, através da curvatura pronunciada do supercílio e a língua descomunal para fora da boca, expressam sarcasmo e deboche.

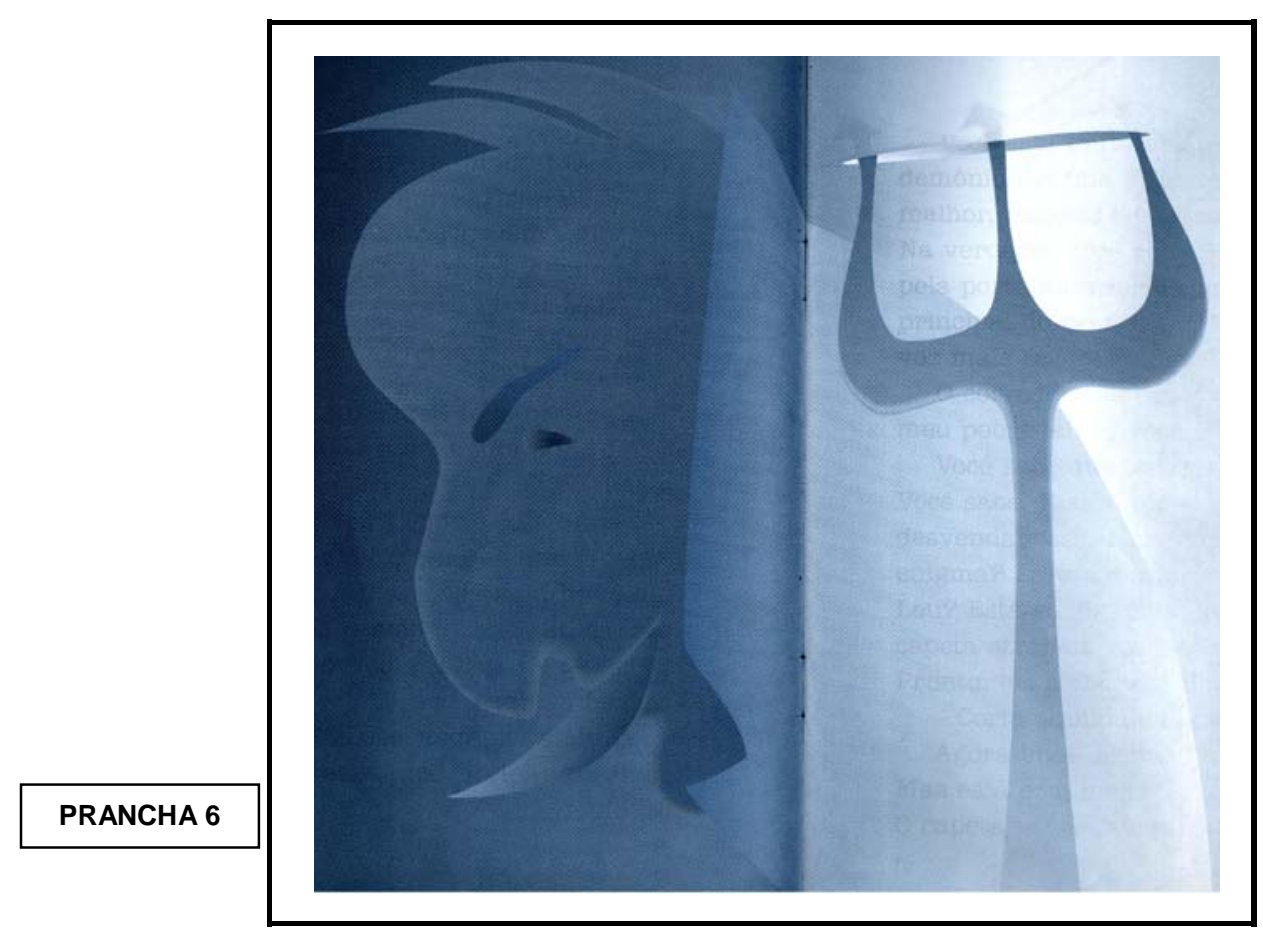

De acordo com Macedo:

“... entre os moralistas cristãos era comum a idéia de que os gestos desvelam os segredos da alma, revelando os impulsos íntimos e as intenções profundas (...). Todos os traços demoníacos eram exagerados intencionalmente. A arte clerical valorizava as proporções e a uniformidade. Tudo o que rompesse com a fixidez formal e majestática do sublime indicava o desregramento e a imperfeição (...). A fisionomia dos demônios, pelo riso excessivo, apontava o caráter devorador associado às forças satânicas.”44

\footnotetext{
${ }^{44}$ MACEDO, José Rivair. Riso, Cultura e Sociedade na Idade Média. São Paulo, Unesp, 2000, p.83-4.
} 
O riso de zombaria, ${ }^{45}$ que o traçado insinua, refere-se ao aparente domínio exercido pelo capeta. Reconhece-se, no riso da personagem, a indiferença pela falta de habilidade do leitor ficcional no trato do sobrenatural, daquilo que para ele ainda permanece velado.

Paralelamente, o leitor também vai identificar, através do recurso da caricatura, um detalhe que desencadeia o riso maldoso. O tamanho desproporcional da língua do capeta, insere-se como elemento pertencente ao domínio do cômico porque é indicial de uma deformidade tornada perceptível. De modo geral, os demônios possuem uma forma física grotesca. Citando mais uma vez Macedo, o autor caracteriza os corpos demoníacos de desproporcionais, “... aparentando formas híbridas em que se mesclam traços de anfíbios, répteis, símios e dragões.”46 Considerado como “... o ser mascarado por excelência (...).”47, o demônio possui a capacidade de mudar a sua aparência e assumir formas diversas, de acordo com a sua conveniência. Assim, o capeta implacável tem conhecimento sobre a insegurança do leitor, por isso faz caretas e mostra a língua. Mas o leitor sabe que por trás da máscara o capeta pode ser desnudado e tornar-se “... vítima de seu próprio ardil (...).”48 É então, pela via do riso que o homem (o leitor) vence o medo. De acordo com o pensamento medieval:

\section{“ Ao representar o horror com traços banais, a própria banalização era capaz de tornar o mal tolerável. Talvez encontremos nesse argumento a chave para compreender o porquê da figuração do diabo ter provocado duas}

\footnotetext{
${ }^{45}$ De acordo com PROPP, Vladímir. Comicidade e Riso. Trad. Aurora F.Bernardini ; Homero F. Andrade. São Paulo, Ática, 1976, p.28.

${ }^{46}$ MACEDO, José Rivair. Riso, Cultura e Sociedade na Idade Média. p.84.

${ }^{47}$ Idem, ibidem, p.86.

${ }^{48}$ MACEDO, José Rivair, op. cit., p.87.
} 
sensações aparentemente contraditórias, mas perfeitamente conexas: o terror e o cômico.”49

Verifica-se então, uma simultaneidade, no tocante à ironia. A postura de zombaria, ora estabelecida, ofusca-se perante a perda de poder do capeta sobre o leitor e a um ato maquinal que ganha espaço e passa a designar um motivo de sarcasmo. Mostrar a língua é uma prática popular que expressa deboche. Na obra, é entendida como um ato mecânico e repetitivo que denota rigidez, por isso, provoca o riso. Assim, “ as atitudes, gestos e movimentos do corpo humano são risíveis na medida exacta em que esse corpo nos faz pensar numa simples mecânica."50 Atentando-se para a semelhança de traços entre a personagem capeta e o homem, este se insere no mesmo pensamento sobre aquilo que pode ser considerado risível.

Outro recorte que sintetiza a diversificação das imagens, como processo de criação, refere-se à representação figurativa do garfo de três pontas, instrumento perfurador de uso comum dos demônios, a cujo detalhe o texto verbal não faz menção. O desenho, de contornos irregulares, conduz o leitor a formar uma idéia generalizada da representação daquele objeto. No nível referencial, o observador será capaz de identificar os aspectos da composição como características pertinentes ao objeto que se quer representar. O conceito que se tem sobre o garfo pontiagudo deve-se ao caráter de significação convencional. Constitui-se regra geral, atribuir ao garfo de três pontas uma conotação negativa. Desde a mais remota representação pictórica do demônio, o instrumento perfurador figura como elemento de tortura, amplamente utilizado,

\footnotetext{
${ }^{49}$ MACEDO, José Rivair. O Riso, Cultura e Sociedade na Idade Média. p. 87.

${ }^{50}$ BERGSON, Henri. O Riso. Ensaio sobre a Significação do Cómico. Trad. Miguel S. Pereira. Lisboa, Relógio D’Água, 1991, p.29.
} 
segundo a tradição, para empurrar os condenados para dentro dos domínios de um suposto inferno.

Os graus de interpretabilidade, em nível verbal, tomam lugar na obra com a exposição das charadas que cumprem, não somente com a função fática do texto, mas permitem o desvelar dos significados mais amplos da narrativa. A estrutura morfológica, inserida na língua como sistema de lei, compõe os enigmas e vitaliza as personagens, viabilizando sua atuação na narrativa. “... Aqui, Cá. Dentro do sapato, pé ... está, tá - é você falando. - Cá pé tá!” 51

Quando o observador, pela repetição sucessiva dos sons abstrai, desse processo, o vocábulo “capeta” e o conceitua, tem conhecimento da sua influência e atuação no enredo. A linguagem articulada, em diálogo com o leitor, assegura, enfaticamente, a presença da personagem. “- Cá pé tá! - você está gritando!!! Acaba de ver um vulto chifrudo e lingudo tomar forma e, (...) escapulir do sapato do vigia.”

O confluir, então, do texto e da ilustração vai facultar a geração de interpretantes. Segundo Santaella, um interpretante é:

“... uma propriedade objetiva que o signo possui em si mesmo, haja um ato interpretativo particular que a atualize ou não. O interpretante é uma criatura do signo que não depende estritamente do modo como uma mente subjetiva, singular possa vir a compreendê-lo. $\mathrm{O}$ interpretante não é ainda o produto de uma pluralidade de atos interpretativos, ou melhor, não é uma generalização de ocorrências empíricas de interpretação, mas é um

\footnotetext{
${ }^{51}$ LAGO, Angela. Charadas Macabras. p.7.
} 
conteúdo objetivo do próprio signo.”52

A obra "in totum” desvela níveis diversos de interpretantes que não serão, nesse segmento abordados. Através do vocábulo "Capeta”, que funciona como um canal de informação, o intérprete, neste particular, o leitor, sofre o efeito produzido pelo signo, ou seja, apreende o seu conteúdo significativo. É comum se relacionar, à figura do capeta, a força maligna, o poder, as penas eternas, etc., porque tais atributos já se tornaram um hábito, fazem parte do inconsciente coletivo. A presença da palavra capeta potencializa uma interminável cadeia de significações. No tocante à ilustração, o que se verifica, não é somente um diálogo profícuo com o verbal, por meio do recurso metalingüístico, mas um rompimento dos padrões diagramáticos convencionais. No alto da página, observa-se o garfo de três pontas abrindo uma lacuna na página. Versatilidade da artista em comunicação direta com o espectador ou o instinto impulsivo, a auto-afirmação do representante do mal revelando-se e instigando o poder de interpretação do leitor.

O jogo de semelhanças, ratificado no texto, não se opera no âmbito da qualidade, mas da representação, da sustentação de idéias. No domínio da terceiridade, vocábulos de significados diversos, fisicamente unidos, adquirem outra conotação e geram outros signos. Ainda que as charadas representem o meio pelo qual o referente vai estar em relação com o objeto, o enfoque incide não no modo como será dito ou demonstrado essa relação. O que está em evidência não são os viéses das charadas, como são declinadas ou demonstradas, mas o resultado dessa imbricação sígnica, entendida na obra, como as respostas, obtidas na forma de outro vocábulo, de caráter relevante.

\footnotetext{
${ }^{52}$ SANTAELLA, Lucia. Teoria Geral dos Signos. Semiose e Autogeração. São Paulo, Ática, 1995, p.85.
} 
O caráter polissêmico das palavras edifica a matéria plástica. Sentenças aparentemente desconexas “- ... esse deputado cozinha no forno aquele outro que badalava na igrejinha ...”, 53 geram, por meio do processo sinonímico e dedutivo, outros signos. Os vocábulos “cozinhar” e "badalar” possuem, pela força significativa das palavras, o seu correlativo; desse modo, “cozinhar” é “assar” e "badalava” é "sino”. Assim, unidos pela justaposição, os vocábulos, produzem um outro signo de significado similar: "assassino”.

O código visual, contudo, não se subordina à estrutura verbal; o que existe é uma interligação entre as duas formas de linguagem possibilitando a auto-referencialização.

Com sutileza o narrador instiga a curiosidade do observador, induzindo-o a resolver as sucessivas proposições.
“Ai! Que calafrio! Leitor, você devia parar e tomar um café ou um refrigerante, é muita tensão. Agora você quer matar a pau. Então como é que é? "54

O conteúdo diagramático, nesse segmento, faz eclodir à mente a idéia de uma mão segurando uma colher, para referenciar o conteúdo verbal. Dentro desse processo verbal e visual a narrativa vai-se construindo e deixando marcas, aspecto de cunho interpretativo, que o leitor, paulatinamente, descortina e justifica.

A falta de horizontalidade do signo verbal, através do esboço de um dedo de unha pontiaguda, desalinhando o vocábulo “empurra”, endereça movimentação à composição, estabelece semelhança na qualidade da aparência do objeto representado; mas, sobretudo, insinua, próxima ao desenho, a saída do

\footnotetext{
${ }^{53}$ LAGO, Angela. Charadas Macabras. p.25.

${ }^{54}$ Idem, ibidem, p.15.
} 
leitor pela porta, discretamente delineada ao fundo da página. O signo visual transcede à função de suporte de enquadramento do texto; porta e página fundem-se, então, numa relação diagramática. “Agora você hesita. Tenta compreender. Mas está com medo. Sim, medo! Muito medo! O capeta te empurra ..."55

Texto verbal e texto visual revelam, revelando-se. A representação de "Caio", a personagem esqueleto, personificado, interage com a estrutura verbal. Pela geração dos signos o verbo perde a referencialidade com o ato de cair. Utilizando-se do recurso do trocadilho, o narrador transforma os nomes próprios “Caio” e "Rui”, nos verbos “cair” e "ruir”. "Este se apresentando, é o Caio. Está caindo aos pedaços.” ${ }^{56}$ Empurrado por Caio, Rui, que “... já estava mesmo para ruir" ${ }^{\text {57 }}$, também desmorona. Na seqüência, a obra configura uma mão, indiciando imagem em raio $X$, que transcede, da imagem (figura) à palavra. A composição por si se auto-sustenta. No seu interior já está introjetada a idéia proposta pela ilustradora - a interconexão entre a ilustração e o texto.

A figura da mão esquálida pode alcançar patamares de representação tais como a morte, em primeira instância, como reação que “... pode corresponder à manipulação e exploração das imagens do nosso mundo interior." ${ }^{58}$; desejo de se fazer uma releitura da anatonia do corpo humano, captar as entranhas, olhar o ser em profundidade ou a possível relação do significado da palavra “Caio” com a disposição do desenho na página - uma mão caída, inanimada, em pedaços e, assim, infinitamente. Faz-se oportuna,

\footnotetext{
${ }^{55}$ LAGO, Angela. Charadas Macabras. p.9.

${ }^{56}$ Idem, ibidem, p.19.

${ }^{57}$ LAGO, Angela, op. cit., p.20.

58 SANTAELLA, Lúcia. Teoria Geral dos Signos. Semiose e Autogeração. p.105.
} 
então, nesse momento, a citação de Oliveira: “A imagem é uma palavra articulada., 59

O texto, narrado em primeira pessoa, evidencia os traços autográficos do locutor através do uso da linguagem figurada. "Por que estou lhe contando isso tudo? Ora, ora. É isso que um escritor faz. Com um pano cheio de buracos, sozinho, costura o mundo das idéias."60

Contida no fragmento acima, a metáfora refere-se à criação literária. Dentro desse processo de criação, o narrador situa os dois universos paralelos: o abstrato (idéias) e o concreto (palavra escrita). A metáfora visual, que acompanha o texto, pode ser representada como instrumental da tessitura narrativa. As formas agulha e linha, dispostas na página, podem sugerir a caneta, o pincel ou mesmo o "lápis eletrônico”61 que costuram o pano, o próprio ato da escrita, como pode ser observada na prancha a seguir.

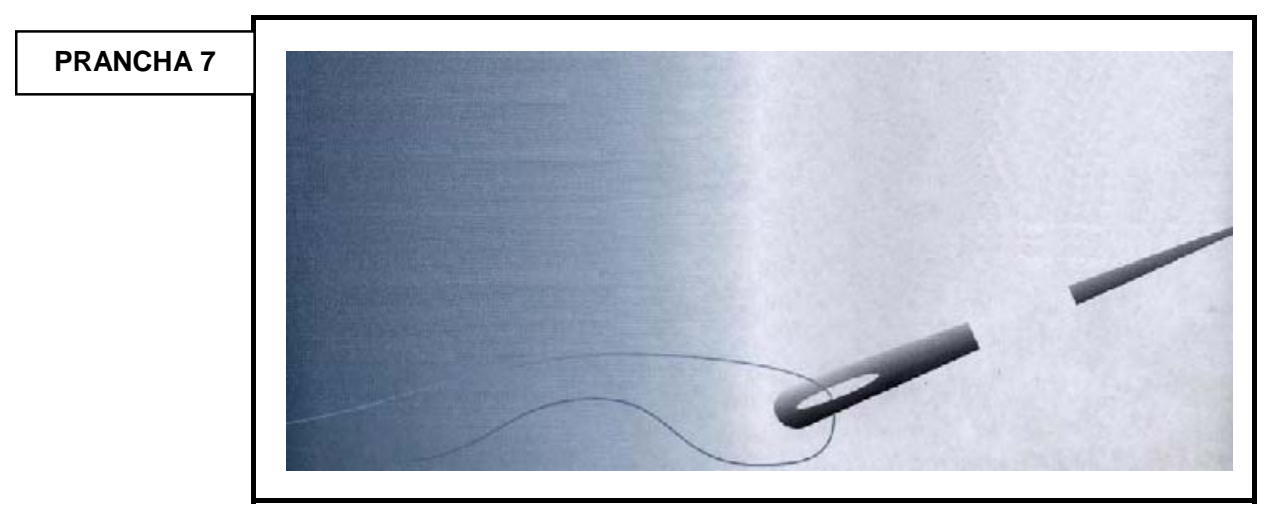

A lacuna, livre, sem costura, entendida como recurso utilizado pelo narrador, permite ao espectador o seu preenchimento, a sua participação como co-autor do alicerce narrativo. Naturalmente, por mais que o artista procure

\footnotetext{
${ }^{59}$ OLIVEIRA, Valdevino Soares. Poesia e Pintura. Um Diálogo em Três Dimensões. São Paulo, UNESP, 1998, p. 45.

${ }^{60}$ LAGO, Angela. Charadas Macabras. p.25.

${ }^{61}$ A expressão "Lápis Eletrônico" foi utilizada por Angela Lago no Seminário "Literatura Arte Educação. Intencionalidades da Ilustração” (1990), realizado na cidade de São Paulo.
} 
entrelaçar as idéias, visando à coerência textual, ele deixa fendas, difíceis de ser preenchidas, porque são inerentes à Arte. São espaços abertos onde se lêem as entretinhas, os caminhos, através dos quais discute-se, o caráter da obra, se poético-pictórica, somente pintura ou somente poesia, etc, dada à sua complexidade.

A autonomia dada ao leitor, durante o segmento narrativo, transpõe-se, no final, e este passa a figurar como aquele que deve concluir a estória, através da última proposição, dar-lhe continuidade, pelo uso reiterado da palavra ou atribuir-lhe plasticidade, por meio da modalidade pictórica. A autogeração sígnica, pertinente às configurações agulha e linha, consiste na deformação, aqui especificamente, de uma imagem visual em prol de outra, objetivando-se o seqüenciar de uma idéia. O verbal assegura: “A tumba está embaixo de um jaz mineiro, um jasmineiro!"62 O texto visual reflete-se, de uma página a outra. Assemelhando-se a portas, as páginas abrem-se, exibindo cenas que, gradativamente, transformam-se, como se "estivessem" submetidas ao efeito cinematográfico. Na sucessão contínua dos quadros, os galhos de jasmineiro sugerem a forma de raios, prenunciando tempestade. "Parece que vem tempestade. Vamos embora, que estou ficando nervosa.”63 Enquanto o traçado da agulha e linha e a configuração dos raios assemelham-se ao objeto representado, os galhos de jasmineiro divergem no grau de representação. A imagem que a artista disponibiliza na cena em que figura o jasmineiro não atende ao padrão de expectativas do observador. A imagem não transita no mesmo patamar que o texto verbal, de outro modo, a ilustração poderia até mostrar uma árvore, a flor jasmim ou até mesmo um túmulo.

\footnotetext{
${ }^{62}$ LAGO, Angela. Charadas Macabras. p.27.

${ }^{63}$ Idem, ibidem, p.29.
} 
De sentido denotativo os vocábulos “jaz-mineiro”, pela justaposição, no ponto de vista da criação das palavras, transformam-se em “jasmineiro”. O jogo de palavras endereça à narrativa um tom de descontração que chega a provocar o riso. O narrador admite o exercício da função poética, lançando os seus recursos, quando classifica de "pura poesia",64 a brincadeira que faz com os morfemas. Texto e ilustração entrelaçam-se na revelação estética.

Perseguindo as pegadas do texto, observa-se que as citações: “O chato é esse capeta atrás de você, te arrastando linha em frente (...). Céus! E agora? Onde é que viemos parar? Nas últimas páginas? Na derradeira porta?”, 65 compõem-se de metáforas que evocam, na mente do leitor, não imagens que correspondem à extensão do conceito das palavras empregadas, mas um significado diverso. Por linha, pode-se entender o percurso que o narrador instiga o leitor a fazer - do necrotério ao cemitério, ou, até a própria seqüência narrativa na sua completude estrutural. Páginas e porta podem figurar como saída, abandono, fim, etc. A multiplicidade interpretativa da obra relaciona-se com o poder de criação e imaginação da artista, sua desenvoltura no trato com a linguagem verbal e visual.

Vale ressaltar, ainda com relação à força geradora das palavras, o percurso traçado pelo narrador, em parceria com o leitor. A narrativa gravita em torno do sinistro e do cômico. Como precisar o grau de intencionalidade do narrador, ou seja, onde estabelecer, se possível, o limite entre a brincadeira e a seriedade, o real e o imaginário?

A ausência de detalhes na imagem, responde pelo quadro final e conclusivo da narrativa. Localizado acima, no canto esquerdo de uma das

\footnotetext{
${ }^{64}$ LAGO, Angela. Charadas Macabras. p.27.

${ }^{65}$ Idem, ibidem, p.30.
} 
páginas está, diagramaticamente referida, a forma de um orifício de fechadura, esboçada na cor branca.

Na página subseqüente o jogo de luz e sombra, na gradação cinzabranco, pode insinuar o traçado de uma porta semi-aberta. No mesmo recorte, a representação de alguém que pode ser o vigia, o leitor ou outra personagem (capeta, fantasma, assombração, etc) posiciona-se como espião, conforme podemos observar na prancha seguinte.

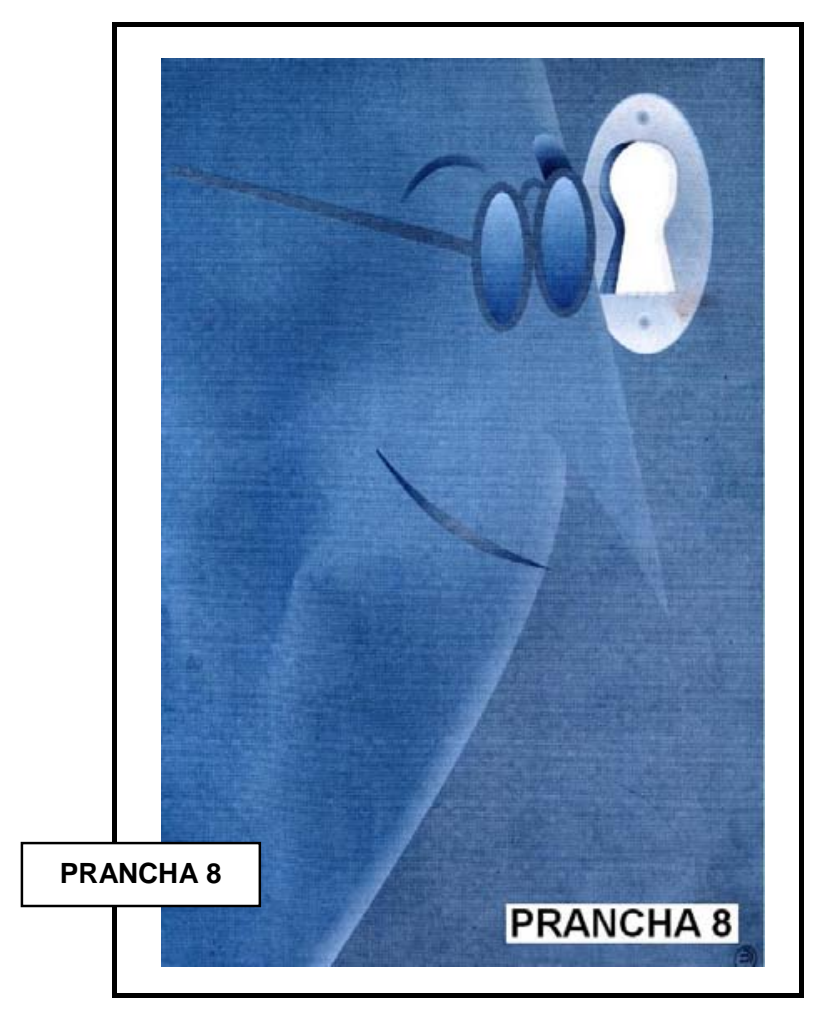

O sorriso sagaz, no canto dos lábios da personagem, indica curiosidade. A figura de traços humanos "espia" pelo "buraco" da fechadura, na tentativa de desvendar o lado oculto da estória.

A representação do ato de olhar às escondidas pode oscilar entre o comportamento infantil, referenciando à criança traquina, "encapetada", que a tudo procura alcançar, ainda que seja através da observação indiscreta, ou a um 
remate do próprio jogo proposto pela narrativa. A personagem que pode ser o vigia, age como o capeta, que a qualquer preço, mesmo servindo-se da invasão da privacidade alheia, busca satisfazer um capricho. A atitude não é questionável, pois faz parte do jogo.

Retrocedendo ao início da obra, mais especificamente, ao primeiro quadro, quando o delinear de uma forma humana observa à distância, através da janela, e, estabelecendo um traço de semelhança com a cena final da narrativa, deduz-se tratar-se da mesma personagem, em atitude similar, ou de uma possível transformação.

Após a aparição do capeta, o vigia sai de cena. Ao retornar, apresenta uma expressão facial tensa. Pelo conteúdo textual, poderia estar representando o leitor desorientado, perante o inusitado. "Mais uma vez, apressadíssimo leitor, você virou a página..”66 Mas, quando na página seguinte, o verbal informa: “As dicas são perfeitas. É canja!”67, é a voz do narrador que comparece. Assim, a figura representacional, de posse de uma colher, não se reporta mais ao vigia, nem tão pouco ao leitor, mas alude ao narrador que fornece pistas em prol da decodificação da mensagem.

A personagem, plasticamente falando, ausenta-se novamente. No entanto, o diálogo com o leitor, registrado pelo verbal, prossegue até a conclusão da narrativa.

\footnotetext{
${ }^{66}$ LAGO, Angela. Charadas Macabras. p.14.

${ }^{67}$ Idem, ibidem, p.15.
} 
Relação de Pranchas referentes ao capítulo 1.

Prancha 1

Prancha 2

Prancha 3

Prancha 4

Prancha 5A

Prancha 5B

Prancha 6

Prancha 7

Prancha 8 p.21

p.28

p.29

p.33

p.34

p.34

p.35

p.42

p.45 


\section{Capítulo 2 DA ORALIDADE AO RECONTAR DOS TEMPOS MODERNOS EM SUA ALTEZA A DIVINHA}

“Aquele que sabe contar belas histórias não deve guardálas para si quando encontra boas pessoas; ao contrário, deve transmiti-las, as melhores e as mais picantes, sobretudo se os ouvintes estiverem bem sentados e prestando atenção porque, no fim, todos ficarão contentes.”

Anônimo Séc. XIII

\subsection{Uma aventura no tempo}

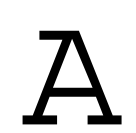

procedência de Sua Alteza A Divinha resulta de uma experiência vivenciada por Angela Lago, como contadora de estórias. De acordo com a autora, o conto, sobre uma princesa que propunha adivinhas, despertava interesse e curiosidade nas crianças. "Elas o achavam engraçado e interagiam comigo, acrescentando detalhes, contando suas adivinhas prediletas, macaqueando os personagens."

Sendo assim, era uma vez uma princesa que, de adivinhações em adivinhações... Adivinhe! Virou A Divinha. Este é o ponto de partida da obra. Através do intercâmbio entre texto e ilustração, a narrativa, apoiada na cultura oral, trabalha pelas vias do elemento lúdico, a criatividade das personagens e do

\footnotetext{
${ }^{1}$ Informação obtida no Seminário “Literatura Arte Educação. Intencionalidades da Ilustração”, proferido por Angela Lago (1990), realizado na cidade de São Paulo.
} 
próprio leitor. Perspicácia e imaginação, neste jogo, são pré-requisitos exigidos, instrumentos que podem ou não assegurar o sucesso ou a derrota do competidor.

O conto narra que uma princesa de nome A Divinha, em tempo de se casar, impõe aos candidatos, como forma de seleção, três adivinhações. Ao vencedor a recompensa é a sua mão, ao perdedor cabe a forca como punição. Observe-se que a busca feminina é marcada não pelas vias do encantamento, mas pelas adivinhas que são lançadas. É de direito dos pretendentes também declinar suas proposições. Como detentora do poder, a não decifração das adivinhações não implica punição para a princesa. Conclui-se a narrativa com a união equilibrada dos princípios masculino e feminino. A Divinha casa-se com Louva-a-deus e são eternamente felizes.

O período de aventuras vivenciado por Louva-a-deus, tem início com a partida do aldeão de seu lugar de origem, até a chegada ao castelo. A ação desenvolve-se “... num fundo geográfico amplo e variado (...)”2, muitas vezes, num país estrangeiro ou num reino distante, fora do círculo social da personagem. Trata-se do “... tempo mítico, ou melhor, o tempo imutável, eterno, que se repete sempre igual, sem evolução nem desgaste (...).”’3 No texto tal referência temporal resume-se a: “Era uma vez uma (...).”4,conforme prancha número 1.

\footnotetext{
${ }^{2}$ BAKHTIN, Mikhail. Questões de Literatura e de Estética. Trad. Aurora F. Bernadini. 4.ed. Unesp, 1998, p. 214.

${ }^{3}$ COELHO, Nelly Navaes. A Literatura Infantil. 4.ed. rev. São Paulo, Quíron, 1987, p.55.

${ }^{4}$ LAGO, Angela. Sua Alteza A Divinha. Belo Horizonte, RHJ, 1989, p.1.
} 


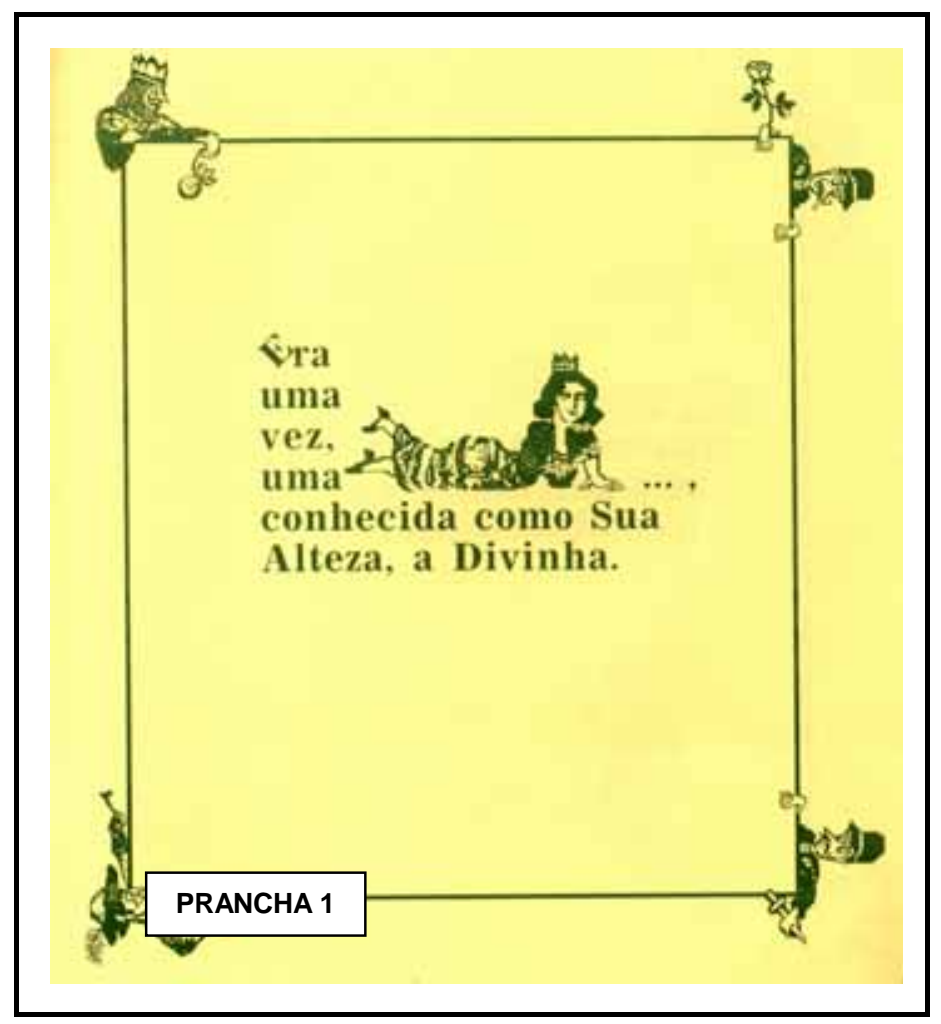

O período em que transcorre a ação isenta-se do aspecto cíclico. Desconhece-se o fator biológico; as mudanças ambientais e físicas não são assinaladas, não há o envelhecimento das personagens; um tempo que “... não altera a vida dos heróis, não acrescenta nada a suas vidas.” "Um dia (...) logo que o sol raiasse (...).”6 são referenciais que situam a ação, mas não informam, com precisão, a época em que se deram os fatos. Sabe-se que a personagem vai em busca do seu destino num dia ensolarado, de verão. "Lá pela terceira montanha, sentiu sede (...). Viu um coqueiro, (...) apanhou um coco e tomou água de coco.”7

Denominado por Bakhtin de “tempo de aventuras”, , o período de viagem da personagem é marcado por breves momentos casuais.

Quando deixa sua aldeia que poderia ser “... um sítio retirado, com uma casinha modesta, telha vã, rio de um lado, e de outro lado a floresta.” ${ }^{9}$,em

\footnotetext{
5 BAKHTIN, Mikhail. Questões de Literatura e de Estética. p.216.

6 LAGO, Angela, Sua Alteza A Divinha. p.4.

7 Idem, ibidem, p.12.

8 BAKHTIN, Mikhail, op. cit., p.219-20.

9 PIRES, Cornélio. Selecta Caipira. São Paulo, Livraria Liberdade, 1929, p. 115.
} 
direção ao palácio, Louva-a-deus, segundo informa o narrador, leva consigo uma “rosca envenenada”, presente de sua antagonista, a vizinha. Percebendo as intenções da audaciosa velhinha, a personagem atira a rosca para um cachorro. A partir dessa "concomitância fortuita" ${ }^{10}$, instalam-se, na narrativa, novas seqüências temporais, em cadeia, que vão governar a vida da personagem, favorecendo a sua performance. Assim, o cachorro envenenado é devorado pelos urubus que também sucumbem, salvando, indiretamente, a vida do herói. A casualidade, “ ... pela intrusão das forças irracionais (...).”11 também responde pelo suprimento das necessidades básicas de alimentação de Louva-a-deus. "Bateu um vento e caiu, em cima da manta, um ninho com sete ooooooovos de passarinho." ${ }^{12}$ A utilização do livro de orações, como meio de propagação e sustentação do fogo, na preparação dos ovos é, igualmente providencial, como também o coqueiro encontrado “...lá pela terceira montanha (...). ${ }^{13} \mathrm{O}$ acaso, então, representa, neste tempo de aventuras, o meio de ruptura no curso normal dos fatos. De acordo com o conceito proppiano, mais propriamente, na esfera da ação, a providência, simbolizada pelo caminho ou, especificamente no conto, pela floresta, será o doador(a), aquele(a) que irá beneficiar o herói que parte, em percurso solitário, visando o cumprimento de uma tarefa.

Vinculada ao aspecto mágico, a floresta caracteriza-se na obra, como um espaço de colheita, de provisão. Este caminho-floresta é o lugar ideal à intrusão do acaso que responderá pelo curso dos acontecimentos.

O elemento árvore que se dimensiona, à medida que a personagem aproxima-se do castelo, torna-se referencial porque define, com exatidão, o local da competição e auxilia na organização temporal-seqüencial da ação.

Esta presença personificada, cuja inclinação dos galhos sugere movimento e, o vento, anunciando a chegada da chuva “... depois da segunda mon-

\footnotetext{
${ }^{10}$ BAKHTIN, Mikhail. Questões de Literatura e de Estética. p.218.

${ }^{11}$ BAKHTIN, Mikhail, loc. cit.

${ }^{12}$ LAGO, Angela. Sua Alteza A Divinha. p.10.
} 
tanha começou a chover."14, indicam que houve uma seqüência temporal (sol, vento, chuva) e espacial, marcada pelo caminho, através da paisagem e seus elementos (pássaros, coqueiros, cachorro, árvore, etc) dentro do tempo de aventuras.

Entretanto, a página que mostra a floresta, entrecortada pelas montanhas, não é o palco de disputa entre a princesa e o plebeu, mas é a via, a estrada que levará ao encontro das personagens. ${ }^{15}$

O motivo que conduz Louva-a-deus ao palácio - o encontro com a princesa pela declinação das adivinhas -, está estritamente relacionado ao "cronotopo da estrada." ${ }^{\text {, }}$, que deve ser entendido como um meio facilitador do encontro. É de fundamental importância o contato entre as personagens, porque é através dessa cronotipicidade que o destino do aldeão será traçado.

O castelo, especificamente a sala principal, é o lugar destinado à ação. Por ser considerado um ambiente naturalmente reservado às solenidades, exibições de danças, apresentações teatrais, etc., será o local onde ocorrerá o desfecho e a conclusão da narrativa.

De modo geral, todo castelo, aos olhos de um leitor de hoje, impressiona pelo grau de historicidade que possui. Entendido como um registro vivo do tempo passado, ele conserva marcas das gerações que por ali viveram. Os castelos tinham suas portas abertas para os artistas, particularmente os envolvidos com a música e a palavra. A tradição histórica tem mostrado, por outro lado, que a despeito da solidez de sua construção e conseqüente sugestão de poder e impenetrabilidade, os castelos foram invadidos e tornaram-se palco de confrontos entre a nobreza e o povo. A presença do castelo, na obra, pode ser interpretada

\footnotetext{
${ }^{13}$ Idem, ibidem, p.12.

${ }^{14}$ LAGO, Angela. Sua Alteza A Divinha. p.9.

${ }^{15}$ De acordo com a mentalidade medieval o deserto, assim como a floresta, simbolizavam o lugar de encontro com os demônios, com o terror, com as aparições. Não somente refúgio para bandidos, assassinos e aventurei ros, a floresta, igualmente, representava a morada dos eremitas ocultos que fugiam à civilização. Mais detalhes sobre este assunto, consultar Jacques Le Gof em Imaginário Medieval. Trad. Manuel Ruas. 3.ed. Portugal, Es tampa, 1994.

${ }^{16}$ BAKHTIN, Questões de Literatura e de Estética. p.223.
} 
como uma fusão entre o tempo e o espaço; naquele hiato espaço-temporal ocorreu um evento significativo - o confronto entre um membro da nobreza e um representante do povo. É interessante notar que em situações históricas notáveis, é sempre o povo, na figura do fraco, do marginalizado socialmente que vai, em situações-limites ao castelo enfrentar e vencer o nobre, o forte, o poderoso.

O entremear do elemento histórico com o elemento social, entendido no conto, como a competição de vida ou morte, que visa à escolha, balizada nos protocolos políticos e estatais, de um noivo para a princesa faz eclodir na mente do leitor significados como a importância do líder para a comunidade, a estabilidade conjugal, a renovação, a distinção entre classes sociais, mas, principalmente, o tempo folclórico, integrado no seu curso de vida, que carrega no seu bojo as tradições - mitos, ritos, costumes, de fácil reconhecimento porque estão embrenhados nas fissuras da existência humana.

A percepção do tempo folclórico, por parte do leitor, não se dá de forma abstrata, e sim pela própria contigüidade dos fenômenos peculiares do imaginário medieval, representados pelas festas rituais, proposições de enigmas, adivinhas - aspectos resgatados na obra.

Particularmente, o hábito de adivinhações esteve sempre presente na vida do homem, expressando-se nas mais variadas técnicas. Mandalas, oráculos, círculos ou esferas contendo desenhos simbólicos, números matemáticos, datas, eram amplamente usados para ditar a sorte do interrrogado. Na África, por exemplo, quando alguém queria saber se uma viagem seria bem sucedida ou não, bastava consultar um feiticeiro que este jogava, em um círculo traçado no chão, ossos de galinha. Segundo a disposição dos ossos, o indivíduo saberia se deveria ou não empreender a viagem. Na China, até 1960 era comum a prática do "I Ching”, muito apreciado pela população, que consistia numa espécie de orácu$10^{17}$, onde sacerdotes lançavam moedas como meio de obtenção de respostas às

\footnotetext{
${ }^{17}$ Sobre “I Ching” consultar FRANZ, Marie- Louise Von. Adivinhação e Sincronicidade. Trad. Álvaro Cabral,
} 
perguntas formuladas pelos interessados.

Cascudo argumenta que: "Não se encontrou negro, amarelo, vermelho, branco, furta-cor sem o conhecimento pelas adivinhas e o encanto em propôlas e resolvê-las.” ${ }^{18}$ Esses motivos, que alicerçaram a sociedade primitiva, entrecruzam-se às peculiaridades da sociedade moderna para referenciarem acontecimentos da vida humana, e traçarem linhas de comportamento.

\subsection{O lúdico no adivinhar}

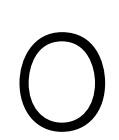

jogo, como já foi mencionado anteriormente, como função cultural e social, expressa traços da vida do homem comum, habituado aos rituais, às competições, às atividades ligadas ao relaxamento, à descontração e ao riso espontâneo.

Para o homem medievo, acostumado às narrativas orais, a preservação da boa memória significava sabedoria e poder. Nos rituais de proposição de enigmas, quando o conhecimento do indivíduo era colocado em prova, a participação da comunidade era efetiva, pela oportunidade de entreter-se e tomar parte como testemunha ocular, no espetáculo que avaliaria a capacidade do candidato. “O enigma ou, em termos menos específicos, a adivinhação, é, considerando à parte seus efeitos mágicos, um elemento importante das relações sociais.”19 , salienta Huizinga:

\footnotetext{
“O enigma é uma coisa sagrada cheia de um poder secreto e, portanto, é uma coisa perigosa. Em seu contexto mitológico ou ritualístico, ele é quase sempre aquilo que os filólogos alemães chamam de 'Halsrätel' ou 'enigma capital', em que se arrisca a cabeça caso não se consiga decifrá-lo. A vida do
}

São Paulo, Cultrix, 1980, p.7-10 passim.

${ }^{18}$ CASCUDO, Luis da Camara. Literatura Oral no Brasil. 3.ed. Belo Horizonte, Itatiaia, 1984, p.65.

${ }^{19}$ HUIZINGA, Johan. Homo Ludens. Trad. João P. Monteiron 4.ed. São Paulo, Perspectiva, p.125. 
jogador está em jogo.”20

O autor também elucida que “... à medida que a civilização vai evoluindo, o enigma bifurca-se em dois sentidos diferentes: de um lado a filosofia mística e de outro o simples divertimento.”21.

Se para Huizinga o enigma, de modo geral, consiste em uma espécie de adivinha, elemento que penetra o universo do sagrado, do simbólico, Jolles a considera uma forma de expressão oral que tem por base a formulação de uma questão de difícil solução. Ambos os teóricos, entretanto, concordam com os objetivos e as implicações da prática de adivinhações.

“Na Adivinha, (...) há um homem que interroga outro homem e de modo tal que a pergunta obriga o outro a um saber. Um dos dois possui o saber, é a pessoa que sabe, o sábio; um inter locutor o enfrenta e é levado, pela pergunta, a pôr em jogo suas forças, seus recursos e sua vida, para chegar a possuir também o saber e apresentar-se ao outro como sábio. Tal saber está presente desde o momento em que a pergunta foi formulada e não existe, (...) meio de arrancar, a uma pergunta, sua resposta.,22

Na adivinha, esclarece Jolles, sem nos adentrarmos aqui na questão "Forma Simples", aspecto que o autor persegue no seu estudo sobre oralidade, o indagado sofre opressão, sente-se constrangimento pelo inquiridor que, antecipadamente, conhece a resposta e por isso desnuda o candidato deixando-o vulnerável, muitas vezes, ao público. Jolles descreve o interrogador como aquele “... que possui o saber e a que chamamos sábio, (...) como um ser ‘demoníaco’; ele é, ao mesmo tempo, um monstro que nos apavora, que nos oprime e nos sufoca.”23

\footnotetext{
${ }^{20}$ HUIZINGA, Johan. Homo Ludens. p.123.

${ }^{21}$ Idem, ibidem, p.125.

22 JOLLES, André. Formas Simples. Trad. Álvaro Cabral. São Paulo, Cultrix, 1976, p.111-12.

${ }^{23}$ JOLLES, André. Formas Simples. p.113.
} 
Na narrativa, o conceito atribuído ao jogo acentua-se através da personagem Louva-a-deus, que, embora vivencie momentos de tensão - "agora o quadro está preto ...”24, sente prazer e tira proveito da situação, independente do resultado da empreitada, perante o espectador que valoriza a sua disposição e coragem, declinando-lhe aplausos esfuziantes. Ainda nas palavras de Huizinga:

“ Um dos mais fortes incentivos para atingira perfeição, tanto individual quanto social, e desde a vida infantil até aos aspectos mais elevados da civilização, é o desejo que cada um sente de ser elogiado e homenageado por suas qualidades. Elogiando o outro, cada um elogia a si próprio. Queremos ser honrados por nossas virtudes, queremos a satisfação de ter realizado corretamente alguma coisa. Realizar corretamente uma coisa equivale a realizá-la melhor que os outros. Atingir a perfeição implica que esta seja mostrada aos outros; para merecer reconhecimento, o mérito tem que ser manifesto. A competição serve para cada um dar provas de sua superioridade. E isto se verifica principalmente na sociedade primitiva."25

O aplauso consiste num ritual que faz parte de qualquer jogo, além do que, é uma forma de gratidão, pois o jogador, não somente proporciona diversão, e neste particular, o riso, mas representa o desejo incrustado de vitória alimentado pela platéia.

Ainda que todo combate situe-se fora do real, que signifique uma evasão da vida cotidiana, o elemento em pauta no jogo, inserido na narrativa, ainda é a vida de Louva-a-deus, o bem real de maior valor da personagem.

Em toda competição, subentende-se ou força física, qualidades do

\footnotetext{
${ }^{24}$ LAGO, Angela. Sua Alteza A Divinha. p.19.

${ }^{25}$ HUIZINGA, Johan. Homo Ludens. p.71-2.
} 
corpo ou inteligência e astúcia, como valores do espírito.

Louva-a-deus aspira ao êxito, mas o seu esquema tático de ataque, contudo, não está traçado. O percurso até o castelo, marcado pelas surpresas, impedem-no de formular ou relembrar as adivinhas que proporia ao adversário. O aldeão não possui o conhecimento das formalidades necessárias para enfrentar um desafio previamente ensaiado, mas possui outros atributos conquistados pela vivência no seu meio social, além da experiência adquirida durante seu trajeto até o castelo, em que vários imprevistos o favoreceram, como forma de defesa contra as armas de A Divinha. A solução para as adivinhas, citando Jolles, será “... a fórmula, a palavra de passe, que dá acesso a um domínio fechado.”26, ao do conhecimento. O sucesso é conquistado, quando Louva-a-deus faz uso desses atributos: criatividade e improvisação no instante do desafio. Desse modo se torna apto a penetrar o mundo de A Divinha, conquistar o coração da princesa. Através do comportamento, aparentemente despojado, Louva-a-deus, como detentor do conhecimento, provou, ao entrar no castelo, que dominava, justamente, a força da oralidade, no que diz respeito a sua graça, leveza, versatilidade, possibilidades de se amoldar a situações diversas. Enfim, Louva-a-deus formulou suas adivinhas baseado na experiência do caminho; versátil, trouxe seu próprio cenário: a praça, o público, o povo, quem de fato possui o poder de improvisar, de surpreender, de inovar, provocando mudanças até mesmo, - ou principalmente nos rígidos códigos lingüísticos.

A vitória também vai significar a renovação sócio-cultural, a salvação da personagem que passa a estreitar, desde o momento da ovação, durante a competição, relações de amizade, respeito e liderança com o grupo social a que pertence. Neste aspecto são apropriadas as considerações de Huizinga ${ }^{27}$ quando define o jogo como sendo “... mais do que um fenômeno fisiológico ou um reflexo psicológico.”, mas uma “função significante”, aquela que determina a “...

\footnotetext{
${ }^{26}$ JOLLES, André. Forma Simples. p.116.
} 
presença de um elemento não material em sua própria essência.”

\subsection{Oralidade como linguagem}

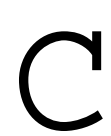

oncernente à linguagem, trata-se de uma narrativa de estrutura sim-

plificada. O uso reiterado de vocábulos e frases, subtraídos da oralidade, facilitam a assimilação do texto. "Eta vizinha! Disse o Louva-a-deus e continuou o camin PRANCHA 1 deus poderia desistir no meio do caminho ....”28.

O desalinho das sentenças indicia a ação das personagens. A seqüência ilustrativa que se refere ao conteúdo textual, conforme mostra a prancha número 2

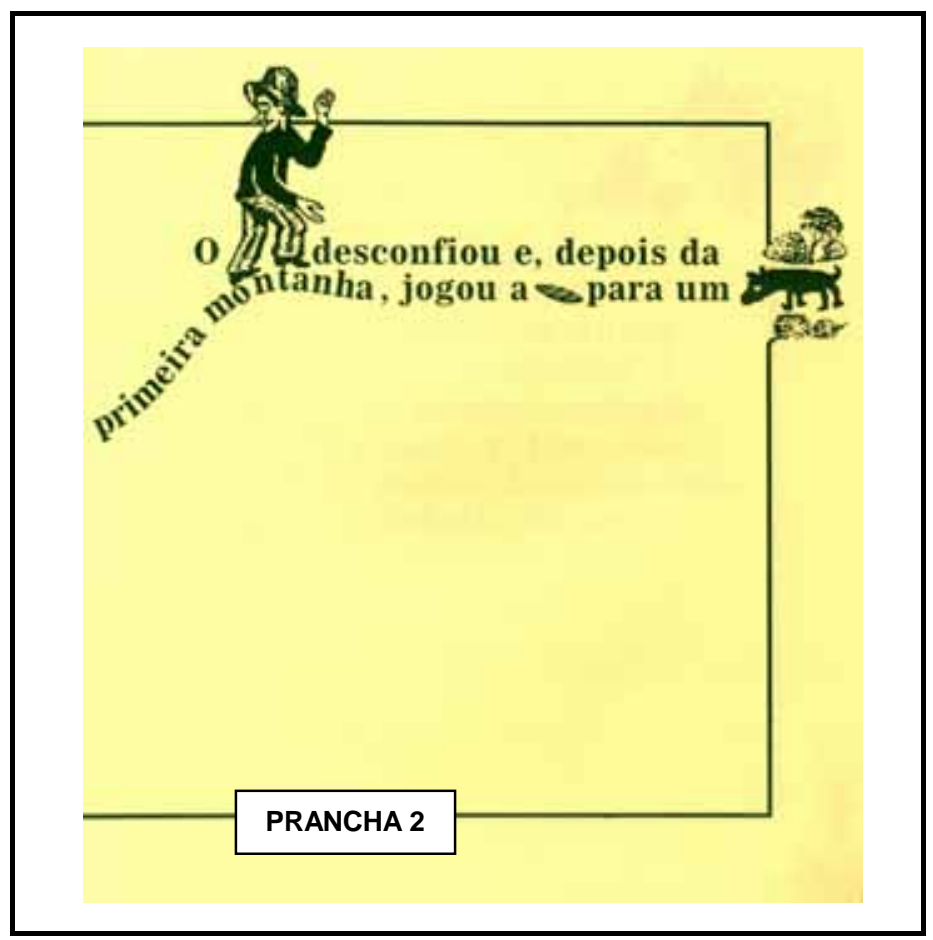

e que exibe o esboço de Louva-a-deus, subindo a primeira montanha, mostra o texto disposto de modo inclinado, insinuando a curvatura de uma elevação e conferindo movimento ao livro. A cena que se refere às personagens enforcadas,

${ }^{27}$ HUIZINGA, Johan. Homo Ludens.p.3.

${ }^{28}$ LAGO, Angela. Sua Alterza A Divinha. p.9. 
exemplificada através da prancha número 3, igualmente, encontra ressonância no código verbal. "Não era fácil. E quem não conseguisse, forca!”29

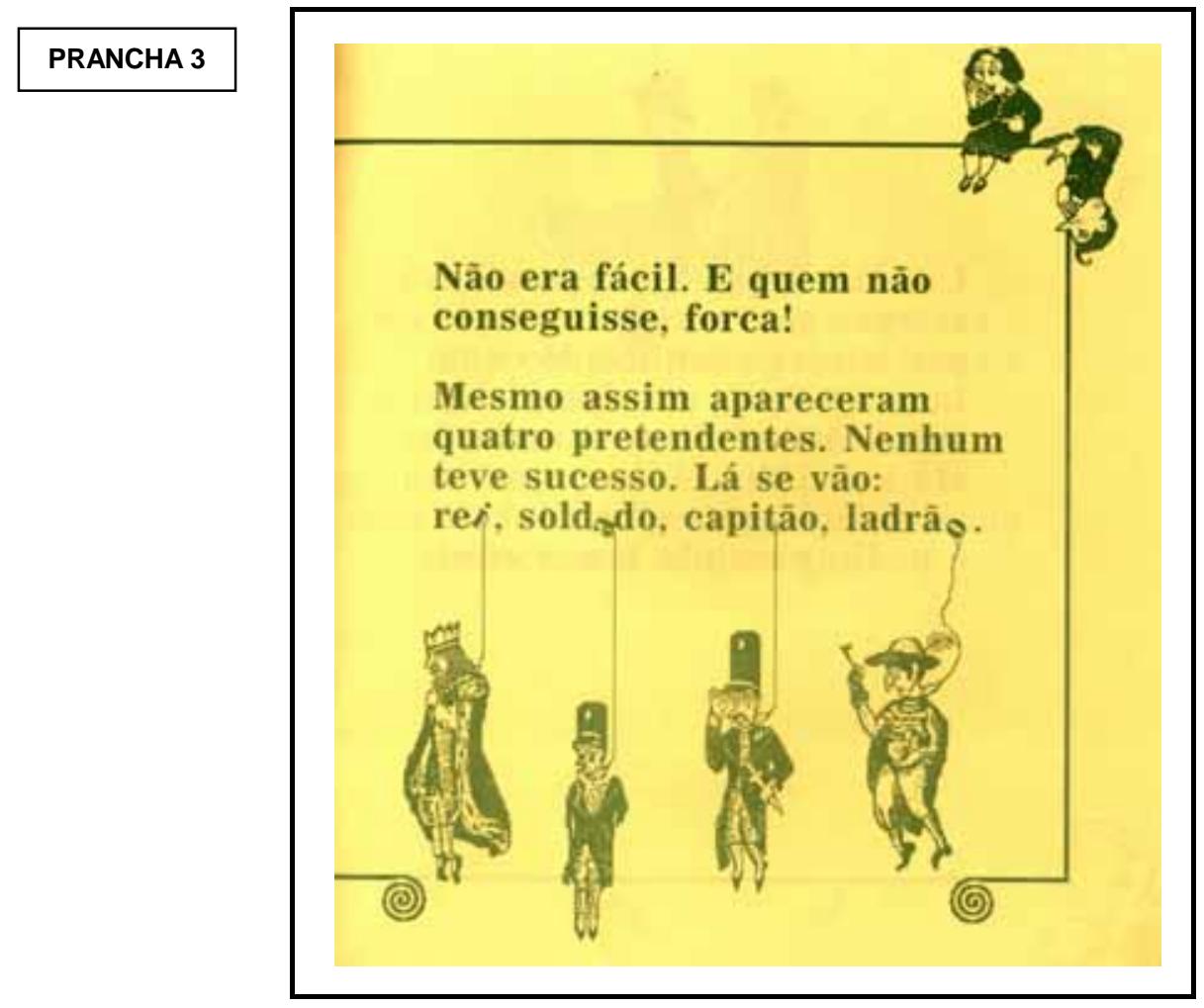

Amparados pelo caráter organizacional, estão quatro personagens suspensos pela forca, centralizados na página. A extensão da corda sustenta-se nos vocábulos: rei, soldado, capitão e ladrão, desordenando-os. O recurso operante visa à transformação textual da letra, desarticulada do vocábulo, em ilustração, insinuando o suporte, a escora da forca que sofre ligeira inclinação, dada a força do elemento suspenso.

A ludicidade presente no quadro alicerça-se no resgate de fundamentos do acervo popular que tratam de aspectos culturais, trazidos ao longo dos anos, através do ato de contar e recontar. São costumes, crenças, brincadeiras e cantorias, componentes que alinhavam períodos da História, conservados pela tradição oral, pela memória dos mais experientes, que orgulhosamente comunicam, através do tempo, um manancial significativo de informação e conheci-

\footnotetext{
${ }^{29}$ LAGO, Angela. Sua Alteza A Divinha. p.15.
} 
mento.

A composição remete-nos, ainda, a uma parlenda - passatempo infantil muito divulgado entre as meninas - que geralmente é praticada antes de se iniciar um jogo qualquer, para se escolher, por exemplo, “com quem estará o jogo”, ou seja, quem ficará por último, quem será o pegador, quem ficará no papel difícil da brincadeira. Geralmente, as candidatas a participar do jogo ficam alinhadas em frente a uma criança que irá apontando o dedo indicador para cada uma delas e repetindo a fala "rei, capitão, soldado, ladrão, moço bonito do meu coração”. Cada criança recebe, então, uma palavra, que lhe designa um destino na brincadeira. A criança que se vê apontada, quando a parlenda chega à palavra coração, sente-se aliviada, pois ela foi a escolhida para sair da fila, não sofrerá, no caso, a punição de ser a última e cumprir uma tarefa indesejada. A parlenda se repete até que a seleção da candidata - quem sobrar - se concretize. Pode ocorrer, também, o inverso, dependendo do grupo que utiliza a parlenda. A criança apontada com o dedo no momento em que se ouve o final da parlenda, pode ser a que ficará com a parte indesejada no contexto do jogo. De qualquer modo, a prática dessa parlenda se destina à eliminação de candidatas num jogo e à escolha conseqüente da que será premiado. ${ }^{30}$

Observa-se que a ilustração, objeto de nossas considerações, mostra na corda somente quatro elementos da parlenda a que vimos nos referindo: rei, capitão, soldado e ladrão. A ilustração deixa evidente que esses candidatos já foram eliminados do jogo disputado com A Divinha, assim como abre um espaço amplo para a indagação: Onde está o quinto elemento: “o moço bonito do meu coração?” No contexto em que a narrativa se desenvolve pode-se dizer que ele está a salvo e que se trata de Louva-a-deus. Todos já estão na forca, porque foram perdedores; o que escapará da morte será o vitorioso, o escolhido pelo jogo, “o moço bonito”, com quem a princesa se casará.

\footnotetext{
${ }^{30}$ Em outra versão tradicional essa parlenda consiste na criança ir apontando para os botões de sua blusa - cada
} 
O jogo sonoro, produzido pela repetição dos vocábulos da parlenda e, principalmente, seu uso nas brincadeiras infantis, na seleção dos envolvidos na brincadeira - o que não deixa de ser uma disputa - consagram o alcance da oralidade na composição do texto de Angela Lago.

A representação dos “ooooooovos”, caídos sobre a manta de Louvaa-deus, indica a versatilidade de Angela Lago quanto a detalhes da ilustração. Apropriando-se do vocábulo “ovo”, através da reiteração da letra “o”, a artista indica o número exato de ovos caídos do ninho, sem precisar recorrer, naquele momento, ao elemento pictórico; razão que não a isenta de usar, em outras seqüiências, o signo visual, em substituição à palavra, para elucidar uma idéia e potencializar a leitura do leitor iniciante. "Só caso com quem fizer (...) adivinhações que eu não adivinhe e que adivinhe três que eu fizer." ${ }^{31} \mathrm{O}$ traço virando palavra e o texto transformando-se em imagem, é como o rio e seus afluentes que permitem o paralelismo, mas jamais a separação (vide prancha número 4). 


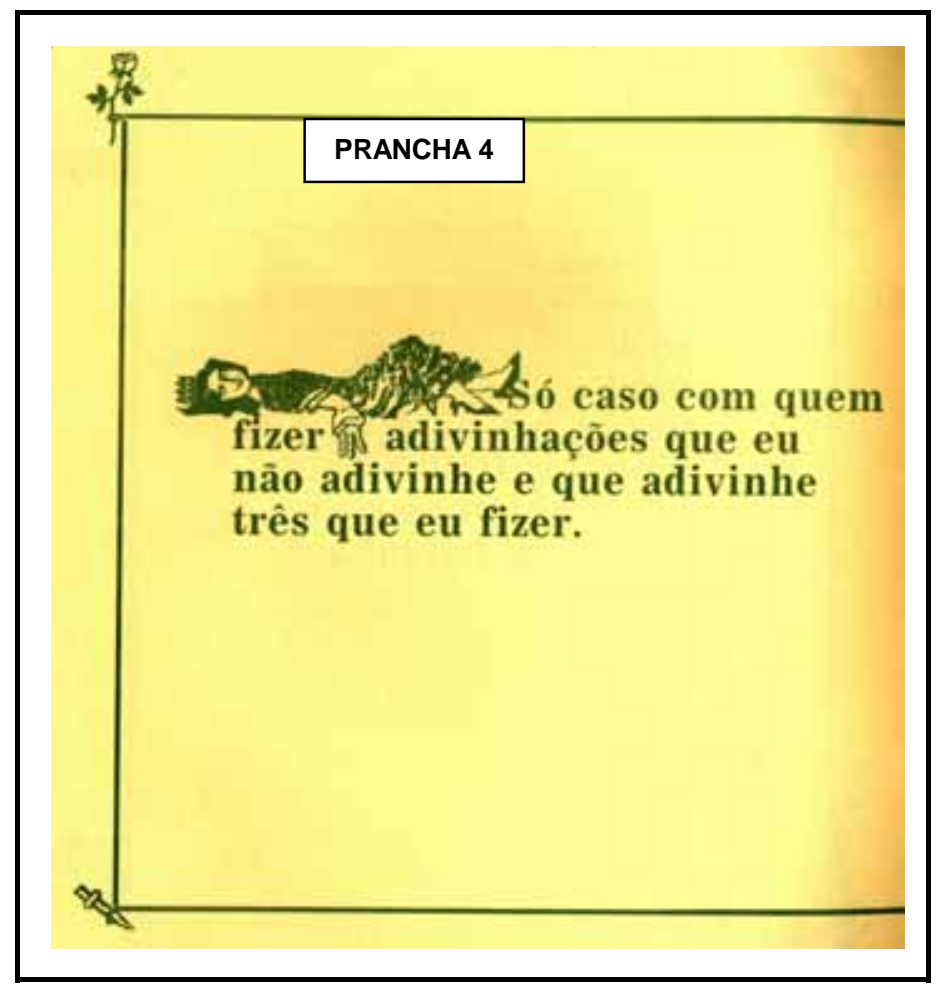

É a ilustração dimensionando-se, reproduzindo o contar, corporificando, descrevendo a palavra, informando, através da função pedagógica, que Góes ${ }^{32}$ denomina de "proposta Informativo-Lúdica - (...) o livro tem como proposta passar uma informação, dar uma lição, sim, mas o faz de forma artística, lúdica, ótima.,33 aproximando, dessa forma, o leitor que percebe e capta traços e cores.

Referente ao grau de percepção do leitor criança perante o livro ilustrado, ensina-nos Benjamim que:

"Não são as coisas que saltam das páginas em direção à criança que as contempla - a própria criança penetra-as no momento da contemplação, como nuvem que se sacia com o esplendor colorido desse mundo pictórico. Frente ao seu livro ilustrado a criança coloca em prática a arte dos taoístas consumados: vence a parede ilusória da superfície e, esgueirando-se entre tapetes e bastidores coloridos, penetra em um pal-

\footnotetext{
${ }^{32}$ GÓES, Lúcia Pimentel. Olhar de Descoberta. Ilustração Eva Furnari. São Paulo, Mercuryo, 1996, p.69.

${ }^{33}$ Idem, ibidem, p.70.
} 
co onde o conto de fadas vive. (...) Nesse mundo permeável, adornado de cores, onde a cada passo as coisas mudam de lugar a criança é recebida como companheira." ${ }^{\text {34 }}$

A literalidade das respostas atribuídas às adivinhações, em sentenças como, “Louva-a-deus está apertado”35, “ o quadro está preto”36, possui conotação diversa. Como códigos de sinalização, as palavras, que também fazem parte do jogo, dentro do universo do poético, expresso pela obra, geram outros significados, pois a linguagem poética joga com as palavras, modifica-as, ordena-as, sempre com a intervenção do elemento lúdico. Atribuir à palavra a força reveladora, implica transformação. O uso reiterado da palavra conduz à solução das adivinhas que, entrelaçadas ao enredo, respondem pela preservação da vida de Louva-a-deus.

Pensando-se então, a respeito da produção interativa do signo, palavra e imagem intercambiam-se na teia narrativa, para gerar significados que o leitor, paulatinamente, desbrava através do olhar que se demora atento e crítico sobre a obra.

Quanto ao texto visual, este desvela uma personagem de aspecto tenso, dada a sua postura. A personagem, com uma das mãos levantadas, referencial que poderia sugerir um momento de espera, a outra mão ocultando os olhos - indícios de concentração e reflexão e as pernas, entreabertas com os pés voltados para dentro dos joelhos, expressa a não preocupação com a aparência. A falta de apuro na gesticulação refere-se ao nervosismo gerado pelo momento derradeiro pelo qual vive Louva-a-deus; razão que o levaria a asseverar: “- Ninguém sabe que eu sou um adivinhador de (...).”37 (vide prancha número 5).

\footnotetext{
${ }^{34}$ BENJAMIN, Walter. Reflexões: A Criança O Brinquedo A Educação. Trad. Marcus V. Mazzari. São Paulo, Summus, 1984, p.55.

${ }^{35}$ LAGO, Angela. Sua Alteza A Divinha, p.17.

${ }^{36}$ Idem, ibidem, p.19.

${ }^{37}$ LAGO, Angela, op. cit., p. 21.
} 


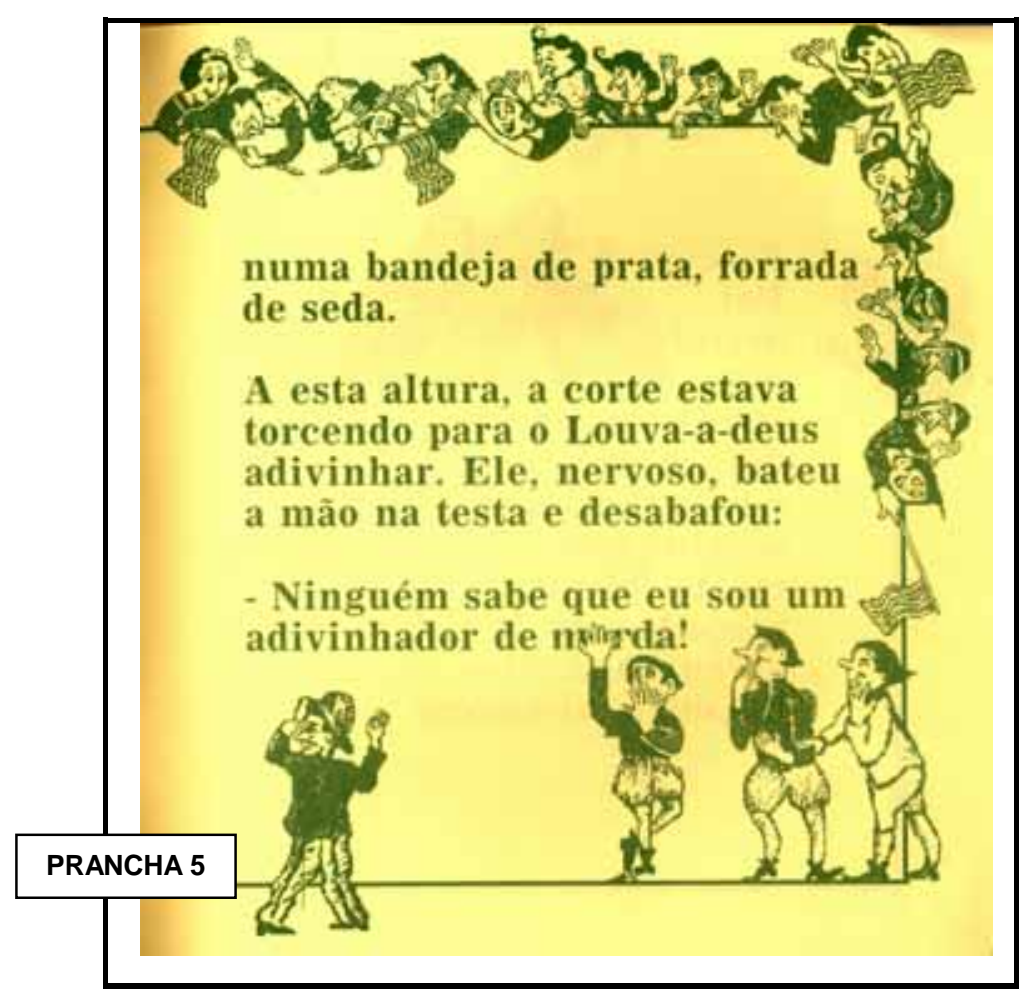

O caráter extra oficial, a descontração e a liberdade da praça pública, dentro do período medieval, como bem assinala Bakhtin ${ }^{38}$, são elementos dos quais pode-se subtrair esse comportamento privado de rigores, que traçam o perfil de Louva-a-deus, fator que justificaria a adoção da gestualidade e da linguagem rude, avessas aos padrões convencionais, pregados pela Igreja e pelo Estado vigentes da época. Esclarece Bakhtin que:

“... a cultura popular não oficial dispunha na Idade Média e ainda durante o Renascimento de um território próprio: a praça pública, e de uma data própria: os dias de festa e de feira. Essa praça entregue à festa, (...) constituía um segundo mundo especial no interior do mundo oficial da Idade Média. Um tipo especial de comunicação humana dominava então: o comércio livre e familiar. Nos palácios, nos templos, nas instituições, nas casas particulares reinava um princípio de comunicação hierárquica, uma etiqueta, regras de polidez. Discur-

\footnotetext{
${ }^{38}$ BAKHTIN, Mikhail. Cultura Popular na Idade Média e no Renascimento. 4.ed. Trad. Yara Frateschi, São Paulo-Brasília, Edunb, 1999, p.132.
} 
sos especiais ressoavam na praça pública: a linguagem 'familiar’, que formava quase uma língua especial, inutilizável em outro lugar, nitidamente diferenciada da usada pela Igreja, pela corte, tribunais, instituições .públicas, pela literatura oficial, da língua falada das classes dominantes (aristocracia, nobreza, alto e médio clero, aristocracia burguesa), embora o vocabulário da praça pública aí irrompesse de vez em quando, sob certas condições."39

Na condição de plebeu, Louva-a-deus possui familiaridade com a linguagem própria das feiras, com o ambiente das apostas, das encenações freqüentes nos tablados, ${ }^{40}$ com os jogos de palavra, dentre eles, a prática de adivinhações. Dentro deste contexto está inserido o carnaval, manifestação popular que:

“... representava muito mais, naquela época, do que a mera cessação do trabalho produtivo; representava uma cosmovisão alternativa caracterizada pelo questionamento lúdico de todas as normas. O princípio carnavalesco abole regras e restrições convencionais. Durante o carnaval, tudo o que é marginalizado e excluído, o insano, o escandaloso, o aleatório se apropria do centro, numa explosão libertadora. O princípio corpóreo material - fome, sede, defecação, copulação - tornase uma força positivamente corrosiva, e o riso festivo celebra uma vitória simbólica sobre a morte, sobre tudo o que é considerado sagrado, sobre tudo aquilo que oprime e restringe.”41

\section{A festa do carnaval, realizada na praça pública, significava deixar o}

\footnotetext{
${ }^{39}$ BAKHTIN, Mikhail. A cultura Popular na Idade Média e no Renascimento. p.133.

${ }^{40}$ É importante ressaltar que toda essa produção cultural, realizada nas praças públicas, contava, igualmente, com a presença e participação ativa do elemento feminino, como informa ZUMTHOR em A Voz e a Letras. Trad. Amálio Pinheiro; Jerusa P. Ferreira. São Paulo, Companhia das Letras, 1993, p.63.

${ }^{41}$ STAM, Robert. Bakthin. Da Teoria Literária à Cultura de Massa. Trad. Heloísa Jahn. São Paulo, Ática, 1992, p.43.
} 
mundo de "pernas para o ar” - concordar, discordar, ironizar, protestar, infringir. A praça era considerada o local da extra-oficialidade, da liberdade, da alegria e do prazer.

Portanto, a postura de Louva-a-deus - o descuido na gesticulação e linguagem, verificado quando do questionamento da princesa, poderiam exprimir excitação da personagem diante do embaraço, mas também poderia ser entendido, como mais um ato de improvisação, de brincadeira, de ruptura de padrões, dado o caráter descompromissado da personagem, com regras e formalidades.

A simplicidade da personagem, entretanto, no momento do desafio, vai coadunar com a ansiedade da princesa em obter soluções para as adivinhações. Velado por um falso propósito, o caráter da princesa reveste-se de determinismo e moderado sadismo perante a sorte dos pretendentes. A espera pela resposta, principalmente da terceira adivinha, traduz-se na expectativa pelo futuro noivo e então, pela realização de seus sonhos de moça, aspecto muito bem sinalizado pela ilustração.

Disposta do lado direito e inferior da página 20, como mostra a prancha número 6,

\footnotetext{
PRANCHA 6
}

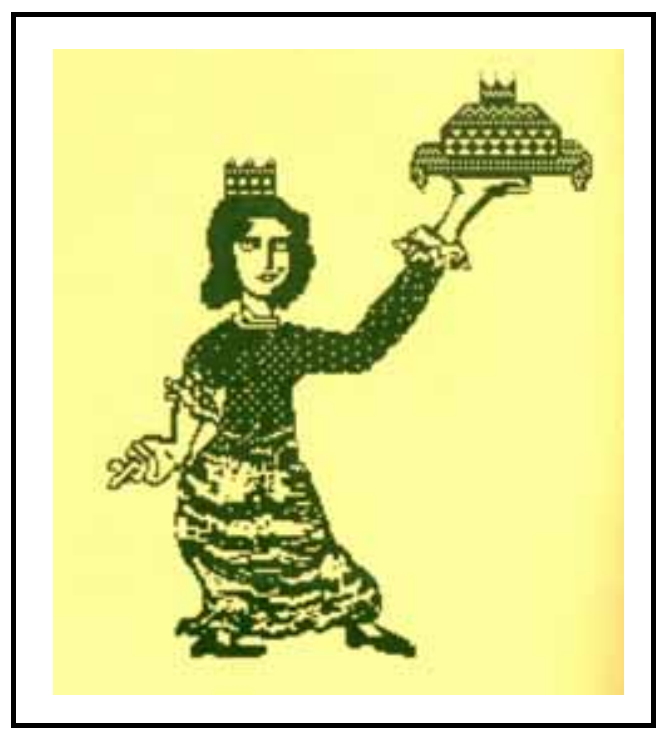

A Divinha sustenta, com a mão esquerda, a bandeja de prata com estrume de boi. 
O olhar estático e o sorriso brejeiro no canto dos lábios não escondem o seu ímpeto de vibrar positivamente em favor de Louva-a-deus, enfaticamente demonstrado pelos dedos cruzados da outra mão, ligeiramente ocultos, em sinal de sorte para o competidor. As respostas equivalem a diretrizes que firmam o destino de ambas as personagens.

As conotações atribuídas às expressões "Louva-a-deus está apertado, agora o quadro está preto" e "ninguém sabe que eu sou um adivinhador de ...”, ${ }^{2}$ estão em conformidade com o estado de espírito da personagem que, temendo a represália, pois as proposições possuem inúmeras possibilidades de erro, joga com toda a sua espontaneidade e obtém sucesso.

Ressaltamos, contudo, que nomear uma bandeja, contendo estrume de boi, como instrumento de adivinhação, causa estranheza, por tratar-se de um membro da nobreza, cujos hábitos e costumes figurariam como uma antítese do “realismo grotesco”, característico da praça popular.

Diante da primeira adivinha, Louva-a-deus suspira admitindo estar angustiado, pois naturalmente não possui a resposta. Na apresentação da segunda proposição, ele se dá conta de que a situação é-lhe um tanto desfavorável e deixa “escapulir” a expressão - “ o quadro está preto” - numa tentativa de retratar o instante de tensão e embaraço em que se encontra. Perante a caixa de estrume, que compõe a terceira adivinha, Louva-a-deus então exprime toda a sua aflição e desespero. Ao adotar uma conduta de total subestima, a personagem, por sua vez, serve-se da linguagem informal não com a intenção de acertar a resposta, mas para desabafar, aspecto que denota uma expectativa diversa daquela prevista pela Corte e pelo leitor. A utilização da linguagem grotesca faz parte do mundo da personagem. De acordo com Bakhtin:

\footnotetext{
"Pode-se dizer que toda a linguagem familiar dos clérigos (e
}

\footnotetext{
${ }^{42}$ LAGO, Angela. Sua Alteza A Divinha. p.21.
} 
de todos os intelectuais da Idade Média) e do povo estava profundamente impregnada pelos elementos do 'baixo' material e corporal: obscenidades e grosserias, juramentos, textos e sentenças sagradas correntes travestidas e viradas do avesso; tudo que entrasse nessa linguagem, devia obrigatoriamente submeter-se à força degradante e renovadora do poderoso 'baixo’ ambivalente.”43

A princesa, participante dessa cultura cômica popular, não se surpreende com a resposta de Louva-a-deus. A utilização do estrume, como opção da adivinha assegura a sua perfeita identificação e interação com o realismo do "baixo material e corporal."

O emprego de uma linguagem considerada rude na resposta à última adivinha assegura a vida de Louva-a-deus, não propriamente pela utilização da expressão deselegante em si, mas porque ele pôde externar, num momento de conflito, suas características mais arraigadas que o definem e o posicionam como indivíduo que carrega a tradição, a sabedoria popular. Ainda quanto à imagem dual dos excrementos, na Idade Média, é bastante elucidativa a citação de Bakhtin:

"As imagens dos excrementos e da urina são ambivalentes como todas as imagens do 'baixo' material e corporal: elas simultaneamente rebaixam e dão a morte por um lado, e por outro dão à luz e renovam; são ao mesmo tempo bentas e humilhantes, a morte e o nascimento, o parto e a agonia estão indissoluvelmente entrelaçados." ${ }^{44}$

As adivinhações, enquanto elemento propulsor da narrativa, podem ser entendidas como canais de comunicação entre o narrador, o espectador e ou

\footnotetext{
${ }^{43}$ BAKHTIN, Mikhail. A Cultura Popular na Idade Média e no Renascimento. p.75.

${ }^{44}$ Idem, ibidem, p.130.
} 
leitor, proximidade que lhes garante cumplicidade.

Toda adivinha possui uma cifra, um segredo que pertence ao interrogador ou a uma sociedade fechada e que, necessariamente, conta com certo tipo de linguagem, denominada segundo Jolles, de especial. “Toda a língua cujo conhecimento indica filiação num círculo fechado e significa, na clandestinidade desse círculo, o sentido do universo, é por nós denominada língua especial.”45 Acessar essa linguagem significa estar de posse de um elemento exclusivo do grupo. No caso de Louva-a-deus trata-se novamente do elemento acaso promovendo o êxito do herói. Adentrar a um círculo desconhecido e tentar desvendar a proposição aguça, na narrativa, o interesse do leitor que, ávido de curiosidade, passa a investigar as possíveis respostas e as probabilidades de acerto, traçando, dessa forma, o destino de Louva-a-deus.

A resolução, que pode ser ou não verdadeira, é conseguida por associação de idéias. As palavras empregadas na elaboração da cifra, via de regra, possuem significado diverso daquele usado na linguagem comum.

Em relação à disposição natural da platéia, assim como também do leitor participativo, em apoiar Louva-a-deus, o que se percebe é uma clara tendência ao justo, ao desejo de restabelecimento do equilíbrio, postura que Jolles denomina de moral ingênua. No conto em questão, perante o obstáculo imposto à personagem “... o nosso sentimento de justiça [do leitor e da platéia] foi perturbado por um estado de coisas (...) e que uma outra série de incidentes e um acontecimento de natureza peculiar satisfizeram em seguida esse sentimento, voltando tudo ao equilíbrio.”46

Para Jolles, "o conto escolhe, de preferência, os estados e os incidentes que contrariem o nosso sentimento de acontecimento justo.”47 - Em Sua Alteza A Divinha o que se vê é a perturbação de Louva-a-deus perante o questio-

\footnotetext{
45 JOLLES, André. Formas Simples. p.121.

${ }^{46}$ Idem, ibidem, p.199.

47 JOLLES, André, op. cit., p.201.
} 
namento.

\subsection{Os olhos que vêem}

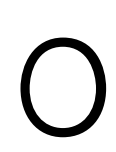

texto visual, em Sua Alteza A Divinha, constrói-se a partir da recuperação de aspectos que remetem a usos e costumes do período medieval. O objetivo da autora é dotar a ilustração de características tais como estilo de roupas, sapatos e revelar, através do vestuário, “... um código de estatuto social ...” 48 mantendo, porém, a atualidade do trabalho - desenho-digitalizado, ponto a ponto, até a obtenção da imagem; processo compreendido “... entre a mão e a máquina, o artesanal e o técnico-industrial, do produto único à multiplicidade da reprodução técnica.”, ensina-nos Oliveira e Palo ${ }^{49}$

O alinhamento e a proximidade dos componentes pictóricos são parâmetros organizacionais que auxiliam na sustentação da composição. Demonstrada na prancha número 7 está a princesa,

PRANCHA 7

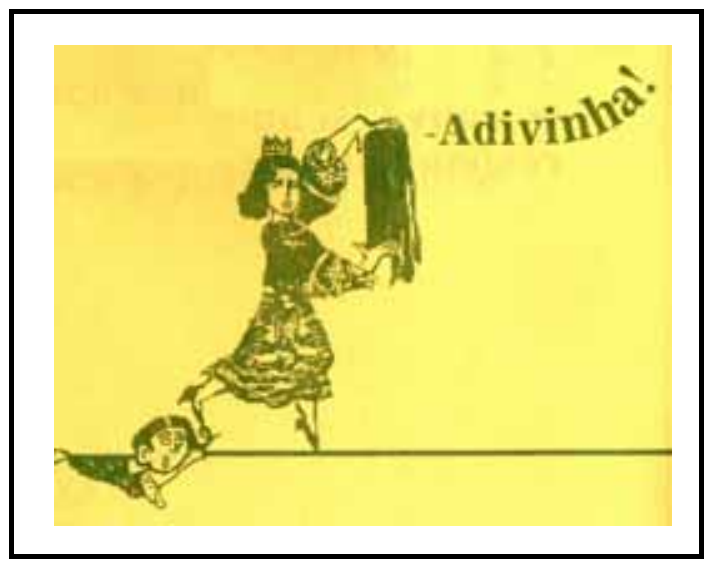

posicionada na parte inferior da página, segurando, em atitude solene, o quadro pintado de preto. A reta que demarca a moldura, sugere o traçado de uma corda que sustenta figuras - moças posicionadas vertical e horizontalmente - ovacionando a princesa.

\footnotetext{
${ }^{48}$ GOFF, Jacques Le. O Imaginário Medieval. Trad. Manuel Ruas. 3.ed. Portugal, Estampa, 1994, p.208.

${ }^{49}$ PALO, Maria José; OLIVEIRA, Maria Rosa D. Literatura Infantil. Voz de criança. Série Princípios. São
} 
Essa ilustração, em sentido horizontal, dá idéia da seqüência da cena, quando, o traçado do cabelo de uma delas alonga-se para formar o bico do sapato da princesa, formalizada na representação do traço da ilustradora.

Detalhes tais como o traçado do sol; em um canto da página; a lua no outro extremo; pássaros e personagens espectadores, são elementos que figuram no programa narrativo.

O texto verbal, ocupando a parte superior da página, devidamente nivelado, permite que o esboço que insinua a princesa adquira movimento, dada a posição dos pés.

Os espaços em branco, deixados no final das páginas, objetivam acomodar o olhar do leitor no foco de maior atenção e suavizar-lhe o desconforto trazido pela estrutura cromática - gradações da tonalidade azul, delimitando o jogo de luz e sombra.

No quadro inicial da ilustração, exemplificado através da prancha número 8, percebe-se, à esquerda, a introdução dos plebeus, verticalmente posicionados, uns sobre os outros, como se estivessem atuando no meio de um picadeiro. No topo, portando uma pequena rede de caçar insetos, está um representante do povo. Note-se que o traçado das personagens excede às fronteiras do real quando se apóia na configuração de uma nuvem, sob a presença do sol. Do lado oposto, e entre as estrelas, apresenta-se a realeza, que conta com a proteção da lua. Um soldado do Reino, servindo-se também da mesma rede de caça, sustenta-se no ápice da seqüência de personagens. 


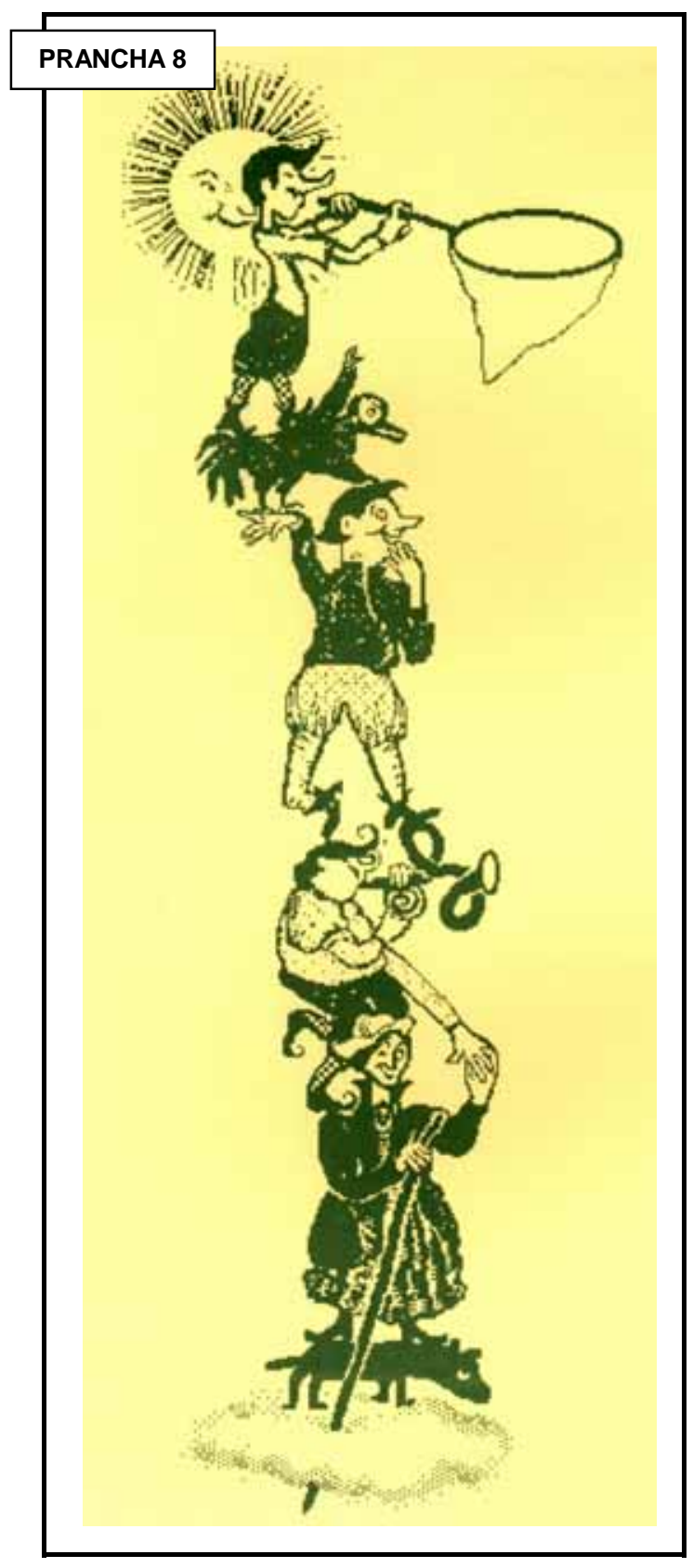

A folha de papel de seda, utilizada no início e final do livro responde pelo efeito de movimentação das personagens em cena. A interação de movimentos entre as páginas e a folha de seda, no abrir e fechar do livro, dota as personagens, segundo o olhar do leitor, de dinamicidade, aspecto que poderia insinuar a produção de imagem animada em filme de $8 \mathrm{~mm}$, de velocidade reduzida, tal qual o impulso de movimento do leitor, no manuseio do livro.

Em outra interpretação, a folha de seda poderia, ainda, atuar como um demarcador social, uma linha divisória entre a Corte e o Povo, entre a riqueza 
e a pobreza, o simples e o altamente sofisticado.

Em tonalidade azul acinzentada, configura-se o pequeno inseto popularmente denominado Louva-a-deus ${ }^{50}$ que ganha espaço na folha de seda, e passa a mover-se, recepcionando o leitor, logo no início da obra. A relação estabelecida entre Louva-a-deus e as duas classes sociais, estender-se-á a Louva-adeus homem, aquele “... que andava sempre com um livro de orações ...”51 A conotação referente ao inseto, completa-se em outro referencial - homem bom, despretencioso, dado ao hábito da oração. Em destaque, na folha de seda, Louvaa-deus homem ganha vida, apoiado em um balanço, que se desloca de um lado a outro da página.

As rupturas de linha igualmente invocam a presença do teatro. Ainda no quadro acima citado, prestigia-se todos os elementos da composição. O foco não se restringe somente às tomadas de cena, mas permite uma visualização simultânea e ampliada das ações paralelas. Os expectadores, posicionados sobre a moldura observam, no canto inferior direito da página, o delinear de uma mão que traz, sorrateiramente, dos bastidores, uma corda em forma de forca e a deposita sobre o vocábulo "forca”, deixando transparecer o cuidado com os detalhes finais de produção durante o espetáculo, conforme se verifica na prancha número 9.

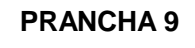

\footnotetext{
${ }^{50}$ É interessante a alcunha ter sido gerada pelo hábito de andar com um livro de orações. Na obra, fato bastante significativo para sugerir religiosidade, ou ainda, indiretamente, que a sorte de Louva-a-deus, poderia ser antes Graça alcançada pelas freqüentes orações.

${ }^{51}$ LAGO, Angela. Sua Alteza A Divinha. p.4.
} 
Tudo nos faz crer que a princesa é a contra-regra que prepara antecipadamente o palco para a ação. Salienta-se aqui o confronto sugerido entre a atuação que a princesa e Louva-a-deus terão “no palco” logo mais, na seqüência narrativa. Ela detém o controle interno da situação, já providenciou os materiais e instrumentos que usará no desafio. No palco, pode-se dizer, que ela atua seguindo as falas do “script”, já tendo ensaiado. Louva-a-deus contará com sua capacidade de improvisar e de adaptar-se a situações inusitadas.

Os cortes freqüentes das cenas, na virada da página, provocam tensão. O ato de virar a página corresponde, segundo Angela Lago, aos momentos de suspense, às pausas utilizadas no contar de uma estória. O leitor, então, sentese seduzido a continuar a leitura. Angela Lago ${ }^{52}$ justifica o emprego da quebra de página, comparando a construção de um livro a de uma cidade: “... arquitetar um livro é arquitetar uma cidade e virar a página é como dobrar uma esquina, na expectativa de uma nova descoberta.” Os cortes ainda respondem pelo andamento da ação, visam agilizar o final da narrativa e com ela efetivar o riso que o desfecho proporciona.

PRANCHA 10

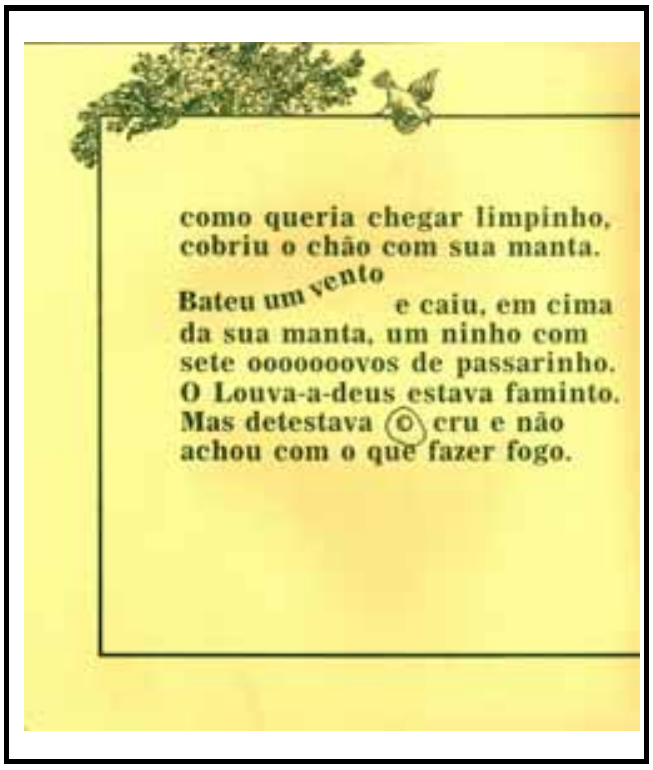

A prancha número 10 evidencia que a moldura, de contornos irre-

${ }^{52}$ LAGO,Angela. Seminário: “Literatura Arte Educação. Intencionalidades da Ilustração”. São Paulo, 1990. 
gulares, sofre freqüentes rupturas de linha e cede lugar a esboços de pássaros, insetos e pequenos arbustos que margeiam a narrativa. A cena que ilustra a entrada de Louva-a-deus no palácio consolida a afirmação. As retas que compõem a moldura alargam-se, na diagonal, para constituir parte da sala de entrada e transformá-la em palco. As curvas delineiam o traçado da porta. A extensão da sala do palácio, sugerida pelo desenho, torna a configuração de Louva-a-deus muito pequena perante a suntuosidade do castelo. A personagem, posicionada no lado inferior esquerdo da página, como se vê nas pranchas números 11 e 12, contrapõese à princesa disposta na parte superior da página seguinte. A cena evidencia uma antítese social que, através da performance de Louva-a-deus, vai sendo, aos poucos, minimizada.
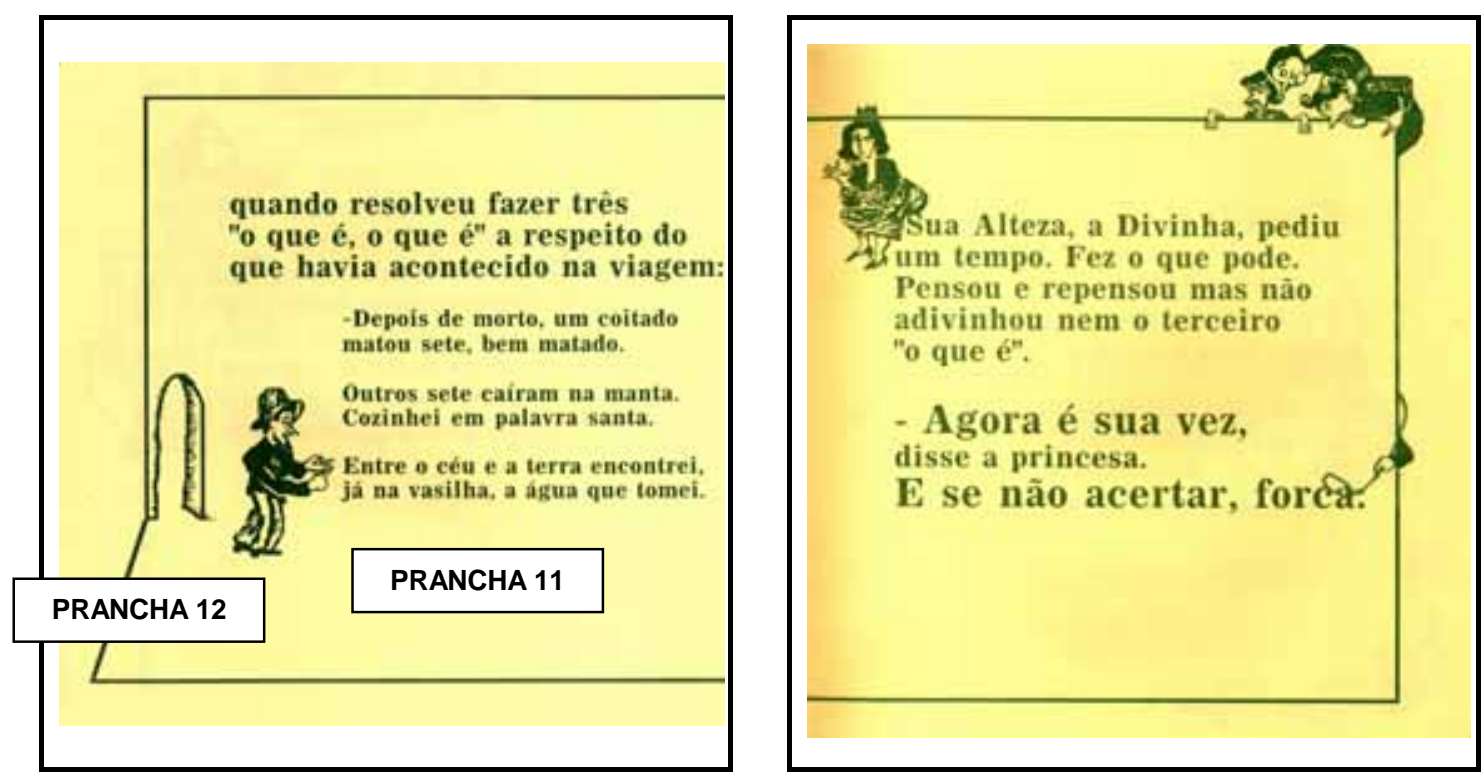

Em outro quadro, nas margens que delimitam a narrativa, conforme demonstra a prancha número 13, presenciamos a participação do público, ansioso, assim como também o leitor, pelo início do confronto entre A Divinha e Louva-a-deus. Atenta ao resultado, a platéia, por meio de habilidades malabarísticas, revela feições expressivas, em termos de aprovação, em favor de Louva-a-deus, sem contudo, tomar lugar efetivo na trama. O código verbal elucida: “A esta altura, a corte estava torcendo para o Louva-a-deus adivinhar. Ele nervoso, bateu a 
mão na testa e desabafou...”53

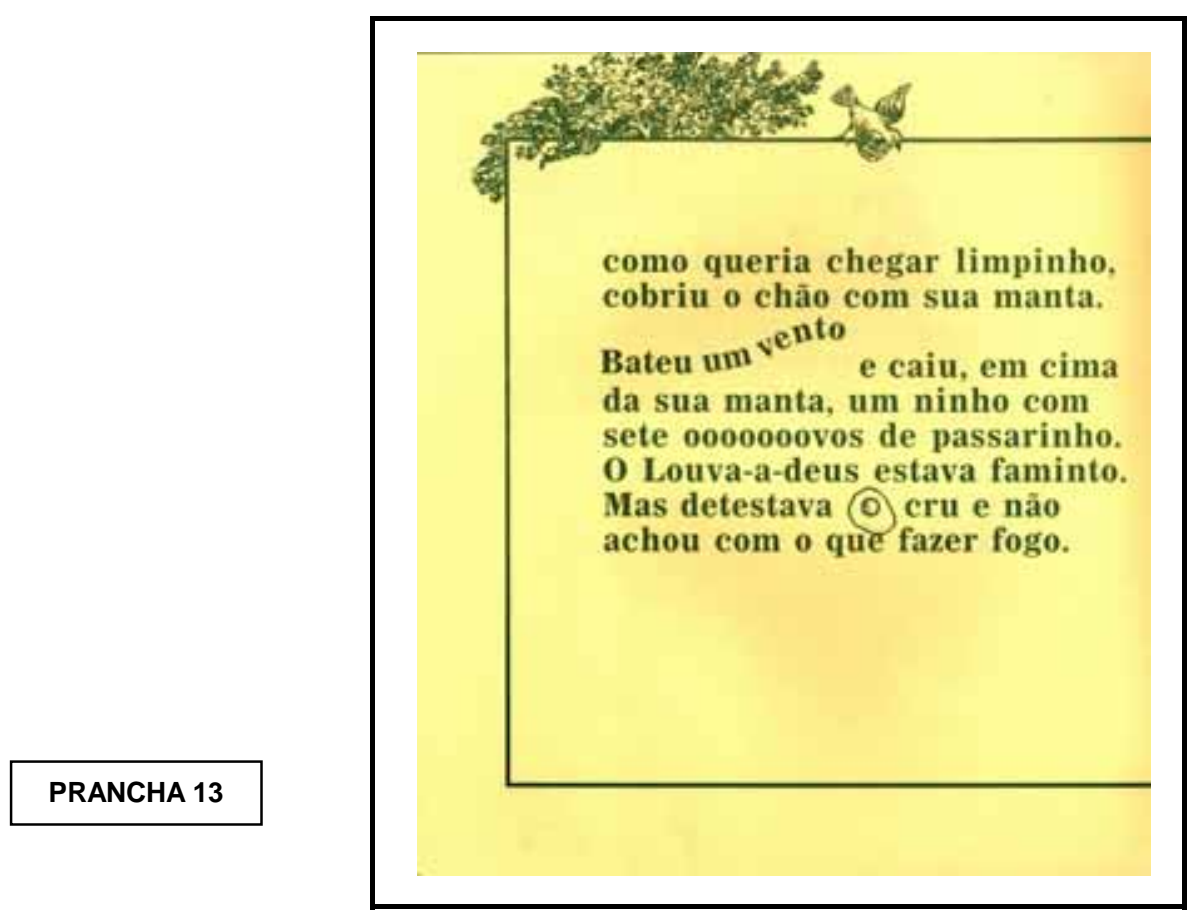

A elaboração dos desenhos não persegue um único plano. As cenas que demonstram a trajetória de Louva-a-deus até o seu destino, apresentam-se em ângulos diferentes e assemelham-se às tomadas cinematográficas, ora filmadas no plano geral, ora no plano médio, quando se deseja focar os momentos de maior importância da cena, dentro do tempo narrativo. Note-se que o percurso traçado pela personagem é paralelamente acentuado pela presença do vento que inclina a linha do texto, que assume as dimensões de uma montanha, ou acentua graficamente a entrada do castelo. Louva-a-deus, ao trazer consigo o cenário natural mesclado ao cenário da praça, vamos assim nomear, estará mesclando esses elementos ao cenário do castelo. Nessa seqüência, pode-se visualizar a transformação ocorrida. O cenário tradicional e rígido do castelo transforma-se em palco, capaz de exibir um espetáculo para quem já está e ou faz parte do castelo, pelas mãos da princesa, enquanto esta se prepara para receber o desafiante. Já se observa uma abertura nesse movimento de sala para palco, que atinge proporções maiores, com a chegada de Louva-a-deus. O palco transforma-se numa praça, o

\footnotetext{
${ }^{53}$ LAGO, Angela. Sua Alteza A Divinha. p.21.
} 
povo, agora, participará do espetáculo. Apresentados os atores, o cenário, as adivinhas poderão ser declinadas.

\subsection{Formas manifestas do riso}

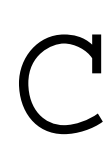

oncluindo, a obra possui um certo nível de comicidade que não se restringe ao desfecho, mas abrange outros segmentos da narrativa.

Capa e contra capa demonstradas através das pranchas números 14 e 15, asseguram uma imagem de aparência circular, composta também de personagens sobrepostas. Os dois coqueiros paralelos, que servem de base ao suposto círculo, permite-lhe pequena abertura. O efeito criado pela perspectiva flagra o esboço da princesa, que sustenta o corpo nos cotovelos, os quais, por sua vez, mantêm-se sobre a letra “u” do vocábulo “sua” e apóia os dois pés sobre a cabeça de dois representantes - um da Corte e outro da Plebe, um cavalheiro nobre e Louva-a-deus, respectivamente, representando o eixo de uma construção circunscrita. Esta disposição circular do desenho demonstrando uma prática, aparentemente inusitada, comprova a expressão marota da princesa.
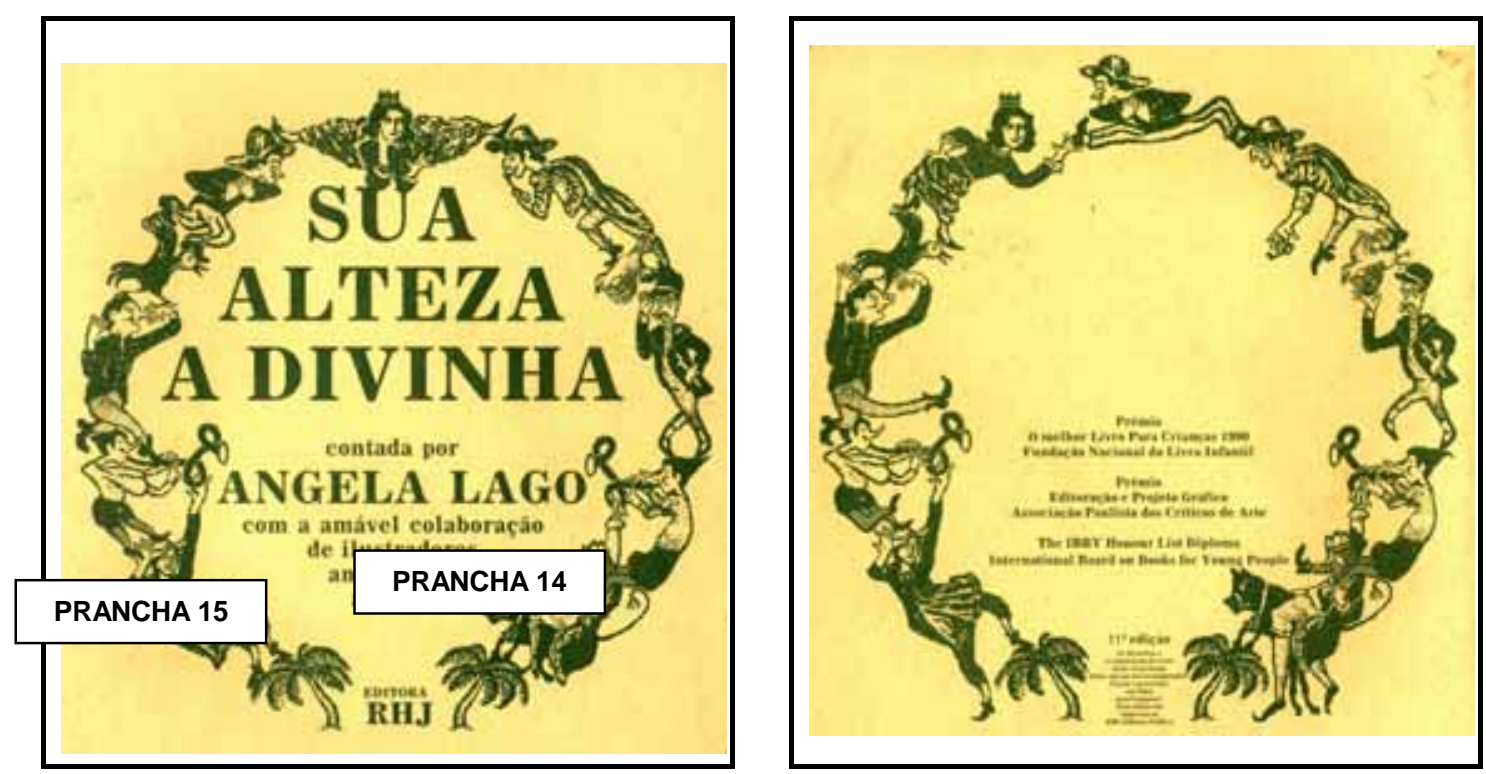

O efeito do riso provocado por este segmento ilustrativo deve-se, não somente ao 
fato dos desenhos assemelharem-se, segundo Bergson, à imagem do homem, “não há cómico fora daquilo que é propriamente humano.” ${ }^{4}$, mas por tornar evidente a supremacia que o trono oferece.

A cena presente na capa aparece espelhada na contra capa. Observese, que através desse recurso e da circularidade em que as personagens estão dispostas, confirma-se a inversão de valores, ocorrida no desfecho narrativo. É preciso que se verifiquem as diferenças entre a posição inicial e final das personagens, examinando-se a capa e a contra capa separadamente, e depois espelhar uma à outra. Na contra capa se percebe que as personagens mudaram de lugar. $\mathrm{O}$ conteúdo diagramático mostra a princesa sobre o nobre, comprimindo-a com os pés; evidencia a mão de A Divinha segurando um dos pés de Louva-a-deus, que figura no topo do que se sugere uma escala humana. A mudança de lugar nessa escala pode ser vista como o reconhecimento que Louva-a-deus recebeu após a vitória e o casamento.

A posição dominadora da princesa que sustenta o pé de Louva-adeus pode ser assim interpretada: ao casar-se com Louva-a-deus, a princesa reconhece o poder de quem a venceu, do marido, que está no círculo das personagens, acima dela. No entanto, o pé do marido sustenta-se em sua mão, ou seja, ela foi vencida no desafio, casou-se com o vencedor, mas não abdicou do poder que tinha anteriormente. Louva-a-deus tornou-se seu marido, aparece no topo da escala, mas não há razão para se supor que ele tenha sido premiado com o reino.

Sob outra perspectiva, a princesa - bastante inteligente - como soberana, conhece a importância da participação, do apoio, “da aliança” com o povo para a manutenção do poder. Nesse caso, Louva-a-deus aparece em destaque, mas ainda está com o pé na mão da princesa.

Outros quadros ilustrativos, revelam a postura da princesa, ora sentando-se, ora deitando-se sobre as palavras. A título de exemplificação, citamos

\footnotetext{
${ }^{54}$ BERGSON, Henri. O Riso Ensaio sobre a Significação do Cómico. Trad. Miguel S. Pereira. Lisboa, Relógio
} 
na prancha número 16, a descrição dos passos acelerados da princesa em direção a Louva-a-deus, no momento da declinação das adivinhas - mãos artisticamente posicionadas, o salto do sapato em evidência (quase pisando o vocábulo "moço" - desejo disfarçado de espezinhar o adversário) e os dedos cruzados, ocultos pelas costas - gestos sugeridos pelo automatismo que levam à comicidade.

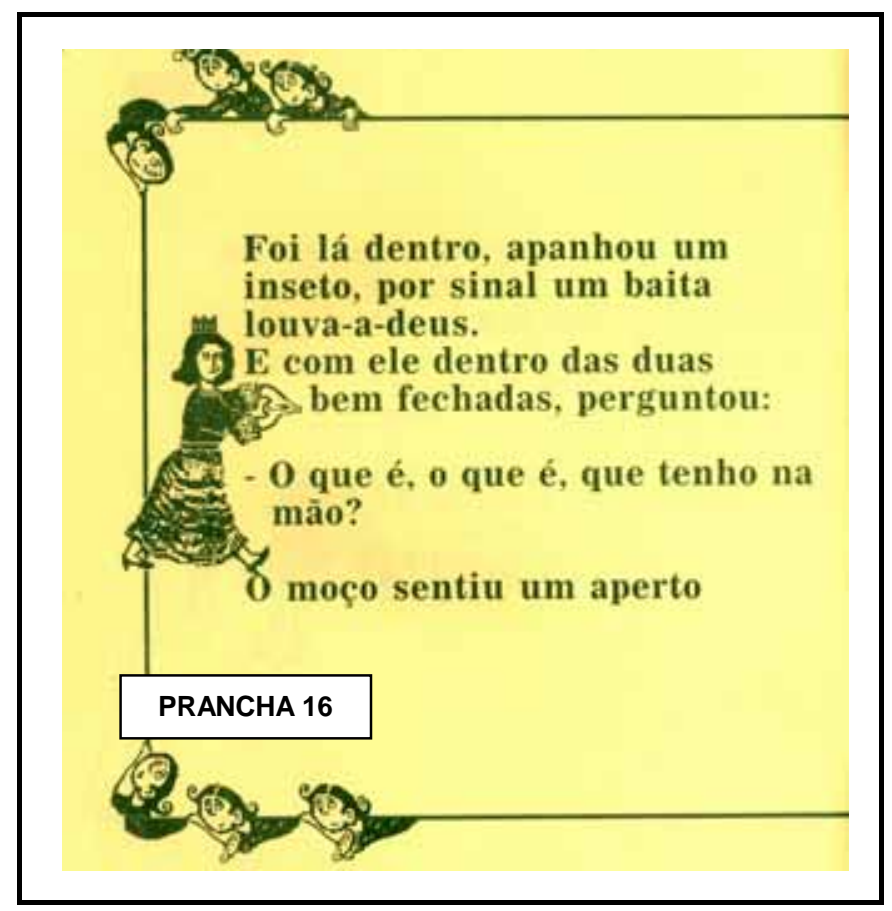

No texto verbal, o cômico, neste mesmo quadro, nasce quando o narrador, ironicamente introduz, pela linguagem informal, uma expressão que retrata a contrariedade de A Divinha num momento de desvantagem perante Louva-a-deus. "A princesa levou um susto danado e perguntou como é que ele tinha conseguido acertar. O Louva, sendo sincero, respondeu que não tinha sido difícil. - Ainda por cima quer me fazer de besta! disse a Divinha." 55

A representação pictórica de Louva-a-deus, de modo geral, conduz ao riso através da vestimenta, um tanto desproporcional ao manequim, aos sapatos de bico fino e ao uso do chapéu de abas disformes.

O efeito cômico incide igualmente na exteriorização dos movimen- 
tos da personagem. Costas inclinadas para frente, braços caídos, passadas largas e o livro de orações em uma das mãos lembram uma certa "rigidez de mecanismo onde seriam de se esperar a agilidade atenta e a flexibilidade ...”56 As circunstâncias da narrativa levam à comicidade porque a personagem, que age de modo natural, não tem consciência da falta de elasticidade e sociabilidade, manifestadas em seu comportamento, mas a Corte, que representa a sociedade apercebe-se dessa deficiência. A repressão pela falta será o riso, pois a personagem foge aos padrões estabelecidos pela comunidade, ela “... tende a afastar-se do centro comum em torno do qual a sociedade gravita ...”57. Porém o público, de acordo com a obra, que pune com o riso insensível, é o mesmo que apóia a personagem a superar o medo e a enfrentar a princesa.

No ápice do espetáculo, quando é exigida de Louva-a-deus a habilidade de contador de estórias, os seus gestos são maquinais: mãos sobre os olhos evitando a platéia, ora os pés voltados para dentro dos joelhos, ora as pernas entrelaçadas, mão no peito expressando angústia, movimentos que por si sós levam ao riso.

Contudo, os movimentos maquinais da personagem, desde o início da viagem até a chegada ao castelo, ganham dimensão quando, segundo Bergson $^{58}$, “... podemos ligar os seus caracteres a uma causa profunda, a de uma certa 'distracção fundamental' da pessoa, como se a alma se tivesse deixado de fascinar, hipnotizar, pela materialidade de uma ação simples.”

O fator “distração” será, de acordo com a seqüência de fatos, uma das características da personagem, entendido como um defeito de personalidade. Envolvido com a viagem, Louva-a-deus não se preocupou com a seleção das três adivinhas que deveria propor à princesa. Ele adentrava ao castelo “...quando resolveu fazer três "o que é, o que é” a respeito do que havia acontecido na

\footnotetext{
${ }^{56}$ LAGO, Angela. Sua Alteza A Divinha. p. 18

${ }^{57}$ BERGSON, Henri. O Riso. Ensaio sobre a Significação do Cómico. p.23.

${ }^{58}$ Idem, ibidem, p.26.
} 
viagem ..."59

A distração, vista na obra como o momento de deslocamento, de evasão da personagem do mundo real, é assinalada por suas atitudes no ato do questionamento. De acordo com a prancha número 17, o corpo contorcido da personagem expressa seu estado de impaciência, aspecto que o aproxima do povo que o reconhece como o herói, que também é humano e vacila num momento de decisão.

PRANCHA 17

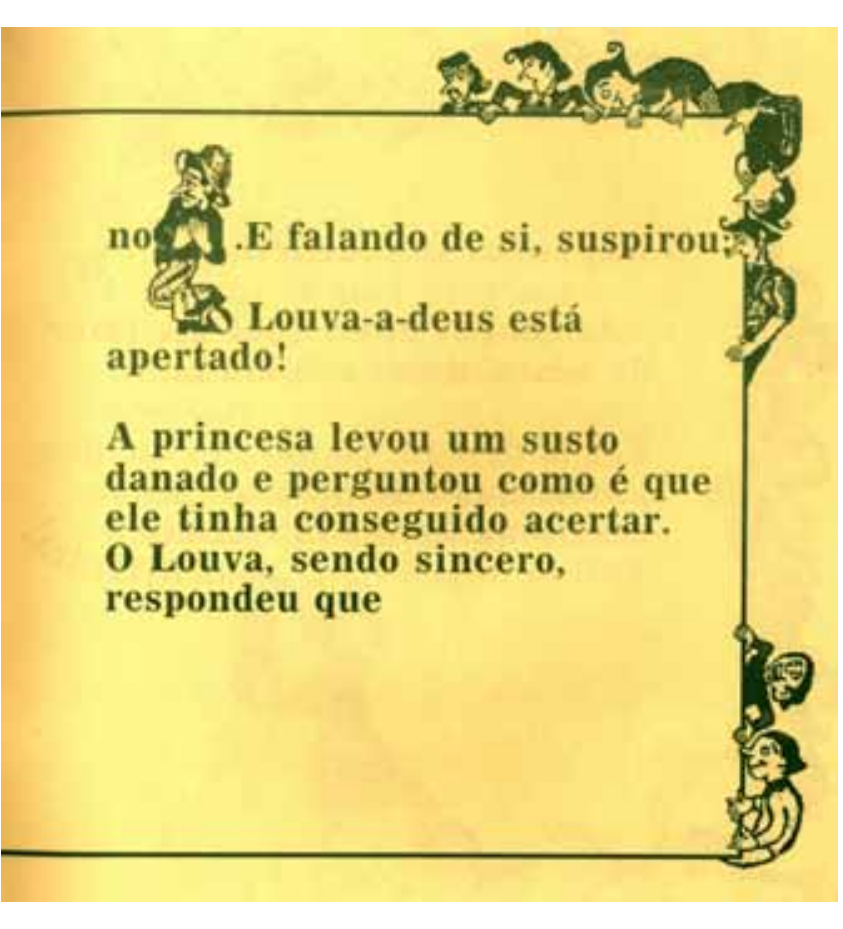

Mas o desespero, que é demonstrado através do texto em sentenças como: "Louva-a-deus está apertado”,60 “o quadro está preto”61, pronunciadas distraidamente, como forma de exteriorização de sentimentos, parece ser o componente negativo de maior realce na personalidade de Louva-a-deus. Instaura-se então, uma ocorrência singular: a desatenção da personagem, que poderia ser classificada de antagônica, e que desencadeia o riso na platéia, vai isentá-la, em outra vertente, de uma situação limite, uma vez que o seu “desabafo” vai coincidir com as respostas

\footnotetext{
${ }^{59}$ LAGO, Angela. Sua Alteza A Divinha. p.14.

${ }^{60}$ Idem, ibidem, p.17.

${ }^{61}$ LAGO, Angela, op. cit., p.19.
} 
esperadas pela princesa. A platéia, entusiasmada pela espontaneidade nas atitudes de Louva-a-deus, passa, então, do riso à ovação. Assim, o herói livra-se da condição de embaraço e naturalmente aceita a aclamação popular, sem “mágoas”, nem "ironia."

\subsection{A improvisação como recurso: de tolo a herói}

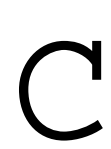

onfirmamos, também que, sob um outro ângulo de visão, a atitude de Louva-a-deus, perante o impasse, poderia revelar versatilidade da personagem quanto à prática da improvisação, considerando ser essa uma característica comum do indivíduo medievo, aspecto resgatado pela obra. Devido às experiências vividas na floresta e ou mesmo à sua irreverência, a personagem não dá a devida atenção à elaboração das adivinhas, as quais poderiam tê-lo conduzido a recorrer, no momento adequado, a uma encenação e, assim, ter conquistado a vitória.

No perfil da personagem são nítidos os traços de menino imaturo, alegre, adaptado ao ambiente descontraído das ruas. Ele simboliza o indivíduo familiarizado com a camada da população com quem convive na praça pública, que interage com as feiras e festas populares, que partilha da intimidade do povo, quando “... o seu corpo está em contato com os das pessoas de todas as idades e condições; ele se sente membro de um povo em estado perpétuo de crescimento e renovação.”62 Segundo Bakhtin, na Idade Média, “a praça pública era o ponto de convergência de tudo que não era oficial, de certa forma gozava de um direito de 'exterritorialidade' no mundo da ordem e da ideologia oficiais, e o povo aí tinha sempre a última palavra.”’3

A estória está centralizada, como vimos na personagem-herói Louva-a-deus, personagem aparentemente tola. Seu bom desempenho é acidental, as

\footnotetext{
${ }^{62}$ BAKHTIN, Mikhail. Cultura Popular na Idade Média e no Renascimento. p.79.
} 
respostas às adivinhações coincidem com o estado de espírito da personagem no momento do desafio e representam traços da linguagem oral.

A figura do bobo, do pícaro significa o ser totalmente "idiota", “tolo”, a representação da inocência. O seu comportamento o faz ser visto como um lunático (do latim “lunaticu”) ${ }^{64}$, aquele que está sob a influência da lua, ungido pela lua, portanto protegido.

O tolo, por ser considerado puro, é eleito pela sociedade como o elo existente entre o humano e o divino. Adjetivado seguidamente de louco, o bobo tudo percebe, mas o homem não lhe dá ouvidos, pois embora ele tenha a percepção para detectar o erro, ele não possui o poder de verbalizar, sem poder, portanto, para reverter uma situação, em princípio. Louva-a-deus pode ser caracterizado, de acordo com a obra, como o bobo que se aventura e arrisca a própria vida. Assumindo traços comportamentais do tolo, ele age livremente e revela, na performance realizada no palácio, traços de seu comportamento irreverente, rompendo com os padrões de ordem social, embora conhecendo os riscos de punição.

Podemos, ainda, associar a sua figura, aos elementos do povo que se dispunham em praça pública, nas denominadas “festas dos loucos”,65, realizadas durante o período medieval. No sentido figurado, celebravam e contestavam, os dogmas da Igreja, servindo-se, para isso, de um repertório chulo. Argumenta Bakhtin que as figuras representativas do bobo, do trapaceiro e do bufão possuem

“... uma ligação muito importante com os palcos teatrais e com os espetáculos de máscaras ao ar livre, elas se relacionam com um certo setor particular, mas muito

\footnotetext{
${ }^{63}$ Idem, ibidem. p.132.

${ }^{64}$ FERREIRA, Aurélio B. Holanda. Novo Dicionário Aurélio da Língua Portuguesa. 2.ed. rev. Rio de Janeiro, Nova Fronteira, 1986, p.1053.

${ }^{65}$ Sobre manifestações públicas na Idade Média, consultar BAKHTIN, Mikhail em Cultura Popular na Idade Média e no Renascimento.
} 
importante para a vida na praça pública.” 66

A narrativa, perseguindo as trilhas do imaginário medieval, insinua a crença insistente na maldade natural à mulher e sua predileção à feitiçaria, temida como agente de Satanás, quando aponta em sua personagem feminina uma oscilação comportamental capaz de promover, no entanto, mais de uma interpretação.

A princesa defende uma postura rígida. Adjetivá-la de má, porque impõe a morte como castigo, seria precipitação. O jogo é proposto, os participantes têm conhecimento das regras e aceitam o desafio. O comportamento descortês de A Divinha, durante o combate, acentua-se no momento em que ela se sente derrotada, mas isso também faz parte do plano. Louva-a-deus é flexível no tocante à aceitação natural das coisas, “... por ser simples e sem sofisticação, tem uma atitude simples e sem pretensões diante da vida."67 Ainda que a personagem expresse medo de uma possível punição, seu caráter descontraído consegue operar mudanças na conduta da princesa que, como o leitor, vai acompanhando o modo como Louva-a-deus conquista o apoio dos que assistem ao desafio e passam a torcer por ele. A princesa bastante sagaz como se apresenta durante todo o tempo deve reconhecer o caráter paradoxal que está vivendo. Como futura noiva demonstra entusiasmo, chega a torcer em determinado momento pela vitória de Louva, aparenta estar satisfeita por ter encontrado um noivo à altura de suas adivinhas, de decifrar o proposto, ou seja, à altura dela. Aceitar Louva-a-deus, que representa o povo, significa reconhecer elementos oriundos de diferentes camadas culturais, cujo entrelaçamento, a princesa supõe ser um elemento importante para a conservação do poder. Por outro lado, como princesa, poderia sentir-se ameaçada e infeliz, percebendo sua iminente derrota por um plebeu. No entanto, não é o que se verifica. A princesa parece reconhecer e apreciar o poder popular.

\footnotetext{
${ }^{66}$ BAKHTIN, Mikhail. Questões de Literatura e de Estética. p.275.

${ }^{67}$ FRANZ, Marie Louise Von. A Interpretação dos Contos de Fada. Trad. Maria Elci S. Barbosa. São Paulo, Paulinas, 1990, p.81.
} 
Consolidamos essa afirmativa através da prancha número 18.

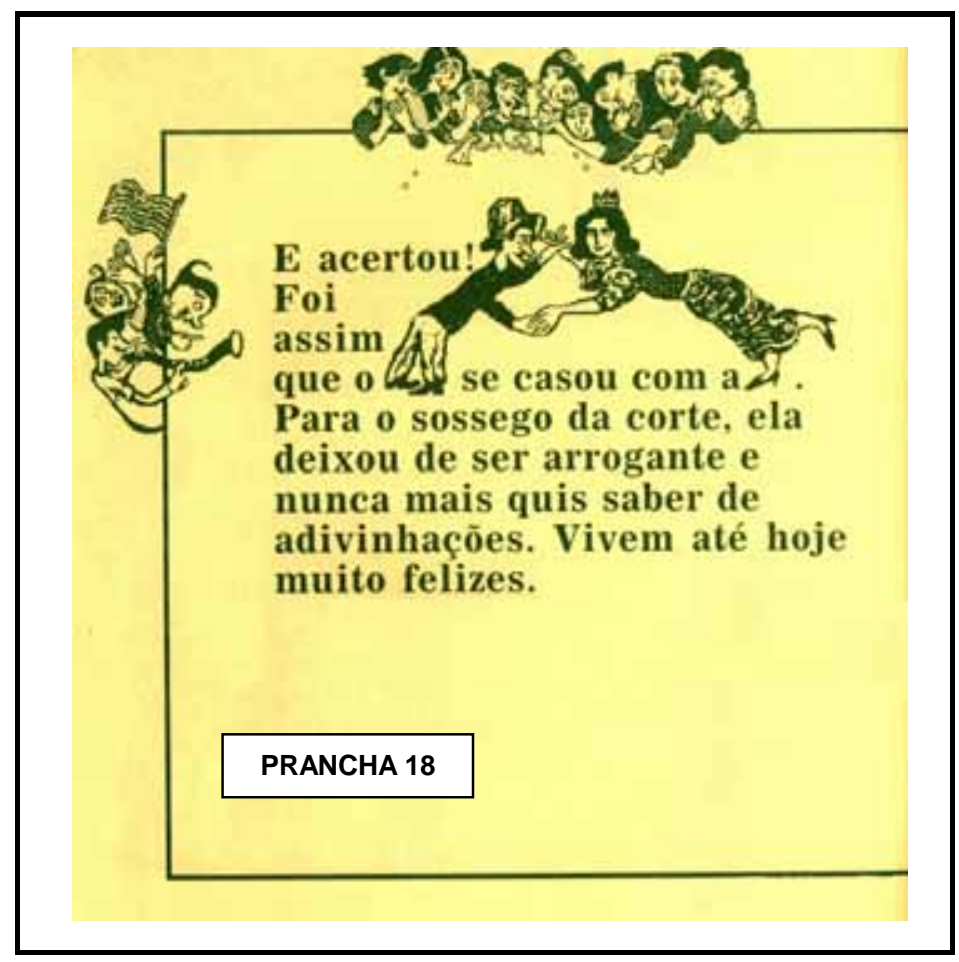

O sucesso de Louva-a-deus, representa para ambos, a renovação, o fim de um ciclo e o início de uma nova era. A efabulação expressa a intenção do plebeu em vencer os obstáculos e equiparar-se ao nível social da princesa; mas a luta é bipolar, pois também exalta os direitos e sentimentos do elemento feminino. O desejo de realização de A Divinha, visando à perpetuação do trono, sobrepõe-se à passividade daquela que aguarda confortavelmente ser resgatada pelo seu príncipe. A fusão entre o imaginário - o sonho de ter o príncipe e, o mundo real, expresso pelas lutas e paixões que o homem precisa enfrentar, é que lhe vão conferir a vitória plena, a sua auto realização como mulher. De outro modo, o conflito de natureza existencial abordado no texto, vai oscilar entre o amor e a sabedoria trazida pela palavra, fator que , de acordo com o conto, traz a preservação ou a destruição da vida.

\subsection{Pelos veios da cultura medieval}


s estudos sobre a tradição oral têm demonstrado como as variadas ramificações de certas narrativas, oriundas, segundo alguns pesquisadores, de um mesmo centro comum, têm sobrevivido graças à expressão popular e à literatura, que, desde há muito, tem resgatado as raízes culturais, os mitos, ritos, o sabor do conto popular e disponibilizado em forma de recriação ao leitor dos tempos modernos.

Muitas são as recriações de narrativas construídas à base de pergunta e resposta, quando o inquiridor é “... um ser mais ou menos cruel, ou uma princesa ou um rei, enfeitiçados e ligados a poderes maléficos.”, ${ }^{\text {,8 }}$ Para Jolles, “... a fórmula é sempre a mesma: 'Adivinha ou morre!' Em todos os casos, trata-se de uma prova capital, na acepção profunda do termo."69 A título de exemplificação, transcrevemos abaixo variantes da estória da princesa que propunha adivinhas aos seus pretendentes, recolhidas por L. C. Cascudo, Teófilo Braga, Adolfo Coelho e Sílvio Romero, (fontes portuguesas e brasileiras) oportunidade em que destacaremos os elementos relevantes entre estas variantes e Sua Alteza A Divinha.

\begin{abstract}
A Adivinha do Amarelo $^{70}$
“ Um rei tinha um filha tão inteligente que decifrava imediatamente todos os problemas que lhe davam. Ficou, com essa habilidade, muito orgulhosa e disse que casaria com o homem que the desse uma adivinhação que ela não descobrisse a explicação dentro de três dias. Vieram rapazes de toda parte e nenhum conseguiu vencer a princesa que mandou matar os candidatos vencidos. Bem longe da cidade morava uma viúva com um filho amarelo e doente, parecendo mesmo amalu-
\end{abstract}

\footnotetext{
${ }^{68}$ JOLLES, André. Formas Simples. p.113.

${ }^{69}$ JOLLES, André. loc. cit.

${ }^{70}$ CASCUDO, Luis da Camara. Literatura Oral no Brasil. 3.ed. Belo Horizonte. Itatiaia, 1984, p.321-23 passim.
} 
cado. O Amarelo teimou em vir ao palácio do rei apresentar uma adivinha à princesa, apesar de rogos de sua mãe que o via degolado como sucedera a tantos outros. Saiu ele de casa trazendo em sua companhia uma cachorrinha chamada Pita e um bolo de carne, envenenado, que lhe dera sua própria mãe. Andou, andou, andou, até que desconfiando do bolo o deu à Pita. Esta morreu logo. O Amarelo, muito triste, jogou a cachorrinha no meio do campo e os urubus desceram para comê-la. Sete urubus morreram também. O Amarelo, com fome, atirou com uma pedra a uma rolinha mas errou e matou uma 'asa branca'. Apanhou-a e sem deixar de andar ia pensando como podia comer sua caça quando avistou uma casinha. Era uma capela abandonada há muitos anos e caindo de velha. O Amarelo entrou e aproveitando a madeira do altar fez uma fogueira e assou o pássaro, almoçando muito bem. Ao sair, viu que descia na água do rio um burro morto, coberto de urubus. Estando com sede, encontrou um pé de gravatá, com água nas folhas e bebeu a fartar. Quase ao chegar à cidade reparou em um jumento que escavava o chão com insistência. O Amarelo foi cavar também e descobriu uma panela cheia de moedas de ouro. Chegando à cidade, procurou o palácio do rei e disse que tinha uma adivinhação para a princesa. Marcaram o dia e o Amarelo, diante de todos, disse:

'Saí de casa com massa e Pita.

A Pita matou a massa e a massa matou a Pita

Que também a sete matou.

Atirei no que vi.

Fui matar o que não vi.

Foi com madeira santa

Que cozinhei e comi.

Um morto vivos levava.

Bebi água, não do céu. 
O que não sabia a gente

Sabia um simples jumento.

Decifre para seu tormento.'

A princesa pediu os três dias para decifrar e o Amarelo ficou residindo no palácio, muito bem tratado. Pela noite, a princesa mandou uma sua criada, bem bonita, tentar o Amarelo para que lhe dissesse como era a adivinhação. O Amarelo compreendeu tudo e foi dizendo: - Só direi se você me der a sua camisa. Vai a moça e deu a camisa ao Amarelo que contou muita historia mas não explicou a adivinhação. A princesa, vendo que a criada nada conseguira, mandou a segunda e houve a mesma cousa, ficando o Amarelo com outra camisa. Na última noite a princesa procurou o Amarelo para saber o segredo. O rapaz pediu a camisa e a princesa não teve outro remédio senão a entregar. No outro dia, diante da Corte, a princesa explicou a adivinhação: - Massa era o bolo que a cachorra Pita matou porque comeu e foi morta pelo bolo, matando envenenados os sete urubus. A rolinha escapara da pedrada mas a asa-branca morrera sem que o caçador a tivesse visto. Assou-a com madeira que guardara a Hóstia Santa. Um cadáver de burro levava, rio abaixo, uma nuvem de urubus vivos. A água que se conserva entre as folhas do gravatá, matara a sede do Amarelo. O que não sabia o povo inteligente, sabia um jumento que cavava ouro enterrado ao pé de uma árvore.

Era tudo. Bateram muita palma mas o Amarelo disse logo: O fim dessa adivinha é fácil e eu vou dizer logo antes que morra degolado!

'Quando neste palácio entrei

Três rolinhas encontrei;

Três peninhas lhes tirei 


\section{E agora mostrarei !..’}

E foi puxando a camisa da primeira criada e mostrando. Fez o mesmo com a da segunda. Quando tirou a camisa da princesa, esta correu para ele, dizendo: - Não precisa mostrar a terceira pena! Eu disse a adivinhação porque você me ensinou, e me ensinou porque é meu noivo...

Casaram e foram muito felizes. ${ }^{71}$

\section{A Princesa Adivinhona ${ }^{72}$}

“Era uma vez um rei que tinha uma filha muito inteligente e perspicaz. Quando se pôs moça não havia problema que ela não decifrasse nem pergunta que ficasse sem resposta. O rei ficou muito orgulhoso da prenda da princesa que disse dar a mão em casamento a quem desse uma adivinhação e ela não destrinchasse em três dias. Muita gente correu para ganhar a mão da princesa mas ela explicou todas as charadas e os candidatos apanhavam uma surra, voltando envergonhados. Os tempos foram se passando e ninguém aparecia para vencer a princesa.

Muito longe da cidade vivia uma velha com um filho muito amarelo mas sabido como ele só. O rapaz entendeu de tentar a sorte e não houve conselho que o arredasse desse desejo. Agarrou uma espingarda e tocou-se para a cidade.

Depois de muito caminhar, sentindo fome, procurou caçar e avistou um veado comendo. Foi devagar e largou-lhe um tiro que o matou. Indo esfolar verificou que era uma veada, com uma veadinha no ventre. Tirou o couro e seguiu viagem. Adiante encontrou os carpinteiros tralhando numa Igreja e colocaram um altar muito velho do lado de fora. O rapaz carregou umas tábuas desse altar. Adiante parou, fez uma fo-

\footnotetext{
${ }^{71} \mathrm{O}$ autor não especifica o local da recolha deste conto.
}

${ }^{72}$ CASCUDO, L. Camara. Contos Tradicionais do Brasil. Belo Horizonte, Itatiaia, 1986, p.290-91. 
gueira com os paus do altar, assou a veadinha e comeu. Estava comendo quando viu que um jumento morto ia descendo pelas águas do rio, com muitos urubus trepados em cima. Bebeu água que estava entre as folhas das macambiras. Logo que chegou à cidade procurou o palácio do rei e disse que queria apresentar um problema. No dia marcado a princesa veio para o salão, com muito povo, e o rapaz amarelo sentou-se em cima do couro da veada e disse:

'Atirei no que vi

Fui matar o que não vi.

Foi com madeira santa

Que cozinhei e comi.

Bebi água não do céu...

Um morto vivos levava.

O que me serve de assento, Acerte, para seu tormento.'

A princesa pensou, pensou, matutou, matutou e pediu três dias para estudar. Vendo que não arranjava nada mandou uma criada fazer-se de namorada do Amarelo e saber o segredo. O Amarelo conversou e pediu que a moça lhe desse a camisa que ele dizia o segredo. A moça cedeu e ele deu umas explicações sem pé e sem cabeça. A princesa mandou outra criada e saiu a mesma coisa. Foi ela mesma na terceira noite, e o rapaz pediu a camisa, recebeu-a e deu a explicação direita.

Quando foram todos no salão a princesa contou tudo direitinho. Atirei num veado, matei uma veada com uma veadinha. Assei a comida com lenha que fora do altar. Bebi água da macambira. Um jumento morto ia levando uma porção de urubus. Ficou sentado em cima do couro da veadinha.

Fizeram muita festa à princesa e o rei ia mandar dar uma surra 
no Amarelo quando este pediu que o deixassem falar. O rei deixou. O Amarelo disse:

'Quando no Paço cheguei

Três pombinhas encontrei,

Três penas já lhe tirei

E agora mostrarei!'

E foi mostrando as camisas das criadas. Quando ia puxando a camisa da princesa, esta correu para ele e disse que queria casar, que gostava muito do rapaz e só adivinhara porque ele mesmo dissera. O rei fez o casamento e foram todos muito felizes.”(Natal - Rio Grande do Norte)

\section{Uma outra versão compilada por Teófilo Braga narra:}

\section{A Princesa que Adivinha ${ }^{73}$}

“Havia uma princesa que adivinhava tudo, e o rei tinha prometido que se houvesse alguém capaz de lhe apresentar um caso que ela não explicasse, se fosse mulher dava-lhe uma grande tença, e se fosse homem casaria com ela; mas também quando a princesa adivinhava, mandava matar as pessoas que tinham vindo à corte apresentar-lhe o caso. Já não havia quem quisesse ir à corte apresentar adivinhas à princesa; vai senão quando uma mulher tinha um filho que passava por tolo, e diz-lhe o filho:

- Minha mãe, eu quero ir à corte dizer uma adivinha à princesa.

- Não sejas tolo, filho; o que é que tu lhe vais dizer que ela não adivinhe?

${ }^{73}$ BRAGA, Teófilo. Contos Tradicionais do Povo Português. Vol. I. Lisboa, Dom Quixote, 1994, p. 184-86 pas sim. 
O tolo tanto teimou, que se meteu a caminho, e como era longe agarrou de uma espingarda velha, e ei-lo se vai por aí fora. Andou, andou, e lá no meio do caminho viu estar um coelho num fraguedo e zás, ferra-lhe um tiro. Com tanta felicidade que matou caça; pegou nela, e com uma navalhinha esfolou-o, e nisto conheceu que era uma coelha, que trazia uma barrigada de coelhinhos. Não se importou com isso, e foi mais para diante e viu à beira da capelinha de um ermitão um breviário esquecido, e pegou nele, petiscou fogo e assou com as folhas do livro a coelha, comeu e foi andando sempre. Até que chegou à corte; não o queriam deixar entrar, porque parecia todo, porém ele tanto teimou dizendo que queria apresentar uma adivinha à princesa, que o deixaram entrar, na certeza de que ele ira a morrer como os outros que tinham vindo campar por espertos. Chegou a hora da audiência, e veio a princesa; o toleirão disse-lhe esta adivinha:
'Atirei ao que vi, Matei o que não vi, Entre palavras de Deus Assei e tudo comi’.

A princesa ouviu, tornou a ouvir, e pediu três dias para dar a explicação. O tolo ficou no palácio à espera da resposta, comendo e bebendo, de perna estendida, sem se lembrar que o podiam mandar matar. A princesa por mais voltas que deu ao miolo não atinava com a adivinha, e temendo de ter de casar com o tolo, mandou uma sua aia, muito em segredo, que lhe fosse pedir que dissesse como coisa particular o sentido da adivinhação. Foi a aia, mas o tolo disse que só se ela dormisse aquela noite no quarto com ele; a aia não queria, mas como a princesa lhe prometeu muitas riquezas, sempre se sujeitou e foi. O tolo teimava em não dizer, enquanto ela não 
tirasse a camisa, porque a queria em leitão; depois disse umas coisas que não eram a verdadeira explicação, e quando a aia adormeceu, escondeu-lhe a camisa, de modo que de madrugada, quando ela se foi, não teve tempo de a procurar. A princesa não se contentou com a explicação e mandou outra dama; aconteceu também o mesmo. Por fim foi a própria princesa, fiada em que a não conhecia; mas ele logo viu pela marca da camisa quem era, e escondeu-lha também, mas desta vez disse a verdadeira explicação da adivinha. Acabados os três dias ajuntou-se a corte, e a princesa veio e disse: A explicação da adivinha do aldeão é: Atirei ao que vi e matei o que não vi, é porque atirou a uma coelha que achou no caminho, a qual estava prenhe, morrendo por isso os coelhinhos. Entre palavras de Deus assei e comi, é porque assou tudo nas folhas de um Breviário com que fez uma fogueira. O rei ficou muito admirado do talento da sua filha, e disse que como ele aldeão tinha perdido, já não podia pretender a mão da princesa, e que se preparasse que ia a morrer. Vai ele, que se fazia mais tolo do que era, diz:

A princesa ainda não adivinhou tudo, porque ainda tenho a dizer outra adivinhação que juro que ela não é capaz de dar com o sentido.

A princesa mandou que ele falasse; e então disse:

\footnotetext{
'Quando no paço fiquei, Três pombinhas apanhei, E três penas lhe tirei; Se for preciso as mostrarei'.
}

A princesa ainda se pôs a considerar, mas ele tirou do seio a primeira camisa, e todos viram de que dama era; tirou a segunda, e ia para tirar a última quando a princesa, temendo a vergonha de se ver delatada diante da corte toda, virou-se 
para ele:

'Não mostres, não mostres, porque já vejo que és o homem mais ladino que tem vindo a esta corte, e caso contigo'.” (S. João de Airão - Minho)

Na versão de Adolfo Coelho o conto é denominado:

\section{As Três Lebres ${ }^{74}$}

"Havia noutros tempos um rei que tinha uma filha, que dizia que só se casaria com o homem que fosse capaz de inventar uma adivinhação que ela não adivinhasse. Correram ao palácio muitos príncipes e fidalgos, mas todos se foram sem que as suas adivinhações ficassem por adivinhar. Foi-se passando muito tempo e estas notícias corriam por muitas partes, até que chegaram aos ouvidos de certo aldeão muito esperto e ele, ao saber disso, dispôs-se logo a partir para o palácio, sem saber ainda o que havia de perguntar à princesa. Montou a cavalo, sem mais bagagem do que o seu livro de orações, e sem farnel de qualidade alguma. Durante o caminho teve fome e sede, mas não havia ali em tal descampado nem comer nem água; então o aldeão, olhando, viu morto no chão um coelho, tomou-o, e depois de o esfolar, fez uma fogueira do seu livro de orações, assou o coelho e comeu-o. A sede era, porém, cada vez maior; ele então fez correr muito o cavalo até que o suor lhe caía em bica; apanhou-o no seu chapéu e bebeu-o, e depois continuou a sua viagem. Chegado ao palácio, viu muitos fidalgos que perguntavam adivinhações à princesa e ela tudo adivinhava. Então ele, depois de todos terem falado, levantou-se e disse:

${ }^{74}$ COELHO, Adolfo. Contos Populares Portugueses. 5.ed. Lisboa, Dom Quixote, 1999, p.193-95 passim. 
'Comi carne sem ser caçada

Em palavras de Deus assada;

Bebi água que não foi do céu caída,

Nem também na terra nascida.

Adivinhai agora, princesa, se de tanto sois capaz.'

Então a princesa disse que pedia três dias para adivinhar, pois era esta a que maiores voltas lhe havia de fazer dar à cabeça. Ficou o aldeão no palácio à espera que a princesa adivinhasse; mas logo no primeiro dia foi ter com ele uma aia da princesa que lhe disse: 'Explicai-me o que hoje perguntastes à princesa e far-vos-ei tudo o que me pedirdes.' Respondeu o aldeão: 'Explicar-vos-ei tudo daqui a três dias, se me deixardes ficar esta noite no vosso quarto.' Disse logo a aia que sim, e fez uma cama no chão para o aldeão dormir nela. Deitou-se o aldeão e a aia, julgando que ele já dormia, deitou-se também; mas logo que viu que ela estava deitada, tirou-lhe uma saia que ela tinha despida e saiu do quarto. No dia seguinte foi ter com ele outra aia da princesa, a quem sucedeu o mesmo que à primeira. Finalmente, sem saber o que tinha sucedido às aias, foi a princesa ao terceiro dia ter com o aldeão, e ele disse-lhe também o mesmo que tinha dito às aias; mas em vez de tirar uma saia à princesa tirou-lhe o seu chambre de dormir, que era de finas rendas. No quarto dia, logo de manhã, foi o aldeão explicar a adivinhação às aias e à princesa; e à hora em que a corte estava toda reunida para ouvirem, a princesa respondeu logo: 'A carne sem ser caçada, em palavras de Deus assada, era um coelho que encontraste morto no caminho e que assaste no teu livro de orações. A água sem ser da terra nascida, nem do céu caída, era o suor do teu cavalo.' 'É verdade, disse o aldeão. Então o rei, levantando-se, ordenou ao aldeão que se fosse para a sua ter- 
ra pois nada tinha a esperar. Mas ele disse logo: 'Já que a princesa é tão inteligente, peço-lhe que adivinhe agora esta:

'Quando neste palácio entrei

Três lebres encontrei,

Todas três esfolei;

E as peles delas mostrarei'.

Ia para mostrar as saias das aias e o chambre da princesa, mas esta levantou-se logo e disse: 'Basta, basta, serás meu esposo, pois és o homem mais esperto que aqui tem vindo’.” (Coimbra)

\section{Na versão por Sílvio Romero, o conto chama-se:}

\section{O Matuto João ${ }^{75}$}

"Havia um homem de nome Manuel, casou-se com uma mulher chamada Maria e tiveram um filho que se chamou João. Os pais, por serem muito pobres, não lhe ensinaram a ler; porém João era muito ativo. Um dia saiu de casa com uma cachorrinha que sua avó lhe tinha dado e foi passear. No caminho soube que no 'Reino das três princesas' havia uma grande festa e um casamento, dentro de quinze dias, com uma das filhas do rei, se alguém decifrasse uma adivinhação. Já muitos homens tinham morrido na forca por não poderem decifrar a adivinhação.

João, chamado o 'amarelo’, voltou para casa e disse ao pai que ia pelo mundo afora ganhar a sua vida. O pai consentiu e a mãe lhe preparou um pão muito grande envenenado e arrumou-o na trouxa. João partiu com a sua cachorrinha. Não sabendo bem os caminhos, perdeu-se nas montanhas, e, de-

\footnotetext{
${ }^{75}$ ROMERO, Sílvio. Contos Populares do Brasil. Belo Horizonte, Itatiaia, 1985, p.109-10.
} 
pois de andar muito errado, deu numa campina já de noite. Aí dormiu. No dia seguinte passou ele um rio, que tinha tido uma grande enchente e onde viu um cavalo morto, e os urubus já lhe estavam dando cabo. Como havia correnteza, as águas puxavam o cavalo pelo rio abaixo. João fez reparo naquilo e seguiu o seu caminho.

O sol já pendia quando ele sentou-se debaixo de um pé de árvore para comer o seu pão, e nisto deu-lhe o coração aviso que não comesse sem experimentar em sua cachorrinha. Logo que ele deu do pão à cachorrinha, ela expirou. Muito sentido com isto, ele pegou-a nos ombros, e os urubus começaram a atrapalhá-lo. Para ver-se livre, ele enterrou a cachorra, mas os urubus a desenterraram, a comeram e morreram. João pegou nos urubus e pôs nas costas e seguiu. Chegou a uma estalagem, e, não vendo ninguém, entrou pela porta adentro. Lá no fundo avistou sete homens todos armados de espingardas. Estavam sem comer há três dias e logo que viram o João avançaram para ele e the tomaram os urubus. João largou-se a toda pressa e deixou-os atrás; mas vendo que o não seguiam voltou e achou-os todos mortos. Escolheu das sete espingardas a melhor e largou-se. Chegando adiante, encontrou uma grande campina; já morto de fome e sede, sentou-se debaixo de um arvoredo. Nisto voa do capim grosso uma 'iampupé'. O tiro errou e foi dar numa rolinha que estava entre as folhas. João apanhou a rola e a depenou; mas não achou com que fizesse fogo .para assá-la. Tinha ali uma 'santa-cruz' e tirou dela uma lasca e fez fogo, assou a rola e comeu; mas tinha muita sede e, não achando água, pegou um cavalo, que andava ali pastando, montou nele e pôs-se a correr até o cavalo ficar bem suado - a ponto de correr suor e ele aparar e beber. Seguiu sua viagem e passou num campo e viu uma cova onde havia uma caveira; falou-lhe e notou que a 
caveira também lhe falava. Mais adiante encontrou um burro amarrado debaixo duma árvore a cavar com os pés e conheceu que o burro cavava uma botija de dinheiro. Seguiu e foi ter ao palácio do rei e levar a sua adivinhação à princesa, certo de que ela não acertaria. Apresentou-se o João e disse que era pretendente à mão da princesa; pois ela era incapaz de decifrar a sua adivinhação. Riram-se muito dele. 'Ora! disseram, quando outros homens sábios não saíram-se bem, tu que é um pobre ‘matuto’ e ‘amarelo’ é que hás de casar com a filha do rei!' o 'matuto' insistiu e foi falar ao rei. O rei lhe disse: 'Sabes tu a quanto te arriscas?' João respondeu que a tudo estava disposto. Chamada a princesa e muito confiada em si e debicando o rapaz manda-lhe que proponha a sua adivinhação. O matuto assim falou:

'Saí de casa com massa e pita;

A massa matou a Pita,

A pita matou três,

Os três mataram sete,

Das sete escolhi a melhor:

Atirei no que vi

E matei o que não vi,

Com madeira santa

Assei e comi;

Bebi água sem ser dos céus, Vi o morto carregando os vivos, O que o homem não sabe, Sabia o jumento:

Ouça tudo isto para seu tormento’.

A princesa mandou repetir, e não foi capaz de decifrar. E casou com o João.”

(Pernambuco) 
As cinco recriações apresentadas reúnem em sua estrutura narrativa elementos similares aos encontrados em Sua Alteza A Divinha. Uma vez mais, a perspicácia, concretizada através do uso correto da palavra, será o dispositivo de acesso à personagem masculina que tenta a sorte perante a Corte.

Amarelo, ou o aldeão esperto ou João (em O Matuto João) é o tolo que ressurge, ao longo da narrativa, mostrando sua habilidade discursiva. "Bem longe da cidade morava uma viúva com um filho amarelo e doente, parecendo mesmo amalucado." ${ }^{76}$, afirma o narrador em A Adivinha do Amarelo. Mas, em A Princesa Adivinhona, ainda que o rapaz seja adjetivado de amarelo, “... é sabido como ele só." ${ }^{, 77}$ Independente da denominação atribuída ao aventureiro, ele representa a personificação do homem simples do povo, freqüentemente iletrado, acostumado ao ambiente dos lugarejos e aldeias, contudo, detentor da sabedoria advinda da experiência com os jogos, oráculos, com as apostas na praça pública.

Dos contos selecionados, somente os recolhidos por Cascudo e Romero apresentam o bolo de carne como elemento antagônico à realização da aventura empreendida pela personagem.

Neste aspecto, o que diverge, na recriação de Angela Lago, é a razão do envenenamento do pão. A antagonista que o prepara tenciona, ilicitamente, apoderar-se de um bem material de Louva-a-deus. Em Cascudo e Romero observa-se que é a mãe quem tenta decidir a sorte do filho, impondo-lhe até mesmo a morte como castigo por infringir uma ordem sua.

Podemos observar que os motivos que levam à formulação das adivinhas, no trajeto da personagem até o palácio, pouco diferem nas versões apresentadas. (O cão, de modo geral, come o alimento envenenado. Os urubus, em número de sete, devoram o cão morto e também sucumbem. Há a inserção do burro que cava um tesouro, a escolha da melhor espingarda e a personagem é

\footnotetext{
${ }^{76}$ CASCUDO, Luis da Camara. Literatura Oral no Brasil. p.321.

${ }^{77}$ Idem, Contos Tradicionais do Brasil. p.290.
} 
sempre favorecida no momento da caça). O acaso, então, figura como elemento de destaque no conto e estará, constantemente, favorecendo o protagonista.

Outro ponto divergente entre os contos compilados por Cascudo, Braga, Coelho e Romero e a recriação apresentada por Angela Lago, é o meio de punição imposta aos candidatos perdedores. Em A Princesa Adivinhona, o narrador não menciona sobre a pena capital, “... os candidatos apanhavam uma surra, voltando envergonhados. ${ }^{, 78}$, aspecto assinalado em Adivinha do Amarelo, A Princesa que Adivinha e O Matuto João. No texto de As Três Lebres não há punição, o perdedor volta para sua terra sem nada levar.

Verifica-se, entretanto, que o risco de morte não abala os candidatos, a não ser em Sua Alteza A Divinha, quando à personagem Louva-a-deus é atribuído um grau maior de ingenuidade. Amarelo, por sua vez, caracteriza a figura do caboclo experiente, malicioso, que, apesar do risco a que se submete ao entrar no jogo, conhece seu poder de sedução sobre as mulheres e sabe que pode ganhar. A personagem, então, ciente da tentativa de manipulação da princesa, para a obtenção das respostas, aceita o jogo por ela estipulado: deixar-se seduzir pelas criadas. Amarelo, contudo, inverte o jogo e fixa como regra: a resposta pela camisa de cada uma. Além de omitir a resposta correta “... Amarelo contou muita história mas não explicou a resposta."79, toma-lhes uma peça de roupa como trunfo. Perante o fracasso das empregadas, a princesa, pessoalmente, faz a sua investida. Ela perde a camisa, mas obtém a resposta.

A personagem, pressupondo a represália, uma vez que a princesa conhecia a resposta e a declinaria perante a Corte, elabora, baseado no seu envolvimento com as três mulheres, uma nova adivinha. Com receio de expor a sua intimidade à Corte, já que Amarelo estava de posse de uma roupa sua, a princesa revela ter obtido as respostas através do próprio aventureiro: “ - Não mostres, não mostres, porque já vejo que és o homem mais ladino que tem vindo a esta

\footnotetext{
${ }^{78}$ CASCUDO, Luis da Camara. Contos Tradicionais do Brasil. p.290.
} 
corte, e caso contigo." ${ }^{80}$

Em Sua Alteza A Divinha, por não estar registrado no texto o segmento que relata o envolvimento do aldeão com as aias do palácio, o desfecho dá-se com as respostas acidentais de Louva-a-deus às perguntas. Nas recolhas apresentadas, com exceção de O Matuto João, quando a princesa dá-se por vencida por ocasião do questionamento elaborado por João, baseado em sua viagem, as demais recriações são, em nosso parecer, de cunho malicioso. Teixeira, tecendo considerações sobre as adivinhas dentro da cultura portuguesa, salienta: “As adivinhas populares são divertimentos muito a gôsto de nosso povo.

Há as mais simples e as mais complicadas; as que se revestem de caráter essencialmente humorístico e as que têm por finalidade encabular.",1

Acreditamos que a omissão do envolvimento do protagonista com as moças, em Angela Lago, insere a narrativa dentro do universo infantil e acentua o lado da competição, da torcida pela adivinhação, na qual estão participando a princesa, o leitor, o narrador. Do mesmo modo, o narrador convida o pequeno leitor ao exercício das adivinhas, no ato de memorizar e posteriormente recriar.

Podemos afirmar que, diferentemente dos demais aventureiros, Louva-a-deus pode ser classificado como o verdadeiro bobo da corte que, inocentemente vai ao palácio tentar a sorte, pensando que será fácil; igualmente, a postura da princesa revela o desejo de vitória de Louva-a-deus, pois ela cruza os dedos em sinal de sorte para o pretendente.

\footnotetext{
${ }^{79}$ Idem, ibidem, p.322.

${ }^{80}$ BRAGA, Teófilo. Contos Tradicionais do Povo Português. p.186.

${ }^{81}$ TEIXEIRA, Fausto. Estudos de Folclore. Belo Horizonte. Editorial Panorama, 1949, p.97.
} 
Relação de Pranchas referentes ao capítulo 2.

$\begin{array}{ll}\text { Prancha } 1 & \text { p.50 } \\ \text { Prancha } 2 & \text { p.58 } \\ \text { Prancha } 3 & \text { p.59 } \\ \text { Prancha } 4 & \text { p.62 } \\ \text { Prancha 5 } & \text { p.64 } \\ \text { Prancha 6 } & \text { p.65 } \\ \text { Prancha 7 } & \text { p.69 } \\ \text { Prancha } 8 & \text { p.71 } \\ \text { Prancha 9 } & \text { p.73 } \\ \text { Prancha } 10 & \text { p.74 } \\ \text { Prancha } 11 & \text { p.75 } \\ \text { Prancha } 12 & \text { p.75 } \\ \text { Prancha } 13 & \text { p.76 } \\ \text { Prancha } 14 & \text { p.77 } \\ \text { Prancha } 15 & \text { p.77 } \\ \text { Prancha } 16 & \text { p.79 } \\ \text { Prancha } 17 & \text { p.81 } \\ \text { Prancha } 18 & \text { p.85 }\end{array}$




\section{Capítulo 3 A PRAÇA, O PALCO, A ARTE NO ENREDAR \\ DE 10 ADIVINHAS PICANTES}

“Que significa o riso? Que há no fundo risível? Que descobriremos de comum entre um esgar de palhaço, um jogo de palavras, (...) uma requintada cena de comédia?”

Henri Bergson

\subsection{A expressão em texto verbal}

\section{1 obra é norteada pela competição desencadeada entre as duas} personagens, feminina e masculina, montada através de sucessivas adivinhas lançadas e, imediatamente decifradas pelo leitor, que as interpreta ou busca suas respostas, ao abrir as abas das páginas que as escondem.

De estrutura verbal e visual similar à obra anterior Sua Alteza A Divinha, a narrativa ganha movimento devido ao ritmo imposto à leitura, primeiramente, devido à sintetização do pensamento, do seqüenciar da estória através de sentenças curtas. Esse texto, ainda que graficamente demonstrado no papel, possui tal pluralidade discursiva na sua totalidade, dada a sua 
cumplicidade com a linguagem verbal, ao se verificar a fala transformar-se em escritura e a escritura revestir-se de aspectos da linguagem oral. O leitor é facilmente induzido a tomar parte no jogo de palavras “...o que é, o que é?” e, aventurar-se na condição de espectador, fora do palco, junto às personagens, a solucionar as adivinhas. O recurso da ilustração extrapola o conteúdo textual, através do amplo recontar. Detalhes como a visão dos bastidores do palco, a movimentação das cortinas, representada pelo abrir e pelo fechar da aba da página e a inserção de elementos (bilhetes, pássaros, insetos) revestem a ilustração de significados que o texto verbal não menciona.

Expressões de uso popular revelam a intencionalidade da artista em resgatar aspectos da tradição oral. "Meu amor, meu vagalume, qual a cor que tem perfume?"1 e "Você sabe, coração, quando duas meninas dormem no mesmo quarto, que horas são?”2 A informalidade contida nas sentenças, inseridas na própria adivinha, dada a disposição dos vocábulos “meu amor”, “meu vagalume” e "coração", demonstra a relação de parceria entre as personagens num mundo que somente pode ser apreendido através da linguagem, em suas diferentes nuanças. Dessa forma, a interação entre os signos da fala e da escritura, ou seja, o diálogo alicerçado no texto e a escritura encapsulada na linguagem oral, posiciona o leitor como ouvinte, aquele que atende aos apelos do narrador-personagem através do relato, da declinação das adivinhas; além disso, o entrelaçamento dialógico ${ }^{3}$ entre 0 texto e a ilustração torna a obra fecunda, aspecto que permite o descortinar do palco, na hora do espetáculo. Abrem-se as cortinas dos significados mais amplos do narrar. O desconhecido, tudo que está oculto, seja pelas palavras ou

\footnotetext{
${ }^{1}$ LAGO, Angela. 10 Adivinhas Picantes. Belo Horizonte, RHJ, 1989, p.2.

${ }^{2}$ Idem, ibidem, p.4.

${ }^{3}$ Sobre dialogismo consultar BAKHTIN, Mikhail em A Poética de Dostoiévski. Trad. Paulo Bezerra. Rio de Janeiro, Forense-Universitária, 1981.
} 
pela intencionalidade do pincel, produz expectativa no observador.

Velado pelas cortinas, está, no emaranhado do vir a ser, o verbal transformando-se em visual e este incorporando à palavra, o resgate de aspectos da cultura medieval. Por sua vez, esse resgate acha-se alicerçado na idéia explícita de jogo, de competição, como atributo natural do ser, e de ludicidade, através do poder mnemônico das personagens e do leitor.

\subsection{Pegadas do tempo}

1 a sociedade medieval, plena na transmissão oral das tradições, a memória aparece como atributo indispensável aos contadores de estórias, àqueles que narravam feitos, declinavam ditos populares, gírias e adivinhas.

Os improvisadores, cancioneiros ou intérpretes, como eram chamados, organizados ou não em grupos, eram pessoas simples do povo que, pelo caráter nômade, tornaram-se os “... porta-vozes do mundo medieval”, propagadores dos mitos e de todo o arsenal que compunha o imaginário, garantindo assim, a sobrevivência dos laços sociais vigentes na época. Citando Pidal, Zumthor salienta que “a 'tradicionalidade' (...), 'assimilação do mesmo', procede da ‘ação contínua' e ininterrupta das variantes”, No entanto, essa prática popular, em algumas cidades burguesas, era vista com certa

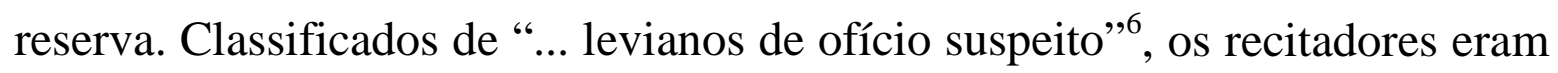
considerados indivíduos de vida fácil, que perambulavam de um lugar para outro; saltimbancos que se vestiam de maneira extravagante, provocando alvoroço onde quer que chegassem. Esses “juglares”, designados, segundo

\footnotetext{
${ }^{4}$ ZUMTHOR, Paul. A Letra e a Voz. Trad. Amálio Pinheiro; Jerusa P.Ferreira. São Paulo, Companhia das Letras, 1993, p.65.

${ }^{5}$ Idem, ibidem, p.145.

${ }^{6}$ ZUMTHOR, Paul, op. cit., p.65.
} 
Pidal, como “... todos los desheredados de la naturaleza y de la fortuna que poseíam alguna aptitud artística y que gustaban de la vida al aire libre (...).”” surgiram em diferentes regiões da Europa, ao longo da Idade Média. ${ }^{8}$

A presença desses menestréis, em constante recriação, representou para a sociedade medieval o extravasamento, a liberação da alegria (em cerimônias e rituais), além do encapsulamento dos dogmas clericais, o medo da punição e da severidade dos castigos infernais articulados pela Igreja.

Os oradores sempre estiveram ligados às festas públicas e particulares como casamentos, jantares e batizados da nobreza, atuando como intérpretes da poesia oral. Como recompensa, muitos conseguiram dos nobres, reconhecimento e fortuna, aspecto que os isentaria, segundo Zumthor, da condição de seres marginalizados, como supunham alguns núcleos sociais.

\subsection{Praça-palco-livro}

nível de comunicabilidade entre os trovadores e o seu público, nas ruas e praças, utilizando-se de uma linguagem vulgar, oposta à linguagem clássica utilizada pela classe dominante, configurado na narrativa em atores, leitor e palco, dá-se inicialmente pela credibilidade que este último endereça ao primeiro, sintetizada na performance das personagens no tablado, visando à aprovação do espectador. Por outra vertente, os gestos, a voz do intérprete, o dizer poético ecoam e capturam os sentidos dos ouvintes que se sentem propensos a dar vazão à tendência natural de tentar reter na memória

\footnotetext{
${ }^{7}$ PIDAL, Menéndez Ramón. Poesía Juglaresca Y Juglares. Buenos Aires, Espasa - Calpe Argentina, 1942, p.12.

${ }^{8}$ As manifestações estudantis nas praças públicas, que parodiavam as farsas e moralidades da sociedade burguesa no século XVI remetem aos recitadores de outrora.
} 
aquilo que foi narrado, cantado. Elucida Zumthor que:

"No caleidoscópio do discurso que faz o intérprete de poesia na praça do mercado, na corte senhorial, no adro da igreja, o que se revela àqueles que o escutam é a unidade do mundo. Os ouvintes precisam de tal percepção para (...) sobreviver.”,

Essa é também uma das razões por que 10 Adivinhas Picantes seduz: há na fala das personagens uma acentuada conotação irônica. Vejamos um exemplo: “Ó deusa das horas eternas! O que você tem bem no meio das pernas?”"10 No vocativo “deusa das horas eternas” percebe-se a zombaria velada, afinal, depois de uma evocação de tamanha reverência, não era de se esperar uma pergunta tão marota, geradora de ambigüidade. Em seguida temos a adivinha, proposta pela figura que caracteriza a princesa, que se inicia desse modo: “Ó mais reles dos humanos! O que você faz em algarismos romanos?” Esse vocativo “Ó mais reles dos humanos!” revela uma faceta especial desse duelo de palavras, pois nele está implícita a associação de idéia que a princesa deve ter feito, motivada pela sugestão maliciosa que a adivinha do adversário propôs e a conseqüente irritação, que a fez, imediatamente, após ser interpelada, retribuir o desafio de adivinhações, utilizando-se de um vocábulo rude (reles) para dirigir-se a ele. Esse jogo oral agrada ao público (leitor), que se sente envolvido pelo despojamento da linguagem e irreverência dos atores em cena, reconhecendo no espetáculo traços do seu tempo. Seja, portanto, na praça pública, no palco, ou na página do livro, a voz do cantador universalizase, porque ganha sonoridade, expressividade. No conto, a voz dos atores aproxima a platéia, estabelece vínculos, por isso entretém, diverte, traz

\footnotetext{
${ }^{9}$ ZUMTHOR, Paul A Letra e a Voz. p.74.

${ }^{10}$ Idem ibidem, p.6.
} 
conhecimento, resgata o espírito popular medieval. Benjamin salienta que:

“... a relação ingênua entre o ouvinte e o narrador é dominada pelo interesse em conservar o que foi narrado. Para o ouvinte imparcial o importante é assegurar a possibilidade da reprodução. A memória é a mais épica de todas as faculdades. (...) A reminiscência funda a cadeia da tradição, que transmite os acontecimentos de geração em geração. (...) Ela tece a rede que em última instância todas as histórias constituem entre si." ${ }^{11}$

Observe-se que a dobra da página que esconde respostas, paradoxalmente revela uma intenção. A resposta está lá, na aba da página, ou seja, quem a formulou já a conhece. Ao buscar a resposta, o leitor que não a conhece, entra no jogo do narrador - o jogo de brincar com a imaginação, o jogo do contar.

O recurso da metalinguagem, igualmente, auxilia na elucidação da proposição. O segmento “... a cor que tem perfume (...)”,"12 da primeira advinha, possui como representação gráfica, um botão de rosa sustentado pela mão da personagem masculina. Sobre a flor, propriamente dita, uma pequena formiga estabelece um canal de comunicação com o leitor servindo-se de dois códigos: a linguagem escrita, pelo emprego do vocábulo "rosa" - aqui está a rosa - ela é a resposta e a linguagem gestual quando, pelo dedo indicador, sinaliza o objeto mencionado, quebrando, dessa forma, a expectativa do leitor pela resposta da adivinha.

No mesmo recorte, um outro inseto, que sugere, pelo traçado, um

\footnotetext{
${ }^{11}$ BENJAMIN, Walter. Magia e Técnica, Arte e Política. Trad. Sérgio P. Rouanet. 7.ed. São Paulo, Brasiliense, 1994, p. 210-11.

${ }^{12}$ LAGO, Angela. 10 Adivinhas Picantes. p.2.
} 
louva-a-deus, toca ligeiramente o espinho da rosa. Ao lado do desenho a citação: “muito picante”. Percebemos que a palavra picante, neste aspecto, desdobra-se em outro contexto: picante passa a ser o espinho da rosa, razão que provoca o riso. A interação entre texto e ilustração dá-se pela relação existente entre o desenho (a rosa cujo espinho está em evidência) e a citação “esta é picante”, referindo-se à adivinha. O verbal, que é introduzido, então, com o sentido malicioso - excitante - adjetiva as adivinhas, interagindo com o visual, que qualifica o espinho de picante. Desse modo a adjetivação dos elementos remete-nos ao título da obra.

\subsection{O recontar pela ilustração}

$\prod$ a ilustração, a disposição do cenário, a posição das personagens em cena estão carregadas de caracteres que revelam traços do medievalismo $^{13}$, como o recurso, que aponta para autores anônimos (como os medievais), com a utilização de papel de espessura acentuada que dificulta o recurso da transparência da imagem.

As abas que se formam nas laterais das páginas sugerem a movimentação de cortinas suspensas por argolas, presas em um bastão, representado no desenho por uma reta que se alonga de um extremo a outro da página. Paralela a esta reta, uma outra linha demarca horizontalmente o espaço. Trata-se de uma sala de espetáculos, cujas cortinas mantêm-se afastadas em meio a uma apresentação teatral. As cenas assemelham-se a um quadro cinematográfico, quando as tomadas são filmadas em “travelling” ${ }^{14}$.

\footnotetext{
${ }^{13}$ Os desenhos que possuem o mesmo caráter estilístico de Sua Alteza A Divinha evocam, segundo depoimento de Angela Lago, sua própria infância, os livros lidos e o desejo de recuperação de memórias.

${ }^{14}$ Travelling é o movimento da câmera sobre um carrinho ou rodas, num eixo horizontal e paralelo ao movimento da personagem ou ao assunto que está sendo filmado. LEONE, Eduardo; MOURÃO, Maria Dora. Cinema e Montagem. Série Princípios. São Paulo, Ática, 1987, p.81.
} 
“A projeção do código cinematográfico sobre o literário-infantil é uma forma de a gestualidade, a fusão e a simultaneidade das formas orais penetrarem no espaço narrativo.”15 argumentam Palo e Oliveira. O abrir e fechar da dobra da página permite ao observador identificar vários planos, através dos quais se desenrola o enredo.

A estrutura verbal com o emprego de sentenças curtas, associada ao componente visual, impõe ritmo e dinamicidade à narrativa, nos momentos de declinação e tentativa de solução das adivinhas: "Sob este céu de anil! Qual a figura de mais moral no Brasil?”16 Isso é corroborado pela flexibilidade dos movimentos das personagens e quebras de página.

As personagens, em meio a quadros diferentes de um espetáculo, levam à idéia do cômico pelo tom paródico ${ }^{17}$ que expressam no ato da performance no palco. A personagem masculina ${ }^{18}$, através da desproporção do braço ao tamanho do corpo, alcança, por trás das cortinas, uma rosa, materializando, assim, a resposta à adivinha, conforme se pode observar através das pranchas números 1A e 1B.

\footnotetext{
${ }^{15}$ PALO, Maria José; OLIVERIA, Maria Rosa D. Literatura Infantil. Voz de Criança. Série Princípios, São Paulo, Ática, 1986, p.61.

${ }^{16}$ LAGO, Angela. 10 Adivinhas Picantes. p.8.

${ }^{17}$ Neste seguimento a paródia pode ser entendida segundo BAKHTIN, Mikhail em A Poética de Dostoievski.p. 147, como o discurso que “deve ser sentido como o de um outro. Assim, num único discurso podem-se encontrar duas orientações interpretativas, duas vozes. Assim é o discurso parodístico.

${ }^{18}$ Observe-se que a personagem masculina de 10 Adivinhas Picantes remete à personagem Louva-a-deus de Sua Alteza A Divinha devido às suas características físicas e comportamentais.
} 

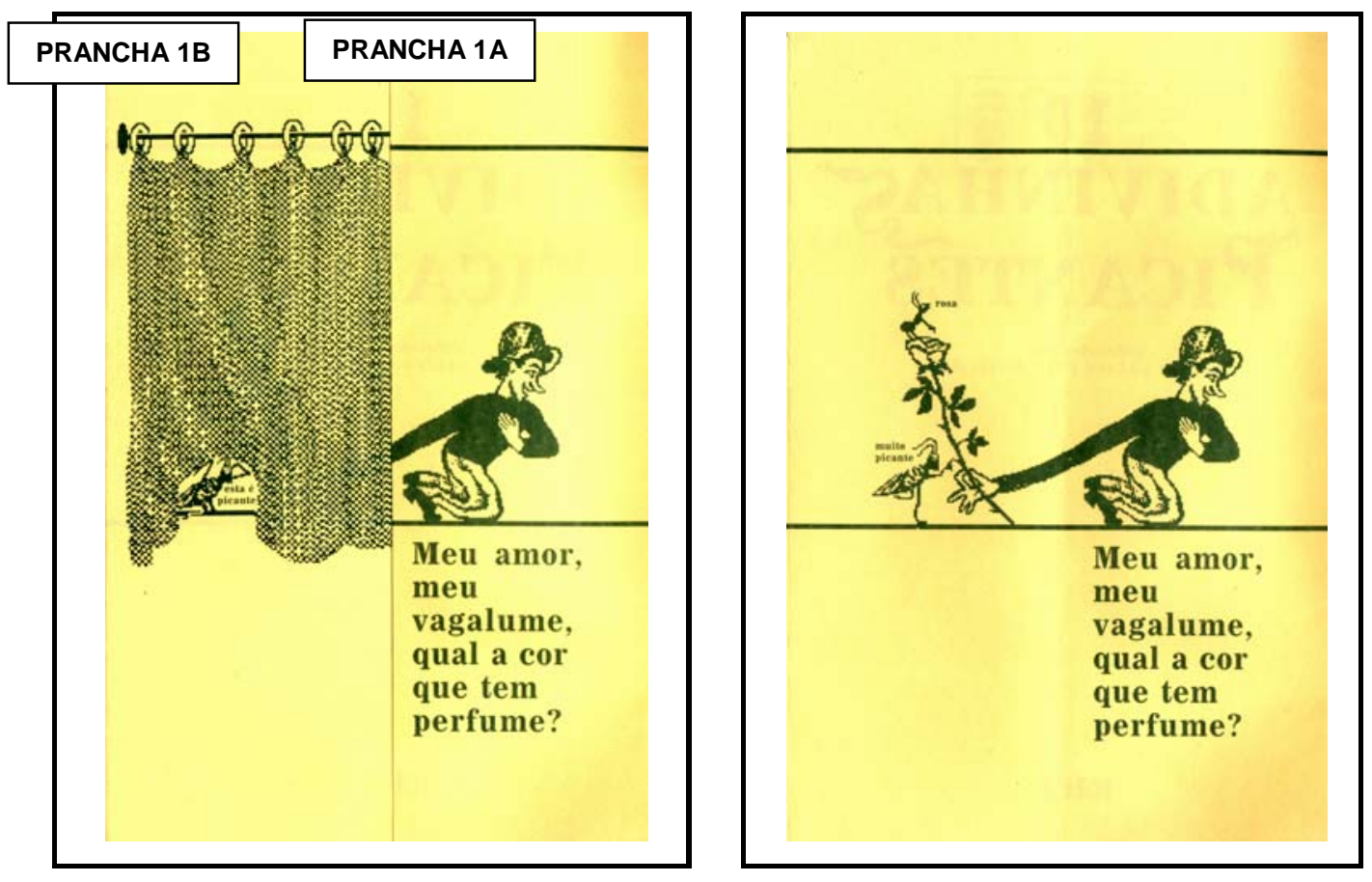

Na seqüência, a representante feminina, exagerada no prolongamento do braço esquerdo, apodera-se do espelho que, igualmente, foge aos padrões convencionais de tamanho.(vide prancha número 2)

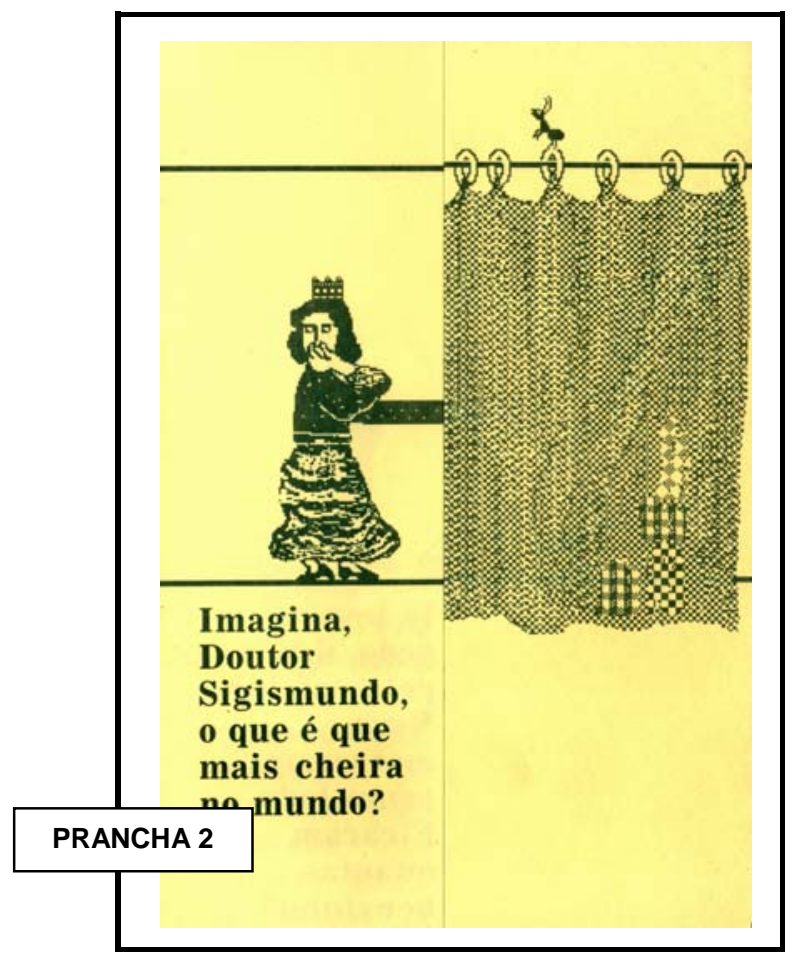


O cenário, que oscila entre o azul e o cinza, prevê outras presenças em cena. Pequenos insetos e pássaros atuam como personagens coadjuvantes, como sinalizadores das respostas. O ápice corresponde aos momentos esfuziantes da narrativa quando expressões tais como: "Pelos anjos que têm asa!”"19 e “Ó céus! Ó terra! Ó obra!”20 são pronunciadas pelas personagens masculina e feminina, respectivamente.

A comicidade que margeia o texto é atribuída, não somente à idéia ligada ao automatismo, por meio da estrutura frásica utilizada reiteramente; mas à promoção do clima de cumplicidade entre leitor e princesa, estabelecido através do emprego que esta faz de vocábulos como “amor”, “vagalume”, “benzinho”, “coração”, em sua fala, ao dirigir-se à personagem masculina, que parece não se dar conta da ironia presente na fala da princesa. Nesse aspecto, o leitor assume o papel de quem, assistindo ao desafio de adivinhas, ri do "bobo", que não entende o sentido das palavras que lhe são dirigidas.

Em cena, as personagens ocultam um jogo de sedução que, de acordo com seu direcionamento, envereda para o cômico.

\footnotetext{
${ }^{19}$ LAGO, Angela. 10 Adivinhas Picantes. p.9.

${ }^{20}$ Idem, ibidem, p.10.
} 


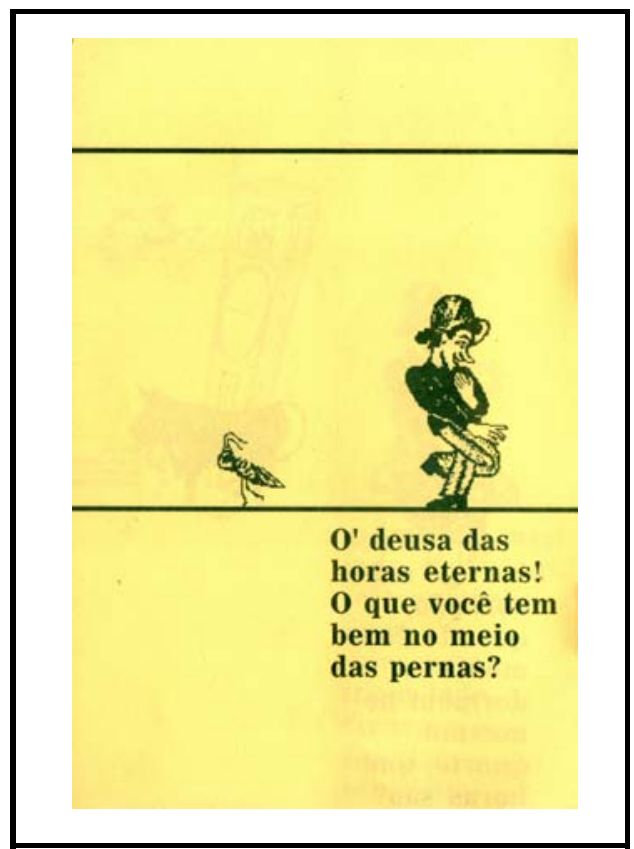

Na prancha número 3 o desenho referente a esse segmento enfatiza o contorno das pernas entrelaçadas do jovem, enamorado pela princesa, denunciando uma falsa timidez, postura que combina com a expectativa do espectador de entender o vocábulo picante no sentido erótico e daí a cena proporcionar o riso. Os pés delicados da princesa que ligeiramente remetem a passos imperfeitos de ballet, (prancha número 4) revelam uma superficial Imparciali-
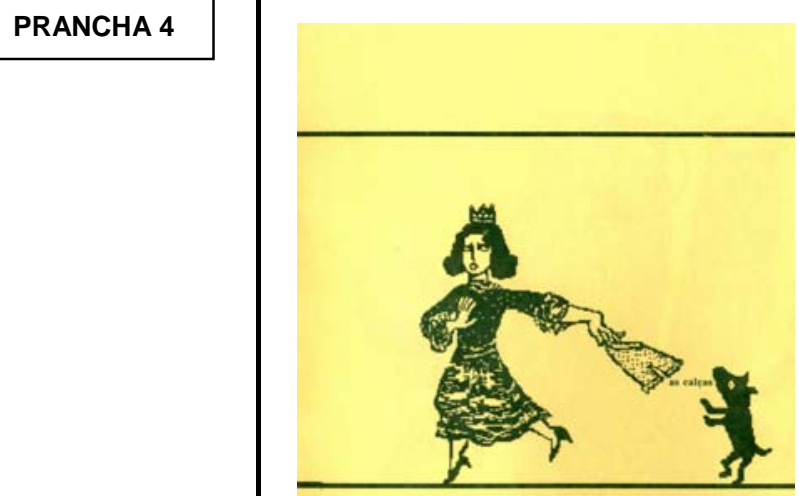

Sob este céu de anil! Qual a figura de mais moral no

Brasil? 
dade em seu comportamento, alheio à realidade, despreocupado com a presença do pretendente incansável nos argumentos de conquista. ${ }^{21}$

O tempo da narrativa é marcado pelo corte de cena, na virada rápida da página. O abrir e fechar da dobra da página contribui para enfatizar os intervalos durante o espetáculo. Este recurso provoca expectativa no leitor que, ávido de curiosidade, vai em busca das respostas, sinalizadas pelo narrador, que podem lhe desencadear o riso.

A estrutura verbal dita as diretrizes, fornece pistas ao leitor de como proceder nas várias etapas da narrativa. Procedimentos como "Só abrir depois de adivinhar as duas ${ }^{22}$ (adivinhas) influencia o comportamento do observador que pode optar por seguir a sugestão do texto ou infringir a regra, conhecendo antecipadamente a resposta. O leitor, e muito freqüentemente a criança, rompendo então, com o momento de expectativa, que antecede a decifração da adivinha, “cai em tentação" e abre a cortina, inteirando-se da resposta. Essa possibilidade, ou seja, essa ruptura das regras do jogo que o narrador permite ao leitor, faz parte de uma estratégia maior: a elaboração de uma brincadeira às avessas - fazer tudo ao contrário. Desse modo, reafirma-se a ludicidade tão apreciada pela criança - em especial - pelo leitor, aquele que gosta de desafiar as regras do jogo ${ }^{23}$, criando outras novas e de mesmo modo, sedutoras.

A ilustração da contra-capa preserva o caráter expressivo das personagens de mãos entrelaçadas, uma em frente da outra. Com a perna

\footnotetext{
${ }^{21}$ As cenas evidenciam a comicidade porque se trata de imagens que se assemelham ao real. ARISTÓTELES, apud MACHADO, Irene A. em O Romance e a Voz. Rio de Janeiro, Imago, 1995, p.180 considera o homem o único ser que provoca o riso, porque, sem dúvida, é o único que também ri.

${ }^{22}$ LAGO, Angela, op. cit. p.5.

${ }^{23}$ No contexto de 10 Adivinhas Picantes, parece-nos que a intrusão "Só abrir depois de adivinhar as duas" é mais uma brincadeira da autora, reproduzindo uma voz autoritária de quem impõe regras rígidas em situações em que não se faz necessário, limitando-se assim a experiência humana de encontrar novas possibilidades.
} 
esquerda, ligeiramente inclinada para trás, a princesa sorri para o parceiro que mantém os pés voltados para o lado interno dos joelhos. Desatento aos próprios movimentos, a personagem parece brincar com as mãos da princesa, postura que poderia retratar o início de um relacionamento afetivo ou remeter a uma prática infantil quando da relação de amizade e união entre as partes, como demonstra a prancha número 5.

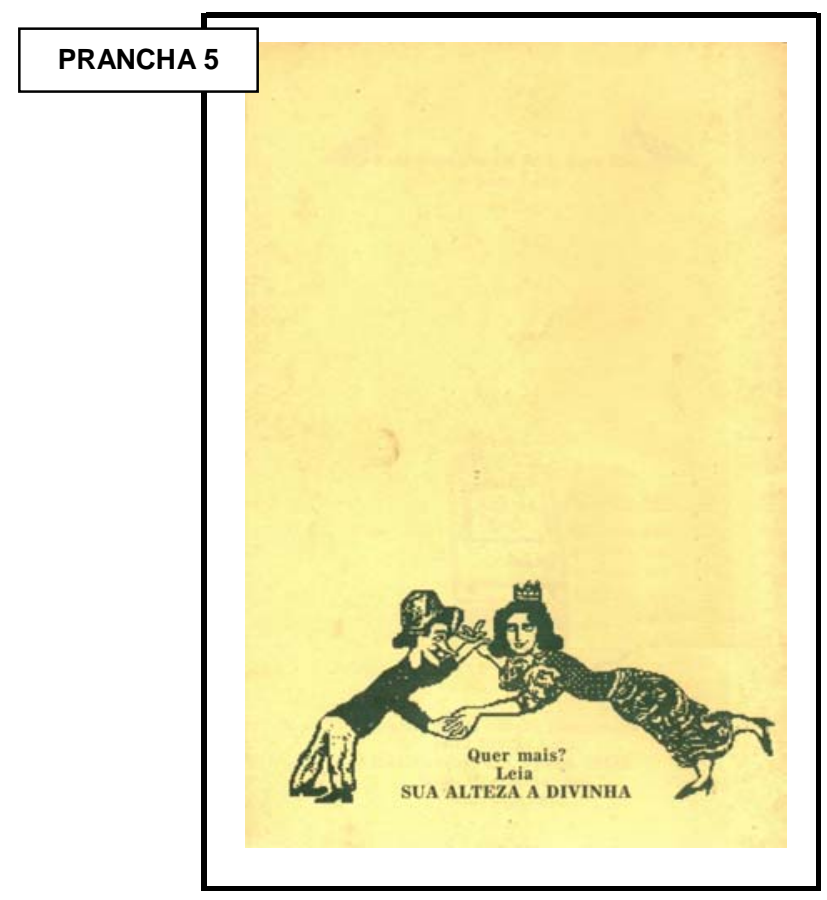

Por fim, admitindo-se que 10 Advinhas Picantes e Sua Alteza A Divinha são obras imbricadas, do ponto de vista estilístico e temático, compreensível se faz o emprego comum dos mesmos recursos. O processo de inserção do desenho na representação da letra, notadamente utilizado em Sua Alteza A Divinha, concretiza-se na capa de 10 Adivinhas Picantes. 
Observa-se que as letras "s" e "p", dos vocábulos "adivinhas" e "picantes", conforme prancha número 6, assemelham-se a pequenas cobras com a língua em evidência, cuja presença, no contexto narrativo explorado, merecem algumas considerações.

PRANCHA 6

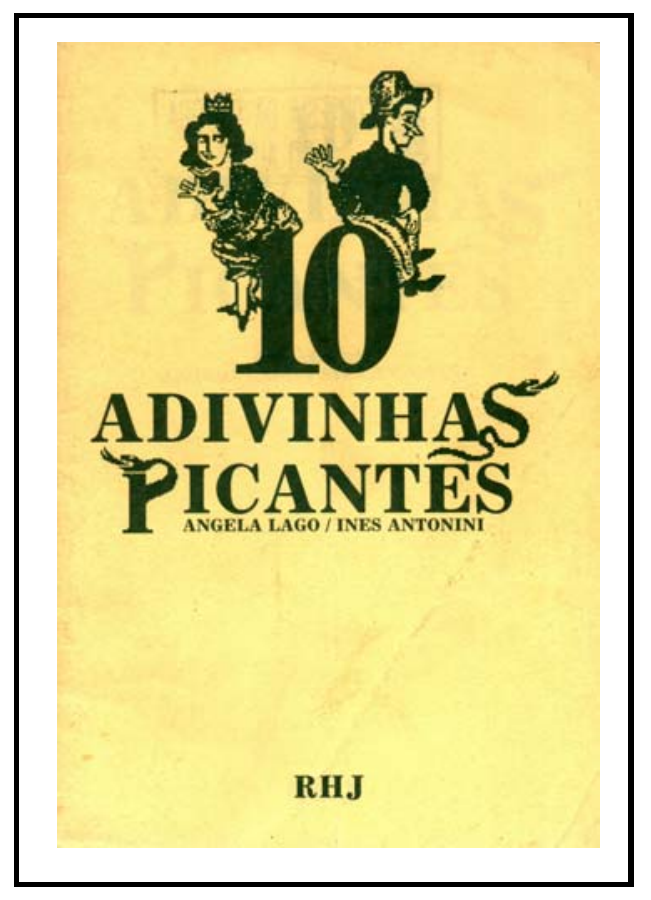

Em primeiro lugar, a língua da cobra, na palavra picante, acentua seu próprio significado e; em seguida, a palavra picante é que faz referência à língua da cobra. Por redundância se classifica a língua da cobra de picante, ou seja, é capaz de picar. Mais um estimulante jogo polissêmico entre palavra e ilustração.

De acordo com o olhar de cada leitor, a cobra pode estar ali presente, aludindo ao poder de sedução exercido pelas palavras sobre as pessoas. Associada, tradicionalmente, à queda de Adão no Jardim do Éden, quando, a cobra, após seduzir Eva a experimentar um fruto proibido, sugerelhe que ofereça o mesmo fruto ao homem. De acordo com o mito, ambos são seduzidos pela língua enganosa da cobra. Julgamos coerente interpretar a 
presença das cobras sobre as palavras “adivinhas" e "picante”, como forma de reforçar que, numa prova de adivinhas, ganha quem melhor souber lidar com as palavras, ou seja, quem souber decodificá-las, perceber como se camuflam, aplicar-lhes significações novas. Ainda podemos apontar outro significado para as cobras: as línguas em evidência podem anunciar o perigo de "queda" para aquele que não souber decifrar a charada proposta pelo outro.

Na contra capa da obra, encontra-se uma observação: "Quer mais? Leia Sua Alteza Advinha.”, cuja estrutura frasal nos permite reconhecer a voz de Angela Lago sobreposta à voz do narrador, infringindo mais uma vez as regras tradicionais do contar, rompendo a ordem da brincadeira, subordinando - no contexto da narrativa a nobreza e a linguagem formal ao popular e à oralidade. 
Relação de Pranchas referentes ao capítulo 3.

$\begin{array}{ll}\text { Prancha 1A } & \text { p.111 } \\ \text { Prancha 1B } & \text { p.111 } \\ \text { Prancha 2 } & \text { p.111 } \\ \text { Prancha 3 } & \text { p.113 } \\ \text { Prancha 4 } & \text { p.113 } \\ \text { Prancha 5 } & \text { p.115 } \\ \text { Prancha 6 } & \text { p.116 }\end{array}$




\section{Capítulo 4 \\ O ESCAVAR DO IMAGINÁRIO EM INDO NÃO \\ SEI AONDE BUSCAR NÃO SEI O QUÊ}

"Se a terra é redonda, onde fica o fim do mundo?”

Camila -08 anos

\subsection{O continuum do contar}

\section{A obra narra a trajetória de “...um menino muito zonzo. Vira e} mexe, ele vinha com a mesma resposta: - Sei não (...) foi se apaixonar por uma princesa muito sabida, que adorava fazer piada à custa dos outros."1 Pelo vocábulo zonzo caracteriza-se a ingenuidade do menino que, ligado ao uso reiterado da expressão "sei não”, por ele empregada, tornou-se conhecido pela designação de "Seinão"2.

A princesa, aproveitando-se da falta de malícia de Seinão,

\footnotetext{
${ }^{1}$ LAGO, Angela. Indo Não Sei Aonde Buscar Não Sei O Quê. Belo Horizonte, RHJ, 2000, p.1.

${ }^{2}$ Em depoimento a esta pesquisadora em fevereiro de 2001, em São Paulo, Angela Lago salienta que a proposta inicial de se elaborar um trabalho que contivesse aspectos referentes à oralidade, associado a elementos do imaginário medieval e tangenciado pela ludicidade, surgiu após um comentário ouvido por acaso: É tão distraído que se mandarem ele ir à não sei onde, ele vai.
} 
propõe-lhe, jocosamente, casamento, como forma de recompensa pela tarefa a ele designada. A personagem é então submetida a uma prova - ir não sei onde e trazer-lhe não sei o quê. Seinão, caracterizado como o bobo da corte, que naturalmente se expõe e é motivo de zombaria, aceita a incumbência e sai disposto a cumpri-la. Dentro do universo da personagem, a crença na conquista do respeito e do amor da princesa é tal que ele parte em busca de algo inexistente, visando à satisfação de um desejo.

Seinão é, na esfera da ação do herói, segundo os estudos de Propp, aquele que deixa o lugar de origem, envolvido numa aventura marcada pelas provas difíceis que precisa superar. A tarefa de Seinão relaciona-se à conquista do objeto mágico, que não precisa, dentro da narrativa, especificamente, ser considerado mágico. O objeto deve, no entanto, ser portador de um caráter misterioso. Esse caso, aplica-se a Seinão, pois o conteúdo do objeto que lhe destinaram conseguir jamais foi revelado “ninguém neste mundo sabe o que tem um embrulho do diabo ..”. 3 , salienta o narrador. Entre os ditos populares, há um que atribui ao diabo a conotação de “tramóia”, “coisa mal feita.” Se inserirmos tal consideração dentro do texto, então o embrulho pode conter inúmeras surpresas ou revelações e, na narrativa tornar-se o responsável direto pela sorte do herói, que alcança a realização plena - o amor e o respeito da princesa.

O povo, encarnando um dos antagonistas de Seinão, tenta ludibriá-lo quando é questionado a respeito da "estrada para ir a não sei onde.(...) Pois se perguntava o caminho - a estrada para ir a não sei onde caíam na risada ou mandavam ele ir para o inferno.”“ Disposto em uma das páginas, está o traçado de figuras que se assemelham aos tipos populares

\footnotetext{
${ }^{3}$ LAGO, Angela. Indo Não Sei Aonde Buscar Não Sei O Quê. p.23.

${ }^{4}$ Idem, ibidem, p.6.
} 
encontrados nos contos dessa natureza, apontando para Seinão. Ocultando com as mãos o riso de zombaria, os representantes do povo divertem-se da ingenuidade da personagem, conforme podemos observar na prancha número 1.

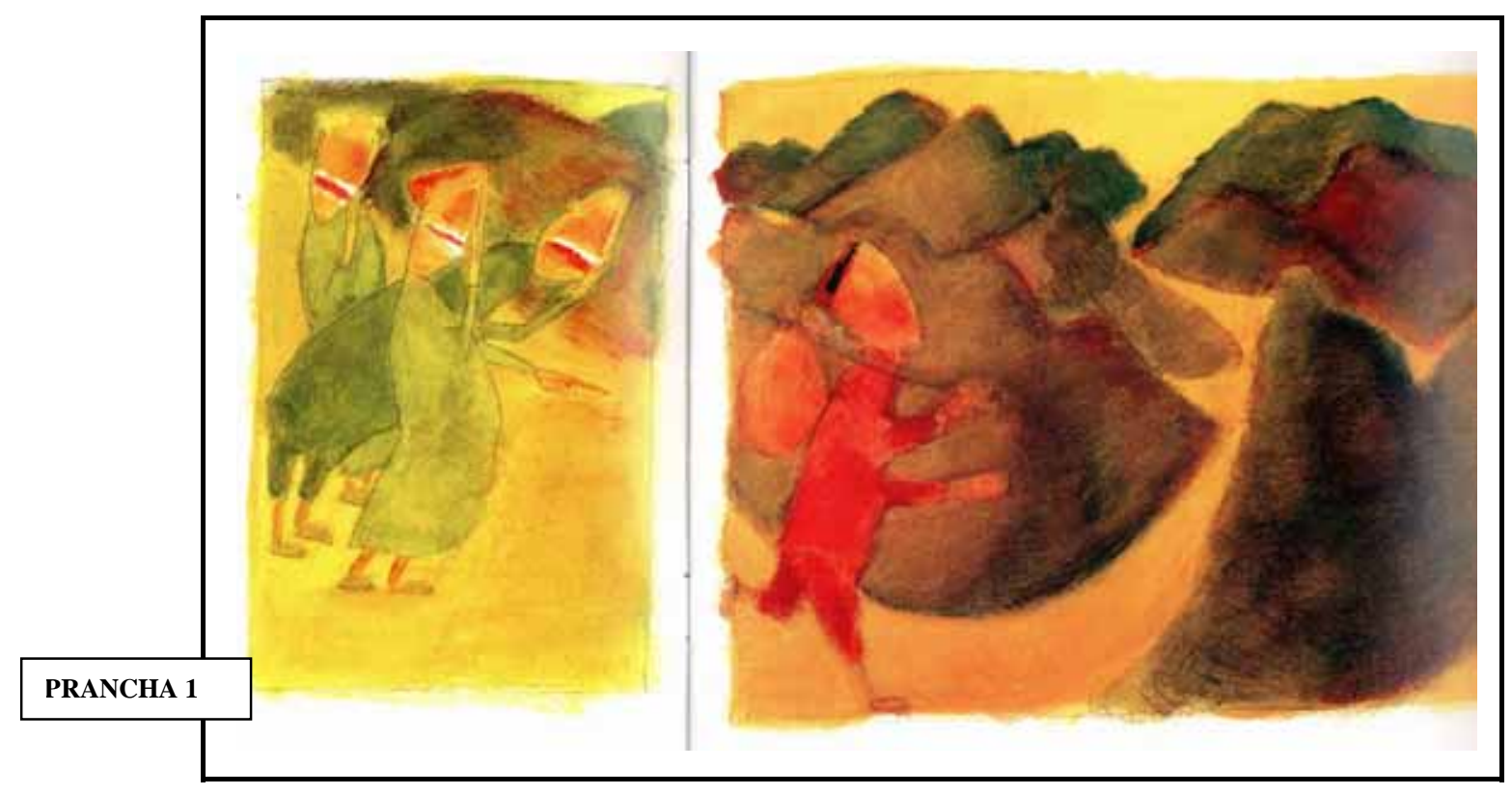

Mas, a Corte e o povo, inicialmente opositores do protagonista, também atuam como personagens coadjuvantes quando, pela espontaneidade, auxiliam Seinão no seu encontro com o Diabo e no posterior desfecho feliz da estória.

\subsection{Nas trilhas da cultura medieval}

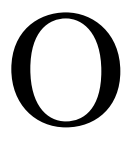

riso, mais especificamente, o riso que poderia representar zombaria, na narrativa, está ligado à mentalidade do homem medieval, que atribuía ao riso “... um profundo valor de concepção do mundo (...) uma das formas capitais pelas quais se exprime a verdade sobre o mundo na sua 
totalidade, sobre a história, sobre o homem ..."5 Compreende-se, a partir da citação, que o conceito de riso, na Idade Média, está inserido dentro do universo do extremamente importante, marcado pelo princípio bipolar da degradação e regeneração, embora a insistente posição do Feudo-Clericalismo, da época, em atribuir ao cômico a extra oficialidade, reservando às verdades consideradas primordiais os tons sérios. Ensina-nos Bakhtin que “... o tom sério afirmou-se como a única forma que permitia expressar a verdade, o bem, e de maneira geral tudo que era importante (...). O medo, a veneração, a docilidade, etc., constituíam por sua vez os tons e matizes dessa seriedade.”6 É, igualmente, de Bakhtin a afirmativa que esclarece o teor representativo do riso na Idade Média:

"A riquíssima cultura popular do riso na Idade Média viveu e desenvolveu-se fora da esfera oficial da ideologia e da literatura elevada. E foi graças a essa existência extra-oficial que a cultura do riso se distinguiu por seu radicalismo e sua liberdade excepcionais, por sua implacável lucidez. Ao proibir que o riso tivesse acesso a qualquer domínio oficial da vida e das idéias, a Idade Média lhe conferiu em compensação privilégios excepcionais de licença e impunidade fora desses limites: na praça pública, durante as festas (...). E o riso medieval beneficiou-se com isso ampla e profundamente." ${ }^{7}$

$\mathrm{O}$ ato de rir neste conto não assume, portanto, um caráter destrutivo. O povo ri do herói, porque a designação que recebe e sua pronta

\footnotetext{
${ }^{5}$ BAKHTIN, Mikhail. A Cultura Popular na Idade Média e no Renascimento. Trad. Yara Frateschi. 4.ed. São Paulo-Brasília, Hucitec, 1999, p.57.

${ }^{6}$ Idem, ibidem, p.63.

${ }^{7}$ BAKHTIN, Mikhail. op. cit., p.62.
} 
aceitação é, de fato, naquele momento narrativo, hilária. A postura jocosa das

personagens, diante do comportamento ingênuo de Seinão, que não percebe sequer a zombaria que lhe destinam, obstinado em cumprir a tarefa de receber o prêmio, confirma o clima de liberdade e espontaneidade que caracterizava eventos populares típicos da Idade Média. Seinão é o herói; os populares, o público, que ri, emociona-se, chora, dependendo do que assiste. Por outro lado, o riso, a zombaria popular dispensados a Seinão, dentro da construção narrativa, só vem reforçar, no final, o valor da vitória. O herói é escarnecido quando aceita o desafio. A extensão do descrédito que recebe está proporcionalmente associada à extensão da aclamação final. Obstinado, então, pela tarefa, Seinão não percebe a brincadeira e ignora a postura jocosa das personagens.

\subsection{Brincando de imaginar}

$\mathcal{Q}$ e corpo mirrado, a personagem percorre, no seu trajeto solitário, caminhos que poderiam expressar, segundo a disposição de linhas, e o emprego reiterado da tonalidade vermelha, aridez e sinuosidade. Em momento algum menciona-se a distância que a personagem tenha percorrido até chegar aos domínios do demônio, considerando-se o conceito popular atribuído ao inferno: "um fogo eterno localizado nas profundezas da terra.” A narrativa apenas sinaliza que o aventureiro “... de tanto andar e andar.”, chega ao inferno, porque também “... a estrada acabava ali ...”9, aspecto que poderia levar o leitor a concluir tratar-se de um longo percurso chegando até mesmo ao fim do mundo, não restando à personagem outra opção a não ser aceitar a

\footnotetext{
${ }^{8}$ LAGO, Angela. Indo Não Sei A Onde Buscar Não Sei O Quê. p.8.

${ }^{9}$ Idem, ibidem, p.10.
} 
hospitalidade do capeta. Note-se que o comportamento do demônio exprime uma infração. A aceitação passiva de Seinão ao inferno e o tom irônico empregado ao concordar com a personagem que o inferno era não sei onde, denota uma reação às avessas. O leitor então, instigado por essa inversão de dados é conduzido, de maneira lúdica, a outros questionamentos ${ }^{10}$, cujas respostas ele não encontra porque está na intencionalidade do narrador deixálas em suspense.

\subsection{Dos meandros do conto popular ao sabor da expectativa às avessas.}

$\prod$ o conto, enquanto gênero, a ação ocorre geralmente “... num país distante, longe, muito longe daqui, passa-se há muito, muito tempo, ou então o lugar é em toda e nenhuma parte, a época sempre e nunca.”11

A ação se passa, parcialmente dentro de um certo castelo e nas dependências do inferno. Nesse tempo de aventuras, assinalam-se momentos, “hiatos extratemporais”"12 que correspondem à organização do enredo. Assim o texto informa, como referencial de tempo que “... durante dias, a diversão do palácio foi caçoar do bobo ...”13 e que o diabo, numa bela tarde “... acordou com saudades das novidades de sua seção."14; enfim, situações, dados que não contribuem em nada para a vida do herói. Ainda que o conto não aluda à ciclicidade como fator de retratação do cotidiano, tais fragmentos expressam linearidade na relação entre a causa, o motivo que anima a efabulação Seinão vai ao palácio e revela sua paixão à princesa - e a conseqüência trazida

\footnotetext{
${ }^{10}$ Em conversa com uma leitora de oito anos de idade, a respeito da obra, esta me indagou sobre uma questão de ordem espacial: Se a terra é redonda, onde fica o fim do mundo? E o inferno?

${ }^{11}$ JOLLES, André. Formas Simples. Trad. Álvaro Cabral. São Paulo, Cultrix, 1976, p. 202.

${ }^{12}$ BAKHTIN, Mikhail. Questões de Literatura e de Estética. Trad. Aurora F. Bernadini. 4.ed. São Paulo, Unesp, 1998, p. 216.

${ }^{13}$ LAGO, Angela. Indo Não Sei Aonde Buscar Não Sei O Quê. p.5.

${ }^{14}$ idem, ibidem, p.16.
} 
pela causa - o desafio, a conclusão da tarefa e o final feliz..

Inserida dentro do tempo mítico ${ }^{15}$, a narrativa não assinala quando a estória tem seu início, a época da partida de Seinão e nem tão pouco alude ao tempo de duração da viagem. Sabe-se que “ era uma vez um menino...”16 Salienta Bakhtin que a ruptura extratemporal, na qual está construído o conto, isenta-se tanto do tempo biográfico que corresponde ao aspecto cíclico quanto da vida biográfica das personagens - o herói continua alimentando os mesmos objetivos. Como o tempo não é cronológico, as personagens não sofrem o desgaste do tempo, não perdem a jovialidade.

O deslocamento espacial da personagem - O “zonzo do Seinão acreditou [nas palavras da princesa] e foi!”17 ocorre a partir do palácio a "não sei onde”, onde tudo

“... é indeterminado, desconhecido, alheio; os heróis estão ali pela primeira vez, eles não têm quaisquer relações ou ligações substanciais com esse mundo, (...) por isso, para eles existem nesse mundo apenas coincidências e não coincidências fortuitas.”18

O encontro inicial de Seinão com a princesa, que sela o pacto entre ambos, vai estreitar-se com o cronotopo da estrada, o caminho, onde o herói tem um encontro inesperado com o capeta. O herói, cujos traços de "privatividade e isolacionismo" ${ }^{19}$ remetem ao homem característico do romance grego, será conduzido pela coincidência casual, como agente passivo

\footnotetext{
${ }^{15}$ O tempo mítico é “... o tempo imutável, eterno, que se repete sempre igual, sem evolução nem desgaste ...” segundo Nelly Novaes Coelho em A Literatura Infantil. 4.ed. São Paulo, Quíron, 1987, p.55.

${ }^{16}$ LAGO, Angela. Indo Não Sei Aonde Buscar Não Sei O Quê. p.1.

${ }^{17}$ Idem, ibidem, p.5.

${ }^{18}$ BAKHTIN, Mikhail. Questões de Literatura e de Estética. p.225.

${ }^{19}$ Idem, ibidem, p.231.
} 
da ação, “... o verdadeiro homem de aventuras é o homem do acaso; como homem com quem aconteceu algo, ele ingressa no tempo de aventuras. Pois a iniciativa nesse tempo não pertence às pessoas.”20 Guiado pela força do destino, a personagem, então, ingressa na esfera das oportunidades e da ascensão.

No conto popular, o trajeto, a viagem, de acordo com Chevalier podem ser interpretadas como:

\begin{abstract}
“ ... um desejo profundo de mudança interior, uma necessidade de experiências novas, mais do que de um deslocamento físico. Segundo Jung, indica uma insatisfação que leva à busca e à descoberta de novos horizontes (...). A viagem ao inferno representa uma descida às origens (...) uma descida ao inconsciente, de acordo com as interpretações modernas (...). A viagem aos infernos parece ser geralmente sentida mais como uma autodefesa, uma autojustificação, do que uma autopunição.”21
\end{abstract}

Pela afirmação do teórico, deduz-se que a personagem precisava chegar às últimas conseqüências em favor de novas experiências e provar que era capaz. Neste particular, Huizinga esclarece que:

“... tanto o conflito quanto o amor implicam rivalidade ou competição, e competição implica jogo. Na grande maioria dos casos, o tema central da poesia e da literatura é a luta isto é, a tarefa que o herói precisa cumprir, as provações por que ele tem que passar, os obstáculos que ele precisa

\footnotetext{
${ }^{20}$ BAKHTIN, Mikhail. Questões de Literatura e de Estética. p.220.

${ }^{21}$ CHEVALIER, Jean; GHEERBRANT, Alain. Dicionário de Símbolos. Coord. Carlos Sussekind. Rio de Janeiro, José Olympio, 1988, p.952.
} 
transpor. Já é suficientemente esclarecedor o uso da palavra 'herói’ para designar o personagem principal. A tarefa será extraordinariamente difícil, aparentemente impossível. Em geral, ela é empreendida em conseqüência de um desafio, de uma promessa ou de um capricho da pessoa amada., ${ }^{22}$

Elucidamos, contudo, a presença, mais uma vez, do fio parodístico que delineia a performance de Seinão. Na condição de tolo, a personagem não possui habilidade para analisar o pedido da princesa. Na aventura empreendida, a casualidade o fez chegar ao inferno, denominado, ironicamente, pelo demônio de "não sei onde.” A obtenção de "não sei o quê" também é acidental, logo, Seinão é herói às avessas.

A inclusão, no texto verbal, de vocábulos tais como "pasta", “arquivo”, “atualização”, termos comuns à linguagem da Informática, está em desacordo com o contexto espaço-temporal medieval em que se passa a estória. Trata-se então, de uma articulação da autora que procura, descontraidamente, entremear elementos pertinentes a dois momentos históricos distintos: a era tecnológica, como canal veiculador de informação e, num recuo no tempo, a incorporação da figura do demônio à estrutura narrativa. Este registro do tempo - a atualidade em fusão com o medieval cria, na mente do leitor, uma possível associação entre a Informática e o inferno gerando um tom de humor, uma vez que o capeta, moldado aos padrões da modernidade, utiliza-se dos meios tecnológicos para arquivar os males do mundo.

\footnotetext{
${ }^{22}$ HUIZINGA, Johan. Homo Ludens. Trad. João P. Monteiro. 4.ed. São Paulo, Perspectiva, 1996, p.148.
} 
De acordo com a prancha número 2, a ilustração, neste segmento, insinua a forma do diabo manuseando o computador, entretido que está na sua tarefa.

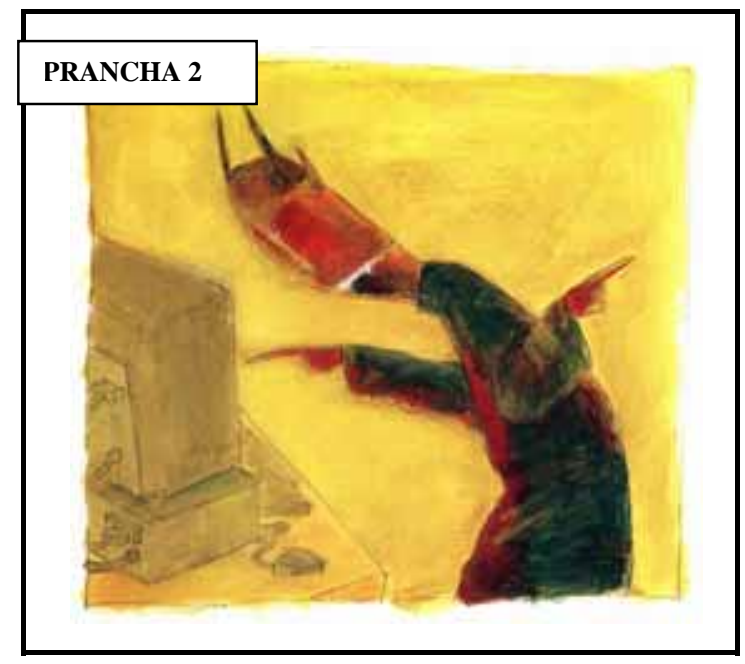

O motivo principal da efabulação - o desafio e a proposta de casamento ao protagonista, é antecipadamente revelado ao leitor, visando despertar-lhe o interesse pelo desfecho da estória. Coelho define a “antecipação” como:

“... Recurso pelo qual o narrador antecipa já no início o desenlace do drama ou do conflito em questão. O que aconteceu? é logo revelado ao leitor, e este, com a curiosidade espicaçada, se dispõe à leitura para descobrir como e porque aquilo aconteceu. 23

O segmento que registra o encontro amistoso entre a personagem e o diabo apresenta dados de inversão. Texto e ilustração descaracterizam a idéia de medo e terror que a figura do diabo poderia desencadear, a despeito de estar caracterizado com cascos, rabo e chifres. O local de sua habitação, por onde ele transita, durante a narrativa, também é apresentado sem

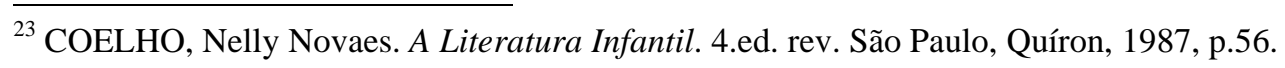


caracterização tradicional de provocar medo. Entretanto, a habilidade de manipular do representante do inferno se manifesta e, afinal, contribui para a sorte de Seinão: “... Não sei onde é aqui. Pelo menos para você - enrolou um capeta que estava precisando de ajudante."24

De acordo com a classificatória das funções de Propp, o diabo será, na narrativa, o doador, aquele que vai, sem perceber, auxiliar a personagem a realizar o seu intento. O diabo pensando estar tirando vantagens de Seinão, que aceita o serviço proposto - atualizar os arquivos de pecados passa a ser enganado, “embrulhado” pela personagem que vai cometer algum erro nos registros do inferno, em algum momento da digitação, conforme se constata claramente na seqüência narrativa.

O retorno ao palácio, de posse do embrulho, significa para a personagem a aceitação pelo grupo social, aprovado pela Corte, não mais como o “... bobo que tinha ido atrás do impossível.,"25

\subsection{O visual e a estória}

1 etonimicamente, a ilustração assegura a função narrativa. Em segmentos como o que ilustra a zombaria dos membros da corte, (vide prancha número 3), observam-se rostos de risos escrachados, apontando com o dedo indicador em direção ao aldeão.

\footnotetext{
${ }^{24}$ LAGO, Angela. Indo Não Sei Aonde Buscar Não Sei O Quê. p.10.

${ }^{25}$ Idem, ibidem, p.6.
} 


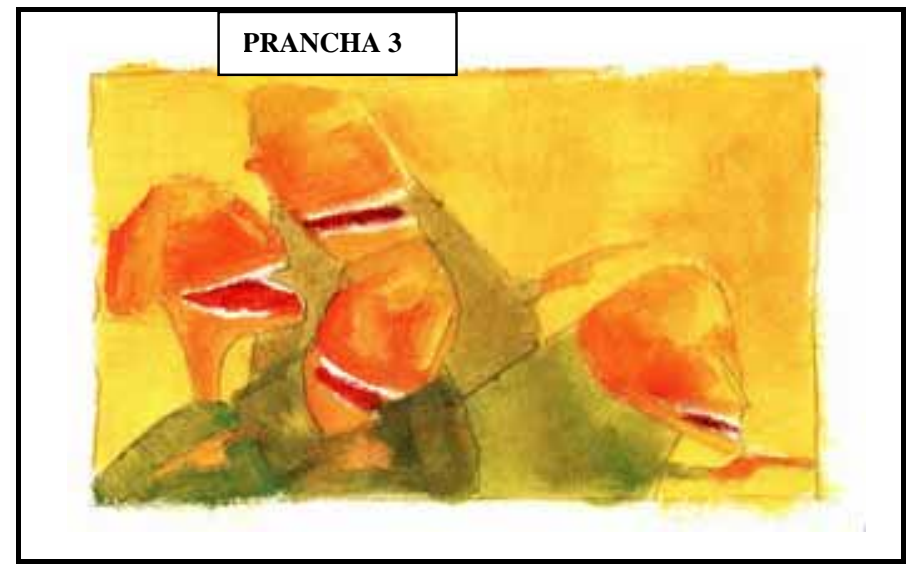

As composições, trabalhadas na tonalidade vermelha, estariam relacionadas à indumentária do rei, e do próprio capeta se considerarmos a proposta de Kandisnky ${ }^{26}$ sobre a linguagem e a ação das cores sobre o observador. Poderíamos ainda, de acordo com o pensamento medieval, associar a cor vermelha ao conceito popular de inferno - local escuro onde estariam os pecadores sentenciados respondendo, através do “fogo eterno”, às suas faltas. O amarelo e o verde corresponderiam à movimentação dos cenários que retratam aldeias e descampados. As três tonalidades: vermelha, amarela e verde, devido à sua forte intensidade, aproximariam o olhar do leitor à cena, numa tentativa de resgatar a estória, ocorrida em um tempo distante.

Os desenhos, apresentando cores sobrepostas, não excluem a particularidade de cada traço. O seu pseudo-despojamento - contorno pouco definido, apresentando-se rasgado, rabiscado, desvela uma proposta da autora - a de estar “... experimentando e brincando com tintas e pincéis feito criança." ${ }^{27}$ Angela Lago resgata na obra, em nível de ilustração, esta característica da criança - o rompimento de padrões pré-estabelecidos, a flexibilidade e a liberdade no momento de criar.

\footnotetext{
${ }^{26}$ Sobre o conceito das cores e suas influências no comportamento do homem, consultar KANDINSKY, Wassaly em O Espiritual na Arte. Trad. Álvaro Cabral; Antonio de P. Danesi. São Paulo, Martins Fontes, 1996.
} 
A obra que trabalha cores fortes e contrastantes, alude ao Fauvismo $^{28}$. O papel de superfície lisa e acetinada comporta certa luminosidade. A textura conseguida no desenho é obtida pelas várias intervenções sobre a tinta já trabalhada. A ilustração é, então, o resultado da reprodução conjunta de cores, em grandes pranchas, que se dividem em folhas duplas - um procedimento que visa não somente a um melhor aproveitamento do papel, mas à harmonização dos desenhos, devido à sua disposição ampliada.

A obtenção de luminosidade nos quadros se faz por meio da utilização de cores claras em contraste com as escuras. $\mathrm{O}$ amarelo que se contrapõe ao vermelho, no segmento que descreve a chegada de Seinão ao inferno, conforme prancha número 4, delineia o espaço reservado ao entreabrir da porta, mostra o interior iluminado de um ambiente e aproxima os olhos do leitor que tenta captar detalhes ocultos pela porta.

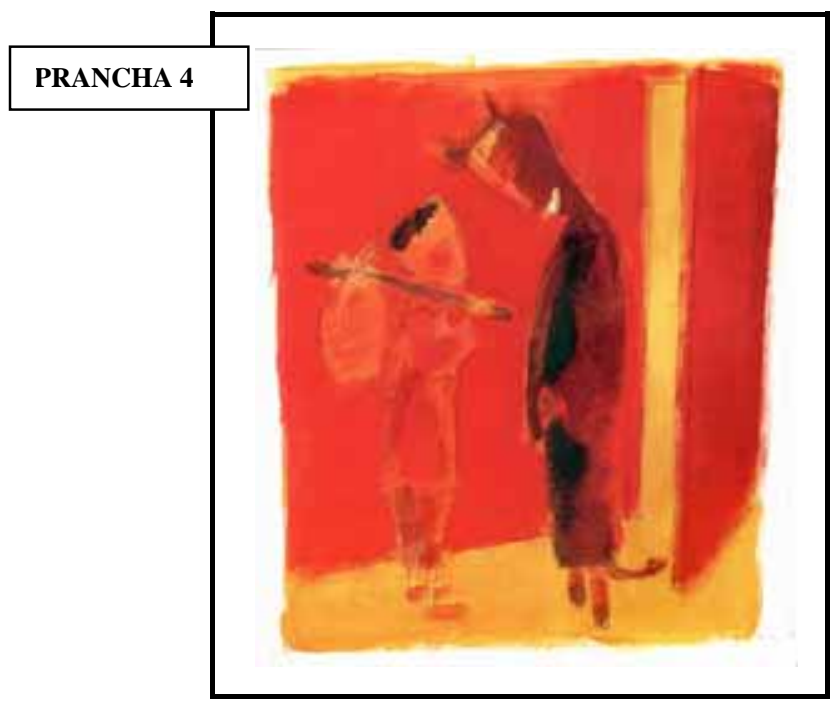

\footnotetext{
${ }^{27}$ Informação obtida em entrevista com Angela Lago, em março de 2001 em São Paulo.

${ }^{28}$ Fauvismo - "primeiro movimento revolucionário do século XX, em que os pintores fizeram da tela um plano, empregando tonalidades explosivas e contrastantes. Para isso eles restringiram ao mínimo uso das cores que dão a sensação de profundidade, ou seja, as cores frias, que são o verde, o azul e o violeta. A Arte de Pintar. Círculo do Livro. São Paulo, Nova Cultural, 1994, p.80.
} 
Na representação pictórica da chegada da personagem ao castelo, trazendo o pacote, o amarelo mais uma vez será responsável pelo efeito claro e escuro, quando demarca os cabelos louros da princesa, que se destacam do fundo vermelho de uma provável parede do castelo, conforme prancha número 5.

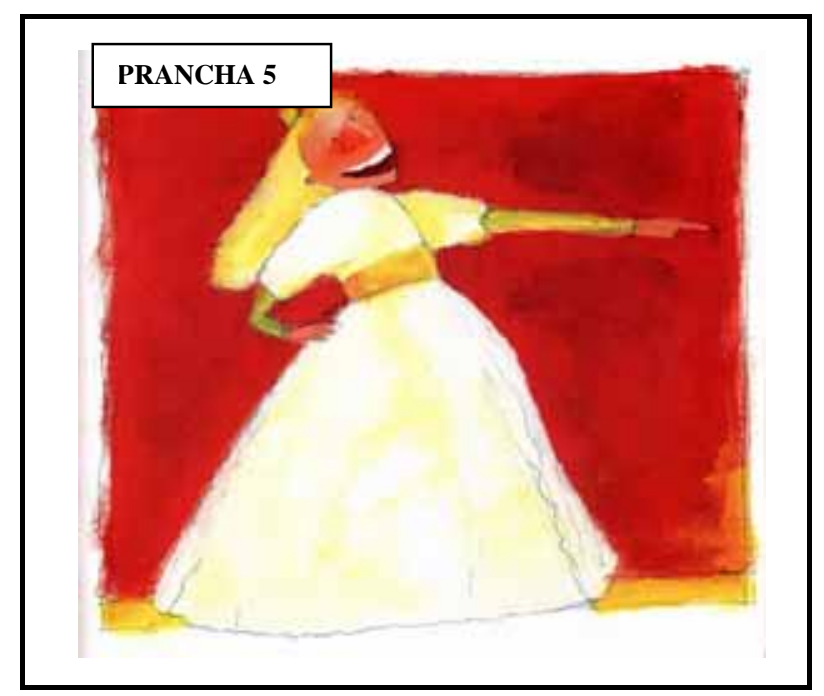

As duas tonalidades, consideradas quentes, estabelecem proximidade entre as personagens. Dispostas no corte da página estão Seinão e a princesa. Com o manuseio do livro, no ato de abrir e fechar da página, o movimento insinua o deslocamento das personagens, aproximando-se.

A reiteração da tonalidade branca, igualmente ressalta a linha que delimita a boca, de dimensões desproporcionais, das personagens, consolidando a função expressiva da ilustração, alicerçadas, como vimos, nas cores vermelha, amarela e verde.

A conexão dos vários componentes da composição dá-se pelo recurso da aproximação, fator que possibilita a visualização de um conjunto consonante de leituras e cores. $^{29}$ William ainda argumenta sobre a

\footnotetext{
${ }^{29}$ WILLIAMS Robin. Design para quem não é designer . Trad. Laura K. Gillon. São Paulo, Callis, 1995, p.21 argumenta que o agrupamento de componentes relacionados em proximidade ou dispostos em
} 
arbitrariedade dos elementos na página - disponibilizar os componentes em uma cena sem atribuir-lhes uma função específica. Cada item precisa ser alinhado de modo a criar uma unidade lógica, facilmente identificada pelo observador. Entretanto, o que se vê em Indo Não Sei Aonde Buscar Não Sei O Quê é um despojamento do desenho, uma despreocupação intencional com alinhamentos, molduras, contornos ou disposições planejadas dos componentes na cena, evidenciando um esmaecimento que poderia remeter o conto a um lapso espaço-temporal indefinido; a preservação seqüencial da ação, fica, então, a critério do texto verbal que orienta o leitor para as várias etapas da narrativa.

As unidades composicionais, em contigüidade, encaminham a leitura de um lugar para outro, obedecendo a uma seqüência cronológica. Esse recurso permite ao leitor, por sua vez, sentir nas personagens a movimentação, como se houvesse uma simbiose entre o espaço, onde se localiza a cena e o tempo real, aquele destinado à leitura.

Quanto à disposição das linhas, as agrupadas sugerem tensão entre si, à medida que requerem e oferecem apoio mútuo no quadro que mostra a descrição da personagem, em meio à sua viagem.

afastamento, além de estruturar as informações do texto, forma uma unidade visual, “...um conjunto coeso e não um emaranhado de partes sem ligação.” 
Do lado direito da mesma página, a curvatura da linha insinua a estrada sinuosa que Seinão terá que percorrer, como demonstram as pranchas números $6 \mathrm{~A}$ e $6 \mathrm{~B}$.
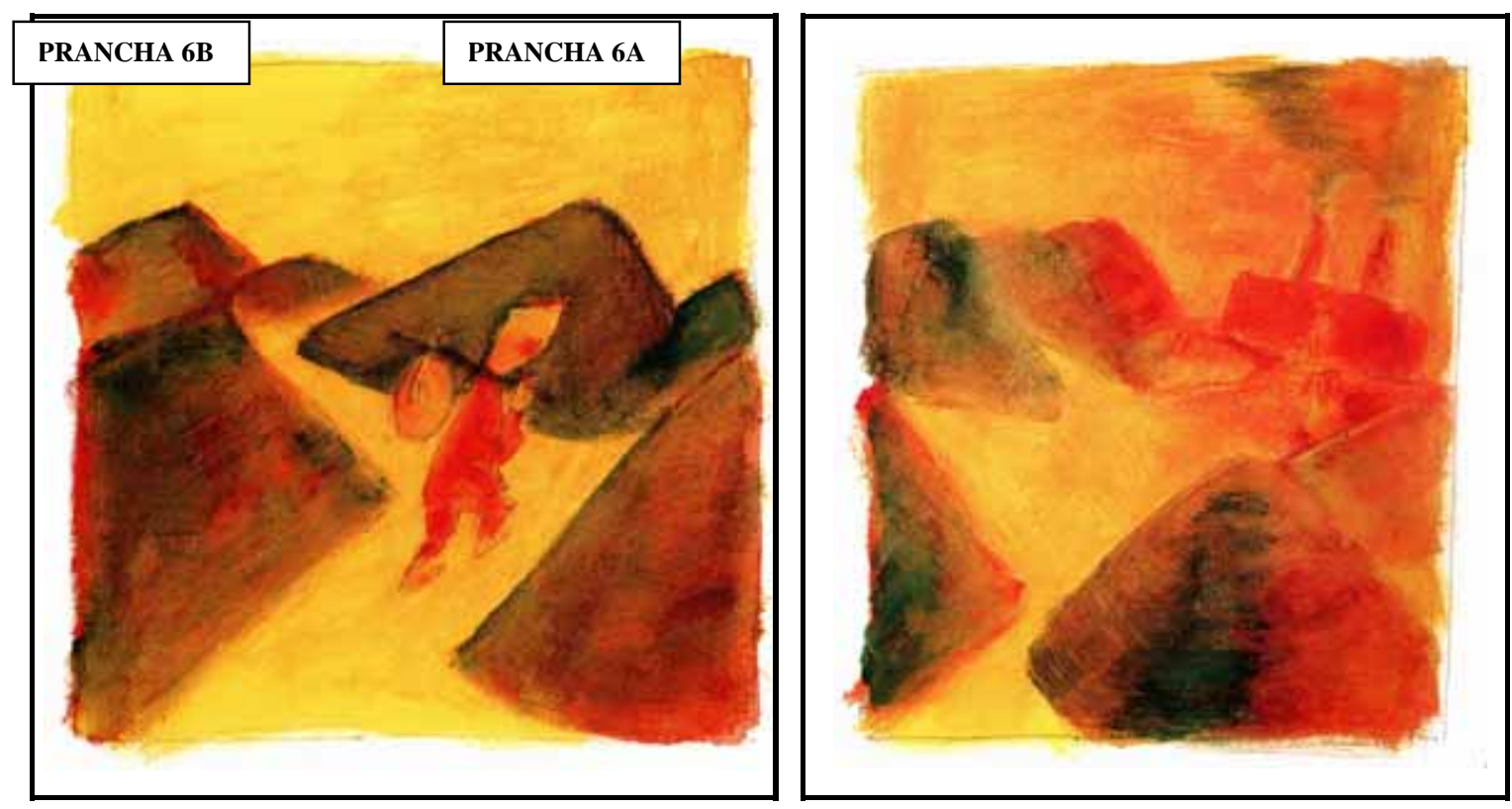

Em algumas seqüências, a composição possui mais de um elemento em destaque. A performance da personagem protagonista não subtrai dos quadros detalhes como a despreocupação da princesa com a sorte do rapaz, a tranqüilidade exagerada do diabo e principalmente a expressão de surpresa da nobreza quando do retorno de Seinão. O texto verbal reafirma este aspecto, através de expressões tais como: “- Impossível... - retrucou a princesa sabida e Seinão deu tempo para a princesa e os sábios do palácio pensarem à vontade. Não havia dúvida: A encomenda estava certa.”30

\footnotetext{
${ }^{30}$ LAGO, Angela. Indo Não Sei Aonde Buscar Não Sei O Quê. p.21.
} 


\subsection{Final feliz?}

$\mathrm{P}_{\text {odemos igualmente observar que, agregado aos caracteres que }}$ remetem à cultura oral, estão, no segmento que retrata o retorno do herói ao castelo, “... cantando de alegria ...”31, traços de folclore:

“ - Ô princesa me responde

Quando eu caso com você.

Eu já fui a não sei onde.

Já busquei não sei o quê.,"32

A alegria e o riso espontâneos, trazidos pela tradição oral, pelo contar e recontar da estória, interligam-se com o modo simples de ser, principalmente, da criança que introjeta a proposta como mais uma brincadeira - o de fazer o outro de bobo, semelhante a qualquer outra que faz parte de seu mundo povoado de sonhos. Na esfera do verbal, a coloquialidade evidencia, além do comportamento do homem simples, o comportamento infantil: ${ }^{33}$ "E resolveu ... Bem, antes que o diabo descobrisse que ele também tinha aprontado uma embrulhada com os tais arquivos ... pernas para que te quero!”34 Vale tudo na brincadeira quando o assunto é "pregar uma peça.”

O final feliz, que culmina com o casamento entre Seinão e a princesa, consiste em mais um dos aspectos relativos ao riso. A idéia de que

\footnotetext{
${ }^{31}$ LAGO, Angela. Indo Não Sei Aonde Buscar Não Sei O Quê. p.20.

${ }^{32}$ Idem, ibidem, p.19.

${ }^{33}$ COELHO, Nelly N. em A Literatura Infantil. 4.ed. rev. São Paulo, Quíron, 1987, p.20, salienta que, tanto no popular quanto no infantil, “... o conhecimento da realidade se dá através do sensível, do emotivo, da intuição... e não, através do racional ou da inteligência intelectiva, como acontece com a mente adulta e culta. Em ambos predomina o pensamento mágico, com sua lógica própria.”

${ }^{34}$ LAGO, Angela, loc. cit.
} 
tudo está bem, que a ordem e o equilíbrio foram novamente resgatados, faz parte da uma visão cosmogônica e mítica do homem medievo-moderno. Para Seinão houve, após o cumprimento da tarefa, a recompensa, a concretização de seu desejo. A personagem deixa transparecer que está feliz por ter cumprido a tarefa; não demonstra que ter ido ao inferno, conversado com o diabo, manuseado arquivos de tal porte, como o que alistava os pecados dos homens, tenha tido importância maior no seu destino do que se casar com a princesa. Em outro nível de leitura, o final feliz pode nos remeter à preservação do imaginário medieval através dos mitos, dos ritos, do contar, do improvisar. E ainda, na manutenção dos grandes mistérios, que povoam o espírito popular medieval, aguçando a eterna curiosidade do homem, haja vista continuar velado o "segredo" contido no embrulho vindo do inferno. Além disso, a figura representativa de Seinão alimentaria a crença na renovação permanente e na constante reparação do mal e da injustiça, fatores que levam o homem a acreditar no final feliz, apaziguado e conveniente a todos.

Dentro deste mesmo contexto, podemos atentar para outro traço parodístico da obra, quanto ao final feliz. Sobre a intencionalidade da princesa com relação a Seinão, em momento algum fica evidente no texto, a não ser quando menciona seu desejo de “... fazer piada à custa dos outros.”35 Então, diante da realização da tarefa pelo herói, a princesa estaria obrigada a casar-se com ele, apenas como cumprimento de regras de um jogo, por ela mesma estabelecidas.

\footnotetext{
${ }^{35}$ LAGO, Angela. Indo Não Sei A Onde Buscar Não Sei O Quê. p.2.
} 
Mas, o aventureiro, a princípio o bobo da Corte, ao demostrar perspicácia e sabedoria, consegue conquistar o amor da princesa - aspecto sinalizado pelos signos verbal e visual através da sentença: "Pois é: Seinão está muito bem casado e o embrulho segue embrulhado!”36 ( vide prancha número 7).

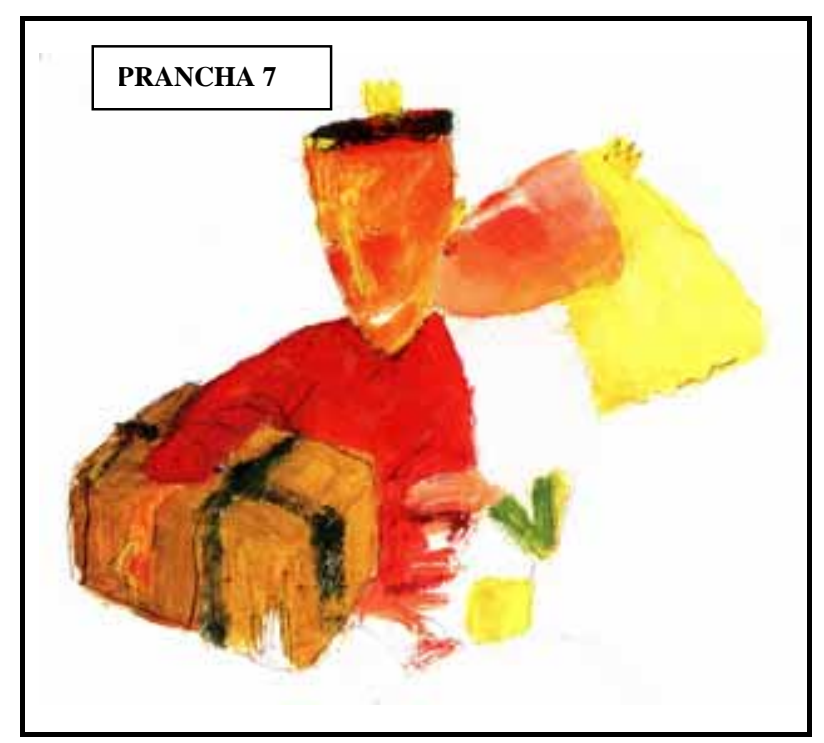

${ }^{36}$ Idem, ibidem, p.24. 
Relação de Pranchas referentes ao capítulo 4.

$\begin{array}{ll}\text { Prancha 1 } & \text { p.121 } \\ \text { Prancha 2 } & \text { p.128 } \\ \text { Prancha 3 } & \text { p.130 } \\ \text { Prancha 4 } & \text { p.131 } \\ \text { Prancha 5 } & \text { p.132 } \\ \text { Prancha 6A } & \text { p.134 } \\ \text { Prancha 6B } & \text { p.134 } \\ \text { Prancha 7 } & \text { p.137 }\end{array}$


“O riso é tão universal como a seriedade.”

Mikhail Bakhtin

$\prod$ o decorrer deste trabalho evidenciamos a presença de traços de oralidade e cultura popular - resgatados na Idade Média - nas obras contemporâneas de Angela Lago, tendo como motivos centrais, o estudo da adivinha, em Sua Alteza A Divinha e em 10 Adivinhas Picantes; o estudo da charada, em Charadas Macabras, os estudos dos elementos alicerçados na prática do jogo, do riso, da comicidade em Indo Não Sei Aonde Buscar Não Sei O Quê.

Nas obras analisadas, o riso mescla-se à seriedade no tratamento de temas tais como os da vida e da morte e do enfrentamento do desconhecido inseridas no imaginário medieval, dentre outros. O que se pretende colocar em evidência, é o modo despojado com que o narrador constrói o recurso parodístico, fazendo interagir os códigos verbal e visual.

Em Indo Não Sei Aonde Buscar Não Sei o Quê a presença da expectativa às avessas é mais acentuada. Um dos aspectos em pauta é a questão da relação amistosa entre o Capeta e Seinão, quando se poderia qualificar de aterrorizante o momento do encontro entre ambos. 
Trazer para o castelo um embrulho contendo não sei o quê é outro disparate principalmente porque ele “... segue bem embrulhado.”1 A Seinão é recomendada a não abertura do embrulho “... pois se abrir deixa de ser.” 2 Por outro lado, o diabo, de postura dominadora e riso sarcástico, é ludibriado por Seinão que age de má fé com os arquivos do capeta. Dentro da tradição oral há um ditado que bem clarifica este raciocínio: “O feitiço virou-se contra o feiticeiro.”

Sua Alteza Adivinha sustenta, igualmente, um desfecho contrário ao esperado. O narrador, pela conduta da narrativa, cria uma perspectiva de derrota ao aldeão que sonhava pertencer à nobreza. O sucesso, entretanto, provou originalidade e desenvoltura da personagem.

A ausência do terror "impactante" entre o leitor-personagem e o capeta, e o modo descontraído com que o narrador conduz a estória, são fatores que provocam o efeito paródico em Charadas Macabras.

Nas duas obras em que figura o demônio, as personagens são enganadas pelo homem, que se mostra mais versátil no trato com os problemas de difíceis soluções. Sobre este aspecto, Cascudo argumenta que “em todos os contos e disputas poéticas o Demônio intervindo, perde a aposta e é, infalivelmente, logrado.” ${ }^{3} \mathrm{O}$ folclorista ainda salienta:

“... A derrota do Demônio na novelística é quase universal. Nos contos populares brasileiros, portugueses, espanhóis, africanos, árabes, não conheço uma vitória do Demônio, em matéria de aposta, aceitando desafio ou firmando contratos."4

\footnotetext{
${ }^{1}$ LAGO, Angela. Indo Não Sei Aonde Buscar Não Sei O Quê. Belo Horizonte, RHJ, 2000, p.24.

${ }^{2}$ Idem, ibidem, p.17.

${ }^{3}$ CASCUDO, Luis da Camara. Literatura Oral no Brasil. 3.ed. Belo Horizonte, Itatiaia, 1984, p. 262.

${ }^{4}$ Idem, ibidem, p. 262.
} 
De modo geral, o riso que impulsiona a personagem a vencer o medo do capeta, prosseguir na sua performance, seja no palácio ou no tablado, é o mesmo que convida o leitor a continuar a leitura prazerosa, trazida pelo conto.

Em nível de intencionalidade das personagens, observamos que Louva-a-deus vai ao palácio movido pela idéia de competição. O leitorpersonagem e o capeta que chegam juntos ao cemitério, a princesa que propõe adivinhas e a outra que sugere a Seinão ir à procura de algo extraordinário, possuem inclinação pela arte de jogar. Mas o leitor, em especial, a criança, sabe que todo jogo implica em riscos, toda competição é bipolar. Participar de uma aposta significa seguir as regras do jogo.

A prática milenar do jogo - o jogo enigmático das palavras, o jogo do raciocínio lógico, o desafio, instigam e envolvem o leitor, principalmente a criança, que interage com texto e ilustração, memorizando os segmentos narrativos, repetindo-os após a conclusão da leitura, na forma de brincadeira ou aventurando-se em possíveis recriações em cima do texto apreendido, principalmente no que se refere à formulação de charadas - tomase uma palavra (a resposta da charada), atribui-se-lhe a cada sílaba um número e desmembra-a de modo que suas sílabas lidas separadamente assumam outra conotação; e de adivinhas - o interrogador lança uma pergunta, cuja resposta consegue-se pela associação de idéias, pela subtração de elementos contidos na pergunta.

Em Indo Não Sei Aonde Buscar Não Sei O Quê, a princesa desafia Seinão, que certamente não era o pretendente escolhido, mas a palavra empenhada no momento da provocação, obriga-a a cumprir a sua parte no 
acordo porque ela sabe, assim como a criança, que ganhar e perder fazem parte do jogo. ${ }^{5}$

Não se percebe na obra uma obrigatoriedade em se trazer o objeto solicitado como em Sua Alteza A Divinha, quando adivinhar é condição "sine qua non” para não se morrer. Se existe uma intencionalidade de punição, esta se refere a não concretização do casamento e conseqüentemente o não reconhecimento de Seinão como herói. Sair à procura de não sei o quê faz parte do seu processo de busca - busca pela princesa, pela felicidade, busca de concretização de sonhos.

A presença do tolo que se torna herói nas obras analisadas, aspecto, igualmente, observado nas cinco reeleituras da princesa hábil na formulação de adivinhações, elencadas no corpus do trabalho, difere de um para outro conto, quanto ao grau de ingenuidade das personagens. Independente do local da recolha e ou recriação, seja no Brasil ou em Portugal, as personagens popularmente denominadas de Amarelo, João, Louva-a-deus, Seinão, todos têm conhecimento sobre as vantagens que esse empreendimento - o de ir ao palácio tentar a sorte - pode trazer. Considerados pela nobreza, como candidatos bobos, intectualmente despreparados, esta não lhes confere credibilidade. $\mathrm{O}$ ato de vencer, entretanto, não implica somente em astúcia e obstinação, mas em conhecimento, em experiência no ato de jogar, improvisar, no riso espontâneo da praça pública, implica em sabedoria popular. E então, a nobreza curva-se para o homem simplório e o reverencia, trazendo para o palácio a cultura do povo.

\footnotetext{
${ }^{5}$ A brincadeira do "rei, capitão, soldado, ladrão", inclusa, implicitamente em Sua Alteza A Divinha, adequase, perfeitamente, na elucidação desse pensamento. Se, pelo contar dos dedos, o escolhido é rei ou capitão, a menina sente-se feliz, mas se o escolhido é o ladrão, há o desapontamento pelo resultado mas, em seguida, a aceitação porque isso faz parte das regras do jogo, além do que, tudo não passa de uma brincadeira.
} 
Resgatando características do medievalismo, Angela Lago então, equipara as personagens a loucos nas festas populares da Idade Média, que celebravam, extravasavam, carnavalizavam, visando o divertimento, a morte do antigo e a renovação da vida.

O verbal, alicerçado na cultura oral, traz, no exercício de desvendar charadas e adivinhas, o envolvimento do leitor através desse jogo de palavras que, por ser abrangente, seduz, abre caminhos, reverte situações, salva vidas... Inserido no texto estão vocábulos e expressões de uso popular que há muito tomam parte no imaginário medieval,( “cemitério”, “necrotério”, “inferno”, “castelo”, “Pernas para que te quero!”, “Ainda por cima quer me fazer de besta!”, “Ó deusa das horas eternas!”) e que a obra recupera de forma lúdica. Ensina-nos Goff que é na Idade Média que estão “... as nossas raízes, o nosso nascimento, a nossa infância (...). Uma Idade Média à qual ainda estamos ligados pelo fio, não cortado, da oralidade.”6

A ilustração, por sua vez, flagra elementos da cultura medieval e os insere na vida do homem moderno. Ora apropriando-se de desenhos que remetem à antiguidade, adaptando-os à linguagem digital, ora usando o pincel e a tinta, Angela Lago percorre mais de um caminho visando a manifestação estética e informativa do trabalho.

O suporte visual, não possui somente caráter complementar, limitando-se ao recontar da estória. De caráter informativo-lúdica, a ilustração amplia as possibilidades de leitura. Verbal e visual juntos não representam “... uma mera adição de duas mensagens informativas diferentes. Uma nova interpretação holística da mensagem total pode ser derivada dessa disposição."7

\footnotetext{
${ }^{6}$ GOFF, Jacques Le. O Imaginário Medieval. Trad. Manuel Ruas. Portugal, Estampa, 1994, p.41.

${ }^{7}$ SANTAELLA, Lucia; WINFRIED, Nöth. Imagem. Cognição, semiótica, mídia. São Paulo, Iluminuras, 1998, p.55.
} 
Desse modo podemos afirmar que a obra de Angela Lago representa para a Literatura, a expressão da arte, o estar, simultaneamente, em contato com variados atos comunicativos, seja verbal, visual, digital, gráfico, em constante recriação. Para a Literatura Infantil, sua obra tem contribuído para a divulgação das raízes populares, na qual está o homem alicerçado, principalmente ensinando para o leitor infantil como preservar, de maneira lúdica, essas lembranças. Angela Lago adentra ao universo infantil e ressalta a importância de ser criança, valorizando a sua expressão - seja através da manifestação pictórica - traçado, movimentos, cores, ou através da linguagem popular articulada, desprovida de rigores gramaticais, seja pela recuperação de brincadeiras que animaram, repetidas vezes, a infância de nossos antepassados, proporcionando, então, à criança a oportunidade de ser criança, de poder sonhar, fazer de conta, viajar para dentro de si mesma e imaginar-se num castelo, ser talvez a princesa e contar os ovos caídos na manta de Louvaa-deus e certificar-se de que são realmente sete ou sair à procura de não sei o quê, tentar desvendar o que há no embrulho do diabo, tremer de medo no necrotério, ensinar algumas charadas ao capeta e "morrer de rir"8 da cara do vigia. No fazer Arte com seriedade, Angela Lago ensina a arte de viver, brincando...

Argumentam Lowenfeld e Britain que:

“(...) podemos observar que a criança cria com a ajuda de qualquer grau de conhecimentos que possua nessa fase. O próprio ato de criar pode fornecer-lhe novos vislumbres, novas

\footnotetext{
${ }^{8}$ Morrer de rir - expressão popular muito usado dentro do vocabulário infantil.
} 
perspectivas e nova compreensão para a ação futura. Provavelmente, o melhor preparo para criar seja o próprio ato de criação.”9

${ }^{9}$ LOWENFELD, V.; BRITTAIN, W.L. Desenvolvimento da Capacidade Criadora. Trad. Álvaro Cabral. São Paulo, Mestre Jou, 1977, p.16. 
AZEVEDO, Ricardo J. Duff. Como o ar não tem cor, se o céu é azul? Vestígios dos Contos Populares na Literatura Infantil. Dissertação de Mestrado apresentada ao Departamento de Letras Clássicas e Vernáculas da Faculdade de Filosofia, Letras e Ciências Humanas da Universidade de São Paulo. São Paulo, FFLCH-USP, 1997.

BAKHTIN, Mikhail. A Cultura Popular na Idade Média. Trad. Yara Frateschi. 4.ed. São Paulo-Brasília, Edunb, 1999.

Questões de Literatura e de Estética (a teoria do romance). Trad. Aurora F. Bernardini et alii. 3.ed. São Paulo, UNESP, 1993.

---------- A Poética de Dostoievski. Trad. Paulo Bezerra. Rio de Janeiro, ForenseUniversitária, 1981.

BENJAMIN, Walter. Magia e Técnica, Arte e Política. Trad. Sérgio P. Rouanet. 6.ed. São Paulo, Brasiliense, 1993.

Reflexões: A Criança O Brinquedo A Educação. São Paulo, Summus, 1984.

BELEZA, Newton. Subsídios para julgamento de uma obra de arte. Rio de Janeiro, EMEBE, 1978.

BetTelhein, Bruno. A Psicanálise dos Contos de Fadas. Trad. Arlene Cardoso. 7.ed. São Paulo, Paz e Terra, 1988.

BERGSON, Henri. O Riso. Ensaio Sobre a Significação do Cómico. Lisboa, Relógio D’Água, 1991.

Boletim dos Ilustradores. Ano I, nº 0. Rio de Janeiro, Julho de 1984.

BOUCIER, Paul. A História da Dança no Ocidente. São Paulo, Martins Fontes, 1987.

BRAGA, Teófilo. Contos Tradicionais do Povo Português. Vol.I. Lisboa, Dom Quixote, 1994.

BUSSELLE, Michael. Tudo Sobre Fotografia. Trad. Léa A. Tarsha. São Paulo, Círculo do Livro, 1977. 
CAMARGO, Luís. Ilustração do Livro Infantil. Belo Horizonte, Lê,1995.

Ilustração e Poesia. Tradução, Traição ou Diálogo de Linguagem. Internet, 03 de Maio de 1999.

--------- Poesia Infantil e Ilustração: estudo sobre Ou Isto ou Aquilo de Cecília Meireles. Dissertação apresentada ao Instituto de Estudos da Linguagem da Universidade de Campinas. Campinas, 1998.

CAMPOS, Haroldo. Metalinguagem - Ensaios de Teoria e Crítica Literária. 3.ed. São Paulo, Cultrix, 1974.

CASCUDO, Luis da Camara. Contos Tradicionais do Brasil. Belo Horizonte, Itatiaia, 1986.

Literatura Oral no Brasil. 3.ed. Belo Horizonte. Itatiaia, 1984.

COELHO, Adolpho F. Noções de Litteratura Antiga e Medieval Como Introducção a Litteratura Portugueza. Porto, Universal, 1881.

COELHO, Nelly Novaes. Literatura e Linguagem. Introdução Aos Estudos Literários. São Paulo, Quíron, 1974.

A Literatura Infantil. 4.ed. rev. São Paulo, Quíron, 1987.

Panorama Histórico. 4.ed. ver. São Paulo, Ática, 1991.

COHN, Norman. Na Senda do Milênio. Milenaristas Revolucionários e Anarquistas Místicos da Idade Média. Trad. Fernando Neves; António Vasconcelos. Lisboa, Presença, 1980.

Contos de Grimm. Trad. Maria José U. Alves de Lima. Ilustr. Janusz Grabianski. São Paulo, Melhoramentos, 1968.

DELUMEAU, Jean. História do medo no Ocidente. Trad. Maria Lucia Machado. São Paulo, Companhia das Letras, 1993.

DONIS, A. Donis. Sintaxe da Linguagem Visual. Trad. Jefferson L. Camargo. São Paulo, M. Fontes, 1991.

ELIADE, Mircea. O Sagrado e o Profano. Trad. Rogério Fernandes. Lisboa, Livros do Brasil, 1956.

FERRARA, Lucrécia d’Alessio. Leitura sem palavras. 3.ed. São Paulo, Ática, 1993. 
FERREIRA, Aurélio B. de Holanda. Novo Dicionário Aurélio da Língua Portuguesa. 2.ed. rev. Rio de Janeiro, Nova Fronteira, 1986.

Folha de S. Paulo. Editora Mais. Pág. 06. São Paulo, 12 de Janeiro de 1977.

FRANCASTEL, Pierre. Pintura e Sociedade. Trad. Elcio Fernandes. São Paulo, Martins Fontes, 1990.

FRANCO, Hilário, Jr. Peregrinos, Monges e Guerreiros. Feudo-Clericalismo e Religiosidade em Castela Medieval. São Paulo, Hucitec, 1990.

FRANZ, Marie Louise Von. A interpretação Dos Contos De Fada. Trad. Maria Elci S. Barbosa. São Paulo, Paulinas, 1990.

O Feminino nos Contos de Fadas. Trad. Regina G. de Agostino. Rio de Janeiro, Vozes, 1995.

GILSON, Etienne. A Filosofia na Idade Média. Trad. Eduardo Brandão. São Paulo, Martins Fontes, 1998.

GÓES, Lúcia Pimentel. Em busca da matriz. A literatura infantil e juvenil Portuguesa, suas peculiaridades e evolução das origens à atualidade. Tese de Doutorado apresentada ao Departamento de Letras Clássicas e Vernáculas. São Paulo, FFLCH-USP, 1989. 2v.

A Aventura da Literatura para Crianças. São Paulo, Melhoramentos, 1991.

-Olhar de Descoberta. Ilustração Eva Furnari. São Paulo, Mercuryo, 1996.

GOFF, Jacques Le. O Imaginário Medieval. Trad. Manuel Ruas. 3.ed. Portugal, Estampa, 1994.

HUIZINGA, Johan. Homo Ludens. Trad. João P. Monteiro. 2.ed. São Paulo, Perspectiva, 1980.

IAN, Morris. Death Ritual and Social Structure in Classical Antiquity. England, Cambridge University Press, 1992.

JAKOBSON, Roman. Lingüística e Comunicação. Trad. Isidoro Blikstein e José P. Paes. 2. ed. São Paulo, Cultrix, s.d. 
JENSEN, Ad. E. Mito y culto entre pueblos primitivos. 3.ed. Trad. Carlos Gerhart, México, Fondo de Cultura Economica, 1986.

JOLLES, André. Formas Simples. Trad. Álvaro Cabral. São Paulo, Cultrix, 1976.

JOLY, Martine. Introdução à Análise da Imagem. Trad. Marina Appenzeller. São Paulo, Papirus, 1994.

LAGO, Angela. 10 Advinhas Picantes. Belo Horizonte, RHJ, 1990.

Charadas Macabras. Belo Horizonte, Formato, 1994.

Indo Não Sei Aonde Buscar Não Sei o Quê. Belo Horizonte, RHJ, 2000.

Sua Alteza A Divinha. 11.ed. Belo Horizonte, RHJ, 1990.

Literatura Arte Educação. Intencionalidades da Ilustração. São Paulo, 1990.

LOWENFELD, Viktor; BRITTAIN, W. Lambert. Desenvolvimento da Capacidade Criadora. Trad. Álvaro Cabral. São Paulo, Mestre Jou, 1977.

LEONE, Eduardo; MOURÃO, Maria Dora. Cinema e Montagem. Série Princípios. São Paulo, Ática, 1987.

KANDINSKY, Wallily. Do Espiritual na arte e na pintura em particular. Trad. Álvaro Cabral. 2.ed. São Paulo, Martins Fontes, 1996.

MACEDO, José Rivair. Riso, Cultura e Sociedade na Idade Média. São Paulo, Unesp, 2000

MACHADO, Arlindo. O Desafio das Poéticas Tecnológicas. São Paulo, Edusp, 1993.

MACHADO, Irene A. A voz e o Romance. A Prosaica Dialógica de M. Bakhtin. Rio de Janeiro, Imago, 1995.

MARTINS, Antonio. Arthur Azevedo: A palavra e o riso. São Paulo, Perspectiva, 1988.

MARWIN, Meyer. Ancient Magic and Ritual Power. N.York, Leiden; E.J.Brill, 1995.

MENDES, Maria dos Prazeres Santos. Monteiro Lobato, Clarice Lispector, Lygia Bojunga Nunes: O Estético em Diálogo na Literatura Infanto-Juvenil. Tese de doutorado apresentada ao Departamento de Comunicação e Semiótica da Universidade Pontifícia Católica de São Paulo. São Paulo, PUC, 1994.

METZ, Christian. Linguagem e Cinema. São Paulo, Perspectiva, 1971. 
MOREIRA, José A.Camarinha. Perspectiva Básica. Lisboa, Alpha, 1973.

NABHAN, Neuza Neif. Mil e Uma Noites e o Saber Tradicional. Tese de Livre Docência apresentada ao Departamento de Letras Clássicas e Vernáculas da Faculdade de Filosofia, Letras e Ciências Humanas. São Paulo, FFLCH, 1986.

OLIVEIRA, Valdevino Soares. Poesia e Pintura. Um Diálogo em Três Dimensões. São Paulo, UNESP, 1998.

PALO, Maria José; OLIVEIRA, Maria Rosa D. Literatura infantil - Voz de Criança. 2.ed. São Paulo, Ática, 1992.

PIDAL, Menéndez Ramón. Poesía Juglaresca Y Juglares. Buenos Aires, Espasa-Calpe Argentina, 1942.

PIRES, Cornelio. Selecta Caipira. São Paulo, Livraria Liberdade, 1929.

PLAZA,Júlio;TAVARES,Mônica. Processos Criativos Com os Meios Eletrônicos:

Poéticas Digitais. São Paulo, Hucitec, 1998.

PORTINARI, Maribel. A História da Dança. Rio de Janeiro, Nova Fronteira, 1987.

PROPP, Vladimir. Comicidade e Riso. Trad. Aurora F. Bernardine „Homero F. de Andrade Série Fundamentos. São Paulo, Ática, 1992.

--------- Morfologia do Conto Maravilhoso. Trad. Jasna P. Sarahan. Rio de Janeiro, Forense-Universitária, 1984.

Morfologia do Conto. Trad. Claude Kahn. 2.ed. Lisboa, Vega

Universidade, 1983.

REIS, Carlos; LOPES, Ana Cristina M. Dicionário de teoria da narrativa. São Paulo, Ática, 1988.

Revista ABIGRAF. Ano XXIII, nº 175. São Paulo, Março/Abril,1998.

ROMERO, Sílvio. Contos Populares do Brasil. Belo Horizonte, Itatiaia, 1985.

SANTAELLA, Lucia. A Teoria Geral dos Signos. São Paulo, Ática, 1995.

O que é a Semiótica. 13.ed. São Paulo, Brasiliense, 1995.

Imagem. Cognição, semiótica, mídia. São Paulo, Iluminuras, 1998.

SANT’ANNA, Affonso Romano. Paródia, Paráfrase \& Cia. Série Princípios, 7.ed. São Paulo, Ática, 2000. 
SANTORO, Antônio Júnior. Breve Análise de uma Obra de Arte. São Paulo, Grafistyl, 1976.

SEVERINO, Antonio Joaquim. Metodologia do Trabalho Científico. 20.ed. São Paulo, Cortez, 1998.

SIMONSEN, Michelle. O Conto Popular. Trad. Luis C. de C. e Costa. São Paulo, Martins Fontes, 1987.

STAM, Robert. Bakhtin. Da Teoria Literária à Cultura de Massa. Trad. Heloísa Jahn. São Paulo, Ática, 1992.

TEIXEIRA, Fausto. Estudos de Folclore. Belo Horizonte, Editorial Panorama, 1949.

TODOROV, Tzvetan. Introdução à Literatura Fantástica. Trad. Maria Clara C. Castello. São Paulo, Perspectiva, 1975.

---------- As Estruturas Narrativas. Trad. Leyla P. Moisés. São Paulo, Perspectiva, 1979.

WILLIAMS, Robin. Design para quem não é designer: noções básicas de planejamento visual. Trad. Laura Karin Gillon. São Paulo, Callis, 1995.

ZUMTHOR, Paul. A Letra e a Voz. Trad. Amálio Pinheiro; Jerusa P. Ferreira. São Paulo, Companhia das Letras, 1993. 